\title{
LOOSENING LIPS TO AVOID SINKING SHIPS: DESIGNING A SHIP COMMUNICATIONS SYSTEM FOR THE BERING STRAIT REGION
}

\author{
Elizabeth Barrett Ristroph, Esq.
}

\begin{abstract}
This article compares systems that regulate ship traffic and communications and discusses the legal requirements for each one. It provides recommendations for a regulatory system for the Bering Strait and its surrounding waters - a remote and ecologically important region that is vulnerable to damage from increasing Arctic ship traffic. In cooperation with its Russian counterpart, the United States Coast Guard could work through the International Maritime Organization to establish a ship reporting system, a ship routing system, and/or vessel traffic services, as well as special areas that would be subject to additional regulatory measures. In designing a system, the Coast Guard should consider the Alaska Eskimo Whaling Commission reporting system already in place for oil and gas vessels in waters off the coast of Alaska.
\end{abstract}




\section{CONTENTS}

1. Background

1.1. Wildlife and Subsistence in the Bering Strait Region

1.2. Navigational Infrastructure in the Bering Strait Region

2. Legal Framework

2.1. Intergovernmental and International Bodies and Legal Regimes

2.1.1. International Maritime Organization

2.1.2. Convention on the Law of the Sea

2.1.3. Convention for the Safety of Life at Sea

2.1.4. Convention for the International Regulations for Preventing Collisions at Sea

2.1.5. Convention for the Prevention of Pollution from Ships

2.1.6. Convention on Standards of Training, Certification and Watchkeeping for Seafarers

2.1.7. International Convention on Maritime Search and Rescue

2.1.8. Arctic Council

2.2. Bilateral Treaties Relevant to the Bering Strait Region

2.3. United States Law

2.3.1. Ports and Waterways Safety Act

2.3.2. Navigation Safety Regulations

2.3.3. 2010 U.S. Coast Guard Authorization Act

2.3.4. National Security Policy

2.3.5. White House and Coast Guard Strategies for the Arctic Region

2.3.6. Endangered Species Act and the Marine Mammal Protection Act

2.4. Alaska Law

3. Ship Communications Systems that Could Be Used in the Bering Strait Region

3.1. Ship Reporting System

3.2. Ship Routing System

3.3. Vessel Traffic Service

3.4. Aids to Navigation

3.5. Tracking Technology

3.5.1. Long Range Identification and Tracking

3.5.2. Automated Identification System

3.5.3. Vessel Monitoring Systems for Fisheries

3.6. Notice of Arrival

3.7. Special and Protected Areas

3.7.1. Special Areas

3.7.2. Particularly Sensitive Sea Areas

4. Examples of Ship Regulatory Systems in Place

4.1. Torres Strait-Ship Reporting System, Vessel Traffic Service, and Long Range Tracking Identification System

4.2. United States East Coast-Ship Reporting System, Ship Routing 
System, and Long Range Tracking Identification System

4.3. Northern Canada-Ship Reporting System and Vessel Traffic Service

4.4. Puget Sound/Juan de Fuca Region-Vessel Traffic Service

4.5. Alaska Eskimo Whaling Commission Conflict Avoidance Agreement - Ship Reporting System and Routing System

5. Recommendations for Bering Sea Communications System

5.1. Factors to Consider

5.2. Potential Regulatory Tools

5.2.1. Ship Reporting System

5.2.2. Ship Routing System

5.2.3. Vessel Traffic Service

5.2.4. Aids to Navigation

5.2.5. Tracking Systems

5.2.6. Designation of Areas with Special Regulations

5.2.7. Ice Patrol

5.2.8. Marine Pilotage

6. Conclusion

Appendix 1: Comparison of Systems Used to Regulate Ships

Appendix 2: Outline of Possible Ship Reporting System for Bering

Strait Region

Appendix 3: Navigational Aids in the Bering Strait Region 


\section{INTRODUCTION}

The Bering Strait Region ${ }^{1}$ is critically important for two reasons. First, as the only link between the Pacific Ocean and the Arctic Ocean, it is a major highway for arctic shipping. ${ }^{2}$ Second, it supports some of the most unique wildlife in the world, which in turn has supported a subsistence culture for more than a thousand years. ${ }^{3}$

The number of commercial vessels traversing the Bering Strait Region and the Arctic Ocean has increased significantly in the past few years. ${ }^{4}$ The upward trend will likely continue as melting ice makes the

* 1711 East West Road, Honolulu, Hawaii 96848. E. Barrett Ristroph serves as Arctic Program Representative for the Wilderness Society. She wrote this Article through the support of the World Wildlife Fund's (WWF) Bering Strait Shipping Project, which aims to protect the environment and subsistence activities in the Bering Strait Region, identify the best measures for ships passing through the region, and encourage the United States government to adopt these measures. Barrett would like to thank WWF U.S. Arctic Field Program Director Margaret Williams along with WWF staff members Verner Wilson and Elena Agarkova for their contributions to this article.

1. For purposes of this article, the "Bering Strait Region" refers to the marine area between North America and Asia from roughly 63o and 69o north latitude, consisting of the northern Bering Sea, the Bering Strait, and the southern Chukchi Sea. Andrew Hartsig et al., Arctic Bottleneck: Protecting the Bering Strait Region from Increased Vessel Traffic, 18 OCEAN \& COASTAL L.J. 35, 37 (2012-13). The region extends from St. Lawrence Island and the northern Bering Sea north through the Bering Strait to the southern Chukchi Sea and Cape Lisburne. $I d$. The Bering Strait itself is approximately fifty-three miles and 180 feet deep. See Rebecca Woodgate et al., Bering Strait: Pacific Gateway to the Arctic, WASHINGTON.EDU, http://psc.apl.washington.edu/HLD/Bstrait/bstrait.html (last visited Nov. 2, 2013, archived at http://perma.cc/K9CE-RRV2).

2. Arctic Council, Arctic Marine Shipping Assessment 2009 Report 18 (2009) [hereinafter AMSA REPORT].

3. See id. at 106 (discussing indigenous marine use); Port Access Route Study: In the Bering Strait, 75 Fed. Reg. 68568 (Nov. 8, 2010) (to be codified at 33 C.F.R. pt. 167) [hereinafter Bering Strait PARS]; CENTER FOR BIOLOGICAL DiVERSITY - EARTHJUSTICE Friends of the EARTh - OCEANA PACIFIC ENVIRONMENT - WORLd WildLIFE Fund, Comment Regarding Port Access Route Study in the Bering Strait(75 FR 68568) 912 (2011), archived at http://perma.cc/D3MY-2W5R [hereinafter WWF PARS COMMENTS] (discussing the ecological importance of the Bering Strait); THOMAS L. LAUGHLIN ET AL., WORKSHOP REPORT: IUCN/NRDC/UAF WORKSHOP to IDENTIFY SEVERAL Viable Options For the Protection of ECological AND BiologicAlly SignificANT AREAs (EBSAs) From the Possible Negative Effects of Shipping and Other Maritime Activities in the Bering Strait Region, Nome, Alaska, June 26-28, 2012 9-10 (2012) [hereinafter Nome WORKSHOP REPORT] (describing ecological characteristics and subsistence use of the region).

4. Alaska State Legislature, Findings \& Recommendations of the Alaska NORTHERN WATERS TASK FORCE 14 (2012), archived at http://perma.cc/Q8C7-AC7V [hereinafter NWTF Report] (estimating 6000 vessels operating in or transiting through Arctic waters in 2006; estimating 7000 vessels in 2011); AMSA REPORT, supra note 2, at 4 (reporting 6000 vessels passing through Arctic waters during 2004); WWF, Arctic and Bering Strait Traffic Analysis (2011) (on file with author) (reporting 277 transits through the Bering Strait in 2009 and 513 in 2010); United States Coast Guard Arctic Strategy 5 
Arctic more accessible. ${ }^{5}$ Increased traffic brings more underwater ship noise $^{6}$ and a greater potential for pollution, oil spills, ${ }^{7}$ and collisions between ships and marine mammals. ${ }^{8}$ As of this writing, there is no system in place to minimize the risk of shipping accidents and the likelihood of damage to the region's wildlife and subsistence resources.

This Article analyzes the ship communications systems available under international and United States law for regulating Bering Strait traffic, including ship reporting systems, ship routing systems, vessel traffic services, and other communication systems. It considers the Alaska Eskimo Whaling Commission reporting system used to avoid conflict between oil and gas vessels and subsistence whaling, as well as systems operating in other parts of the world.

\section{BACKGROUND}

\subsection{Wildlife and Subsistence in the Bering Strait Region}

Positioned as the junction between the Pacific and the Arctic, the Bering Strait Region benefits from nutrient-rich waters that flow from the northern Bering Sea into the Chukchi Sea. ${ }^{9}$ These waters support many birds, fish, and marine mammals, including a number of endangered species. ${ }^{10}$ Approximately 10 million seabirds nest and forage in the Bering

(2013), archived at http://perma.cc/KSA3-QCDD [hereinafter USCG ARCTIC STRATEGY] (from 2008 to 2012, traffic through the Bering Strait increased by 118 percent).

5. AMSA REPORT, supra note 2, at 5 ("Offshore hydrocarbon developments may lead to increased marine traffic in the Bering Strait region"), 89, 136 (referring to melting ice); NWTF REPORT, supra note 4, at 2, 14 (noting diminishing ice and that many nations are actively building more ships designed to operate in Arctic waters); WWF PARS COMMENTS, supra note 3, at 13-15 (discussing current and proposed oil and gas and mining activities in the Arctic region and predicting increased vessel traffic in the region); see Hartsig et al., supra note 1, at 35 (discussing effect of climate change on Bering Strait region and Arctic).

6. See, e.g., Marla M. Holt, Marine Mammal Ecology, Paper presented at the 17th Annual Endangered Species Act Seminar, Seattle, Wash. (Jan. 29, 2010) (discussing effects of exposure to underwater sound on marine mammals).

7. AMSA RePORT, supra note 2, at 106; see also MARINE MAMMAL COMMISSION, Comment Regarding Port Access Route Study in the Bering Strait (75 FR 68568) 2 (2011), archived at http://perma.cc/QTP8-HKPN [hereinafter MMC PARS COMMENTS] (discussing impacts of vessel traffic on whales and potential threats to marine mammals).

8. See AMSA REPORT, supra note 2, at 106 (ship strikes of whales and other marine mammals are of concern in areas where shipping routes coincide with seasonal migration and areas of aggregation); Hartsig, et al., supra note 1, at 14 (citing Randall Reeves et al., Implications of Arctic Industrial Growth and Strategies to Mitigate Future Vessel and Fishing Gear Impacts on Bowhead Whales, 36 MARINE POLICY 454, 458-459 (2012)).

9. See Audubon Society, Comment Regarding Port Access Route Study in the BERING STRAIT (75 FR 68568) 1 (Sept. 6, 2011) [hereinafter AudubON COMMENTs], archived at http://perma.cc/7VGM-KKCT [hereinafter AUDUBON COMMENTs]

10. See 50 C.F.R. $\S 17.11$ (2011) (referring to species listed as threatened or endangered under the Endangered Species Act, including bowhead whales, polar bears, Steller sea lions, 
Strait Region. ${ }^{11}$ Hundreds of thousands of marine mammals of several species migrate through the strait in both spring and fall, including Pacific walrus; ringed, ribbon, spotted, and bearded seals; polar bears, and beluga, gray and bowhead whales. ${ }^{12}$ Almost the entire Bering-Chukchi-Beaufort stock of bowhead whales - some 10,500 individuals - moves through the Bering Strait twice each year. ${ }^{13}$ The bowhead whale ${ }^{14}$ and other subsistence resources support indigenous coastal communities belonging to Iñupiaq, Central Yupik, and Siberian Yupik cultural groups in the Bering Strait Region and on the North Slope. ${ }^{15}$ Residents of these communities have relied on the region's resources for over a thousand years. ${ }^{16}$

Subsistence resources provide more than just nutrition-they define and establish the sense of family and community. ${ }^{17}$ Subsistence is closely linked with traditional values in Bering Strait native communities, including sharing, passing down knowledge regarding the resources, respect for elders, self-esteem for a successful harvest, and gratitude. ${ }^{18}$ As stated in one study, "No other set of activities provides a similar moral foundation for continuity between generations."19

\subsection{Navigational Infrastructure in the Bering Strait Region}

Maritime infrastructure in the Bering Strait region is limited, with

and a number of bird species); Melanie A. Smith, Place-Based Summary of the Arctic MARINE SYNTHESIS 3 (2011) (referring to forty species of birds as well as several endangered or threatened seal and whale species in the Bering Strait region); NORTH PACIFIC FISHERY Management Council, Fishery Management Plan for Fish Resources of the Arctic MANAGEMENT AREA 83-85 (2009) (showing essential habitat for Arctic cod, saffron cod, and snow crab).

11. Audubon COMments, supra note 9, at 2 .

12. Audubon COMments, supra note 9 , at 1 .

13. Hartsig et al., supra note 1 , at 41 . While much of the fall and winter bowhead whale traffic occurs along the Russian side of the Bering Strait, the northward spring migration of the species takes place through U.S. Bering Strait waters, where vessel traffic levels are increasing. WWF PARS COMMENTS, supra note 3, at 17.

14. The bowhead whale is a species with significant subsistence importance. See Overview of the Alaska Eskimo Whaling Commission, ALASKA ESKIMO WHALING COMMISsION, http://www.bluediamondwebs.biz/Alaska-aewc-com/aboutus.asp (last visited Nov. 2, 2013, archived at http://perma.cc/989N-HKZN) (discussing the nutritional and cultural importance of the bowhead whale to Iñupiat and Yupik Eskimos).

15. AMSA REPORT, supra note 2, at 106.

16. AMSA REPORT, supra note 2, at 106.

17. Don Callaway et al., Implications of Global Change in Alaska and the Bering Sea Region, Subsistence Fisheries 102 (Gunter Weller \& Patricia A. Anderson eds., 1998), archived at http://perma.cc/RW8F-3WU5; see also Elizabeth B. Ristroph, Alaska Tribes' Melting Subsistence Rights, 1 Ariz. J. Envtl. L. \& PoL'Y 47, 49-51 (2010) (describing the value of subsistence to North Slope communities).

18. Callaway ET Al., supra note 17, at 97.

19. CAllaway ET AL., supra note 17, at 97. 
only three major ports on the Alaskan side.$^{20}$ None of the Alaskan ports is a deep-water port capable of handling large vessels, ${ }^{21}$ although the City of Nome has been considering the construction of a deep-water port. "There are no formally established vessel routing measures in the Bering Strait region." ${ }^{23}$ Although a standard Global Positioning System (GPS) fully covers the region, the high latitudes in the region may compromise its accuracy, and there is no differential GPS coverage. ${ }^{24}$

The U.S. Coast Guard maintains very high frequency (VHF) FM sites in the Bering Sea and high frequency (HF) radio guard for emergency calls, but HF coverage of the Arctic is poor. ${ }^{25}$ There is local VHF coverage at certain villages within or near the region, including Nome, St. Lawrence Island, Kivalina, Wales, Kotzebue, Barrow, Point Lay, Point Hope, and Wainwright, and high frequency (HF) National Oceanic and Atmospheric Administration (NOAA) radios at Barrow and Kotzebue. ${ }^{26}$ Outside of VHF and HF marine coverage, the U.S. Coast Guard relies on satellite

20. These include Nome, Kotzebue, and the DeLong Mountain Terminal. AMSA REPORT, supra note 2, at 108. Major Russian ports in the area are Provideniya, Anadyr, and Egvekinot. AMSA REPORT, supra note 2, at 108.

21. AMSA REPORT, supra note 2, at 175 (explaining that the closest U.S. deep-water port is Dutch Harbor/Unalaska in the southern Bering Sea, while on the Russian Federation side, the nearest deep-water port is Provideniya). Loading and unloading operations at Kotzebue and the DeLong Mountain Terminal are accomplished through lightering (transferring cargo from a larger, deep-draft vessel to smaller, shallower-draft vessels capable of entering shallow-draft ports). NORTHERn ECONOMICS, AlASKA REGIONAL PORTS: Planning for Alaska's Regional Ports and Harbors Final Report 35 (2011), available www.dot.state.ak.us/stwddes/desports/assets/pdf/regionalports_finalreport0111.pdf.

22. City of Nome, Comment Regarding Port Access Route Study in the Bering StRAIT (75 FR 68568) 2 (Feb. 23, 2011), archived at http://perma.cc/R6V4-E3XH ("the Port of Nome is currently reviewing design options, and seeking associated funding and support necessary to extend our facility to deeper water thereby providing the necessary Deepwater Port for the Northwest Arctic Region.")

23. AMSA REPORT, supra note 2, at 109.

24. AMSA REPORT, supra note 2, at 109; NDGPS General Information, UNITED STATES COAST GUARD, http://www.navcen.uscg.gov/?pageName=dgpsMain (last visited Feb. 15, 2014, archived at http://perma.cc/N2ND-5H52) (explaining that the positional error of a differential GPS position is 1 to 3 meters, greatly enhancing harbor entrance and approach navigation in comparison to standard GPS).

25. AMSA REPORT, supra note 2, at 109.

26. AMSA REPORT, supra note 2, at 164 (referring to VHF in Barrow, Nome, and Kotzebue). The Alaska Eskimo Whaling Commission Conflict Avoidance Agreement refers to VHF in each of the North Slope villages subject to the agreement, including Nuiqsut, Kaktovik, Barrow, Wainwright, Point Lay, and Point Hope. See 2012 Open Water Season Programmatic Conflict Avoidance Agreement $\$ 205$ (Mar. 1, 2012) [hereinafter CAA]. In 2012, AEWC added additional communication centers on St. Lawrence Island, Kivalina, and Wales. E-mail from Earl Comstock, AEWC Counsel to author (Oct. 2, 2012) (on file with author). 
communications. ${ }^{27}$ Vessel tracking through a satellite-based system (Long Range Tracking and Identification) and a VHF system (Automatic Identification System) are available in the Bering Strait and surrounding region. $^{28}$

There is no permanent U.S. Coast Guard presence in the Bering Sea region, ${ }^{29}$ and the closest Coast Guard stations are hundreds of miles away in Unalaska/Dutch Harbor ${ }^{30}$ and Kodiak. ${ }^{31}$

The Coast Guard has only two functioning icebreakers, ${ }^{32}$ though sea ice is generally present along the Bering Strait for at least half of the year. ${ }^{33}$ There are only three Coast Guard-maintained navigational aids at the Bering Strait along the north side of the Seward Peninsula into Kotzebue Sound, ${ }^{34}$ and one aid to navigation tower near Point Hope ${ }^{35}$ (roughly 200

27. AMSA REPORT, supra note 2, at 164 .

28. Personal Communication with Ed Haney, Maritime Specialist, Marine Exchange of Alaska (Oct. 2, 2012).

29. See, e.g., Nuka Research \& Planning Group, LlC., Oil Spill Prevention and Response in the U.S. ARCtic Ocean: UneXamined Risks, Unacceptable Consequences 23 (2010), archived at http://perma.cc/EU95-E8FM (noting that the closest Coast Guard air station to the Arctic is in Kodiak).

30. The Unalaska/Dutch Harbor station is a Marine Safety Detachment of the Anchorage Sector of the Coast Guard's Seventeenth District. Personal Communication with Marine Safety Detachment Supervisor Lt. James Fothergill (Nov. 8, 2012). It has a permanent presence in Unalaska and has jurisdiction over marine casualty investigations, pollution investigations, and domestic and foreign vessel inspections. Id.

31. Units located in the 17th District, United STATES COAST GuARD, http://www.uscg.mil/d17/units.asp (last visited Feb. 15, 2014, archived at http://perma.cc/343K-QX7G).

32. Brian Moore, Get Serious About the Arctic, USNI News (Aug. 5, 2012), http://news.usni.org/2012/08/05/get-serious-about-arctic, archived at http://perma.cc/MUY6LSLA. The Coast Guard has two non-functioning icebreakers, including the Polar Sea, which is scheduled to be scrapped, and the Polar Star, which is undergoing renovations and should be ready by late 2013. Id.

33. AMSA REPORT, supra note 2, at 106 (explaining that sea ice typically develops along the coasts in October and November and retreats northward from May to July); see also Current Bering Sea Ice Area, The Univ. of Ill. at Urbana-Champaign Polar RESEARCH GROUP, DEP'T OF ATMOSPHERIC SCI., http://arctic.atmos.uiuc.edu/cryosphere/IMAGES/recent365.anom.region.2.html (last visited Feb. 15, 2014, archived at http://perma.cc/EG9E-E5UZ) (showing ice coverage of the Bering Sea in square kilometers); AlASKa CENTER FOR Climate FOR Assessment \& Policy, SEA ICE, archived at http://perma.cc/8TJ7-XCR6 (explaining that sea ice is present along or close to the northern coast for eight to ten months of the year and affects much of the western coastline for at least several months of most years); Community: Diomede, STATE of Alaska, Dep't of Commerce, Community, and Economic Development: Community AND REGIONAL AFFAIRS, http://commerce.alaska.gov/cra/DCRAExternal/community/Details/9770db48-3493-41e4b104-a4f5ea1a723a (last visited Feb. 15, 2014) (the Bering Strait is generally frozen between mid-December and mid-June).

34. AMSA REPORT, supra note 2 , at 109. 
miles north of the Bering Strait).

There is no spill response capability in the vicinity of the Bering Strait. ${ }^{36}$ Since the Bering Strait is considered a remote area under Coast Guard rules, tank vessels may seek alternative compliance to meet the US requirements for oil spill response and financial responsibility. ${ }^{37}$ Vessels may also simply use the Russian side of the international boundary. The Coast Guard has developed oil spill planning, firefighting, and salvage requirements for nontank vessels, but they are not yet in effect. ${ }^{38}$

The Coast Guard is aware of its limitations and making efforts to increase its Arctic presence. In 2010, the U.S. Coast Guard initiated an Alaska Deep Draft Arctic Ports Study for the Bering Strait with the objective of improving maritime traffic regulation and reducing marine casualties. $^{39}$ The study may recommend the establishment of a traffic separation scheme, the creation of a precautionary area or area to be avoided, the establishment of a Regulated Navigation Area, or other measures. ${ }^{40}$ Recommendations from the study may lead to domestic rulemaking or a proposal for an International Maritime Organizationestablished regulatory scheme. ${ }^{41}$

Plans for a new icebreaker are underway, though it may take $\$ 1$ billion and a decade to build. ${ }^{42}$ In the meantime, the Coast Guard has

35. Connie Braesch, Day 10: Coast Guard Video of the Year, COAST GuARD COMPASS (Dec. 30, 2010), http://coastguard.dodlive.mil/2010/12/day-10-coast-guard-video-of-theyear-2/, archived at http://perma.cc/92QJ-4UJ3. The Coast Guard installed this tower in 2010. Id.

36. Alaska Dep't of Envtl. Conservation, Div. of Spill Prevention and Response, Comment Regarding Port Access Route Study in the Bering Strait (75 FR 68568) 6 (May 6, 2011), archived at http://perma.cc/WM26-TDGE.

37. Id. at 7; see also FAQ, Alaska Maritime Prevention \& Response Network, www.ak-mprn.org/faq.php, (last visited Feb. 15, 2014, archived at http://perma.cc/AF573X3S) (explaining that the U.S. Coast Guard adopted "The Western Alaska Alternative Planning Criteria" for Oil Tankers and vessels that carry oil as secondary cargo as an alternative option for meeting the Coast Guard's oil spill removal equipment capabilities outlined in the "Oil Pollution Prevention" regulations (33 C.F.R. 155 Subpart D)).

38. See Nontank Vessel Response Plans and Other Vessel Response Plan Requirements, 74 Fed. Reg. 44970 (proposed Aug. 31, 2009) (to be codified at 33 C.F.R. pt. 151, 155, and 160) (proposing rules for nontank response plans).

39. Bering Strait PARS, supra note 3. At the same time, the Alaska Department of Transportation and Public Facilities (DOT\&PF) and the Army Corps of Engineers have been co-sponsoring an Alaska Deep Draft Arctic Ports Study to evaluate potential deep-water port locations. Alaska Dep't of Transp. \& Pub. Facilities/Statewide Design \& Eng'G Serv., ARCTIC PorT STUDY (2013), archived at http://perma.cc/7MG2-X7UL.

40. See Bering Strait PARS, supra note 3. The study was supposed to be completed in late 2012. Bering Strait PARS, supra note 3. As of this writing it is not available.

41. See Bering Strait PARS, supra note 3.

42. Editorial, Scrapping the Polar Sea Stopped While Lawmakers Search for Budgetary Icebreaker, SEATTLE TIMES, June 21, 2012, archived at http://perma.cc/LC6W-XB3G ("Local officials with Vigor Industrial in Seattle, which has worked on both the Polar Star and Polar Sea, put the cost of a new icebreaker at $\$ 800$ million to $\$ 1$ billion; the work takes a 
launched an effort known as Arctic Shield to increase its presence in the Arctic. ${ }^{43}$ In the summer of 2012, the Coast Guard stationed two cutters, two smaller ships, and two helicopters in Barrow, Alaska. ${ }^{44}$ Corpsmen engaged in community outreach and practiced deploying oil skimmers in Arctic waters. $^{45}$

\section{LEGAL FRAMEWORK}

Since a significant portion of the Bering Strait Region is beyond the United States' twelve-mile territorial sea, ${ }^{46}$ federal law alone will not sufficiently protect the region. This Article discusses a range of national, bilateral, and multilateral sources of law that can be applied to the region, including both enforceable "hard" and voluntary "soft" law. While hard law can provide more protection than soft law, it may be difficult to enforce in the remote Bering Strait Region.

Voluntary guidelines or agreements, while unenforceable, may be implemented more quickly with less political capital. ${ }^{47}$ As in the case of hard law, compliance is more likely if ships know they are being monitored. ${ }^{48}$

decade.”). In 2012, Congress appropriated funds to initiate survey and design activities for a new polar icebreaker An Act to authorize appropriations for the Coast Guard for fiscal years 2013 through 2014, and for other purposes. Coast Guard and Maritime Transportation Act of 2012, Pub. L. No. 112-213, 126 Stat. 1560 (2012).

43. See United States CoAst Guard, Arctic Shield 2012, http://www.uscg.mil/d17/docs/Arctic\%20Trifold\%20-\%20120614-2.pdf, archived at http://perma.cc/6K38-CE3F.

44. Hannah Heimbuch, Coast Guard Leaves Arctic for Winter Season, ThE ARCTIC $\begin{array}{lll}\text { SOUNDER, } & \text { Nov. 2012, }\end{array}$ http://www.thearcticsounder.com/article/1245coast_guard_leaves_arctic_for_winter_season, archived at http://perma.cc/ZS8M-29F7.

45. Id.

46. Bering Strait, wORLDATLAS, http://www.worldatlas.com/aatlas/infopage/bering.htm (last visited Mar. 15, 2014, archived at http://perma.cc/V9CH-EUSY).

47. See Nihan Ünlü, Particularly Sensitive Sea Areas: Past Present and Future 8 (2007), archived at http://perma.cc/KV24-4Y6J (suggesting that voluntary guidelines may lead to more positive and significant results than a treaty which is ratified or applied by only a few States); NOME WORKSHOP REPORT, supra note 3, at 17 (voluntary guidelines may be developed more quickly than binding agreements and lend themselves to bilateral agreements).

48. At an August 2012 Bering Strait Region workshop, Coast Guard retiree Ed Page suggested that that the vast majority of vessels comply with voluntary speed restrictions when others vessels are able to monitor their speeds using automated tracking technology. Amelia Cooper, Organizations Prepare for Increased Arctic Shipping 1, Nome Nugget, July 5, 2012, http://www.nomenugget.net/archives/2012/070512nn.pdf, archived at http://perma.cc/LYM4-4D88. In contrast, NOAA biologist Brad Hanson, speaking at the same workshop, said that voluntary measures do not work well, and that better compliance is achieved when someone is watching it all times. $I d$. at 6 . Another example of voluntary compliance is the International Maritime Organization [IMO]-established Area to $\mathrm{Be}$ Avoided near the Olympic Coast National Marine Sanctuary in Washington State. A 


\subsection{Intergovernmental and International Bodies and Legal Regimes}

\subsubsection{International Maritime Organization}

The International Maritime Organization (IMO) is responsible for the safety and security of shipping and the prevention of ship pollution. ${ }^{49}$ It was chartered as the Intergovernmental Maritime Consultative Organization (IMCO) in 1959, when its organic treaty went into effect. ${ }^{50}$ IMCO was the first global international organization with competency over marine affairs and marine environmental protection. It became a specialized agency within the United Nations system in 1982 and changed its name to IMO. ${ }^{51}$ IMO facilitates most international maritime conventions and establishes international rules and standards governing vessel traffic. ${ }^{52}$

IMO developed two sets of voluntary guidelines that are particularly significant for Arctic shipping - the 2002 Guidelines for Ships Operating in Arctic Ice-Covered Waters ${ }^{53}$ and the 2009 Guidelines for Ships Operating in Polar Waters. ${ }^{54}$ The 2002 Guidelines address navigation safety and pollution prevention for Arctic waters beyond the existing requirements in international conventions. ${ }^{55}$ They introduce a system of Polar Classes to differentiate ships' capacities to navigate and operate in Arctic waters,

National Oceanic and Atmospheric Administration report noted that most vessels avoided the area, even though it was established through a voluntary guideline. See GEORGE Galasso, Olympic Coast National Marine Sanctuary Area to be Avoided (ATBA) EducAtion AND Monitoring Program 1-4 (2000), archived at http://perma.cc/9ZKLVS8L. See also Christopher P. Knight, NORDREG Now Mandatory Within the Northwest Passage, Association OF CORPORAte Counsel (Nov. 5, 2010), http://www.lexology.com/library/detail.aspx?g=e10bded7-7e16-40f2-96f8-c65c2df4f756,

archived at http://perma.cc/W96N-63U5 (prior to Canada's creation of mandatory reporting zones in 2010 , virtually all vessels operating in these areas complied with a voluntary reporting scheme, since it allowed access to services such as ice information, routing, icebreaker assistance, and search and rescue response).

49. Introduction to IMO, INTERNATIONAL MARITIME ORGANIZATION, www.imo.org/About/Pages/Default.aspx (last visited Feb. 15, 2014, archived at http://perma.cc/ENQ2-X224).

50. Convention on the International Maritime Organization, Mar. 6, 1948, 9 U.S.T. 621, 289 U.N.T.S. 48.

51. Introduction to IMO, supra note 49.

52. AMSA REPORT, supra note 2, at 50.

53. Oystein Jensen, Fridtjof Nansens Institutt, The imo Guidelines for Ships Operating IN ARCTIC ICE-COVEREd WATERs (2002) [hereinafter 2002 Guidelines].

54. International Maritime Organization [IMO], Guidelines for Ships Operating in Polar Waters, IMO Assembly RES. A.1024 (26) (Dec. 2, 2009) [hereinafter 2009 Guidelines]. The Preamble to the Polar Shipping Guidelines does not specifically revoke the 2002 Guidelines, so the 2002 Guidelines should still apply to the extent they are not inconsistent with the 2009 Guidelines.

55. Ships Operating in Polar Regions, International Maritime Organization, www.imo.org/ourwork/safety/safetytopics/pages/polarshippingsafety.aspx (last visited Feb. 15, 2014, archived at $\mathrm{http}: / /$ perma.cc/N9UB-27LG). 
where Polar Class 1 vessels are capable of operating year-round in all Arctic ice-covered waters. ${ }^{56}$

The 2009 Guidelines are similar in form and content to the 2002 Guidelines, but expand coverage to Antarctic waters. ${ }^{57}$ There are few provisions on communication, but the Guidelines do suggest that all ships be provided with Automatic Identification Systems (AIS). ${ }^{58}$ Also, the Guidelines suggest that all ships be capable of receiving ice and weather information charts and displaying ice imagery. ${ }^{59}$

IMO is now developing a mandatory ${ }^{60}$ Polar Code that was in draft form at the time this Article was published. ${ }^{61}$ The Polar Code is intended to "cover the full range of design, construction, equipment, operational, training, search and rescue and environmental protection matters relevant to ships operating in the inhospitable waters surrounding the two poles." ${ }^{62}$ The form and content will likely be similar to the 2009 Guidelines, ${ }^{63}$ and will probably not change the jurisdiction of coastal states or cover ships' routing. ${ }^{64}$

\subsubsection{Convention on the Law of the Sea}

The 1982 United Nations Convention on the Law of the Sea (UNCLOS $^{65}$ serves as a framework for international agreements and regulations concerning vessels. ${ }^{66}$ Although UNCLOS was never ratified by

56. 2002 GuIDELINES, supra note 53, at P-2.7, G-3.18.

57. 2009 Guidelines, supra note 54, at G-3.2, (defining polar waters to include both Arctic and Antarctic waters).

58. 2009 Guidelines, supra note 54, at 12.7; 2002 GUIDELINES, supra note 53, at 12.7.

59. 2009 Guidelines, supra note 54, at 12.11.1-12.11.2; 2002 GuIDELINES, supra note 53, at 12.12.1-12.12.2.

60. The IMO working group developing the Polar Code agreed that it should be made mandatory under SOLAS and/or MARPOL. See Meeting Summary: Sub-Committee on Ship Design and Equipment (DE), 53rd session: 22-26 Feb. 2010, InTERNATIONAL MARITIME Organization, www.imo.org/MediaCentre/MeetingSummaries/DE/Pages/DE-53rdSession.aspx (last visited Feb. 15, 2014, archived at http://perma.cc/9WF3-RPPT).

61. Cooper, supra note 48, at 6; NWTF REPORT, supra note 4, at 14.

62. Meeting Summary: Sub-Committee on Ship Design and Equipment (DE), supra note 60.

63. PowerPoint Presentation, Ove Tautra, Norwegian Maritime Directorate The Polar Code Negotiations-Power and Compromises (stating that the current draft of the Polar Code has the same chapters as the Guidelines, although in another order, and some chapters may be omitted; chapter content is based on the Guidelines).

64. Id.

65. Convention on the Law of the Sea, Dec. 10, 1982, 1833 U.N.T.S. 3 [hereinafter UNCLOS]. UNCLOS came into force in 1994. Id.

66. See Craig H. Allen, Revisiting the Thames Formula: The Evolving Role of the International Maritime Organization and Its Member States in Implementing the 1982 Law of the Sea Convention, 10 SAN DIEGO INT'L L.J. 265, 274 n.36 (2009) (collecting sources suggesting that UNCLOS was designed to be applied in conjunction with other international agreements and customary international law). 
the United States, much of it may be viewed as international customary law. ${ }^{67}$

UNCLOS divides responsibility for navigation safety, environmental protection, and other matters between coastal states (those bordering the waters where a vessel passes), the port state (the vessel's destination), and the vessel's flag state (the state with which the vessel is registered) ${ }^{68}$ The flag state has primary responsibility for controlling the vessel's navigation, ${ }^{69}$ while the coastal state must provide notice of any known navigational dangers within its twelve-mile territorial sea. ${ }^{70}$ All states have some responsibility for controlling pollution and protecting the environment. $^{71}$

A coastal state can exercise full sovereignty over ships in its internal waters and set conditions for entry into its ports. ${ }^{72}$ A coastal state may

67. See United States v. Kun Yun Jho, 465 F. Supp. 2d 618, 632 (E.D. Tex. 2006) ("The United Nations Convention on the Law of the Sea (UNCLOS) is a codification of customary international law negotiated under the auspices of a United Nations conference.") rev'd on other grounds, 534 F.3d 398 (5th Cir. 2008); United States v. Royal Caribbean Cruises, Ltd., 11 F. Supp. 2d 1358, 1372 (S.D. Fla. 1998) (citing UNCLOS); Proclamation No. 5030, 48 Fed. Reg. 10,605 (Mar. 10, 1983) (except for its Part XI, the LOS Convention is already part of customary international law and in that way creates rights and obligations for the United States); United States Oceans Policy, 19 Weekly Comp. Pres. Doc. 383 (Mar. 10, 1983), archived at http://perma.cc/X8AK-88YU (recognizing that the UNCLOS navigation and overflight provisions confirm existing maritime law and fairly balance the interest of all states).

67. The Coast Guard identifies UNCLOS as "“among the most important treaties for [the] protection of the marine environment."' Benedict S. Gullo, The Illegal Discharge of Oil on the High Seas: The U.S. Coast Guard's Ongoing Battle against Vessel Polluters and a New Approach toward Establishing Environmental Compliance, 209 MiL. L. REV. 122, 141 (Fall, 2011) (alteration added) (citing COAST GUARD MARITIME LAW ENFORCEMENT MANUAL, COMDTINST M16247, $\uparrow 9$. B.1 (2010)).

68. UNCLOS, supra note 65, art. 92. Under article 92, a ship generally must sail under the flag of one state only (the ship's flag state). UNCLOS, supra note 65, art. 92. There must exist a genuine link between the flag state and the ship, as the ship will have the nationality of that state. See UNCLOS, supra note 65, art. 91.

69. UNCLOS, supra note 65, at art. 94(3)(c) (requiring the flag state to ensure safety at sea by measures that include "the maintenance of communications and the prevention of collisions").

70. UNCLOS, supra note 65, art. 24(2).

71. UNCLOS, supra note 65, art. 194(1) (requiring states to take "individually or jointly as appropriate, all measures consistent with this Convention that are necessary to prevent, reduce and control pollution of the marine environment from any source" with regard to vessels and other marine installations and devices). Section 5 of UNCLOS, International Rules and National Legislation to Prevent, Reduce and Control Pollution of the Marine Environment (articles 207-212) generally assign pollution control responsibilities to all states, with some responsibilities and rights specific to coastal states. UNCLOS, supra note 65, art 207-212. Article 192 imposes on all states an obligation to preserve and protect the environment. UNCLOS, supra note 65, art. 192.

72. UNCLOS, supra note 65 , art. 2 (describing sovereignty of coastal state), art. 8 
prescribe unilateral standards regarding navigation, pollution control and other matters for its territorial sea, although these standards generally cannot apply to "the design, construction, manning or equipment of foreign ships unless they are giving effect to generally accepted international rules or standards." ${ }^{, 73}$ Nor can standards impede the right of innocent passage. ${ }^{74}$

UNCLOS article 22 allows a coastal state to establish sea lanes and traffic separation schemes in its territorial sea and require ships to follow these lanes or schemes, so long as the coastal state takes into account (a) any relevant $\mathrm{IMO}^{75}$ recommendations; (b) any channels customarily used for international navigation; (c) the special characteristics of particular ships and channels; and (d) the density of traffic. ${ }^{76}$

Coastal state control is more limited beyond the territorial sea ${ }^{77}$ and in "international straits." Although UNCLOS did not define "international strait," the term was discussed extensively in the Corfu Channel case decided by the International Court of Justice in $1949 .^{78}$ The court indicated that international straits are distinguished by geographical and functional criteria, with "the decisive criterion" being the strait's "geographical situation as connecting two parts of the high seas and the fact of its being

(defining internal waters and explaining that the right of innocent passage exists only in internal waters that previously had not been considered as such). Article 25(2) recognizes the coastal state's right to prescribe conditions for entry into its internal waters and ports and to take necessary steps to prevent a breach of those conditions by foreign vessels. UNCLOS, supra note 65, art. 25(2); see also UNCLOS, supra note 65, arts. 38 and 211(3) (referring to the conditions of entry of a port state); 33 U.S.C. $\$ 1228$ (1990) (providing authority for the Secretary to prescribe conditions for entry to ports in the United States); 33 U.S.C. $\$ 1223(d)$ (1990) (generally exempting foreign vessels in innocent or transit passage from the Ports and Waterways Act except where authorized by a treaty or where the vessel is destined for or departing from a port or place subject to the jurisdiction of the United States); 33 C.F.R. $\S \S 160.103(\mathrm{c}), 164.02$ (providing exemptions for certain foreign vessels in innocent or transit passage).

73. UNCLOS, supra note 65, art. 21(2).

74. See UNCLOS, supra note 65, art. 17 (ships of all states enjoy the right of innocent passage through the territorial sea).

75. The Convention does not directly refer to IMO, although its references to "competent international organizations" have been interpreted to refer to IMO in the context of environmental protection, equipment and design standards, and vessel traffic. RESTATEMENT (THIRD) OF ForEign RELATIONS LAW $§ 513 \mathrm{cmts}$. j \& d (1987) (noting that the "competent international organization" is "principally the IMO"); see also George K. Walker, Defining Terms in the 1982 Law of the Sea Convention IV: The Last Round of Definitions Proposed by the International Law Association (American Branch) Law of the Sea Committee, 36 CAL. W. INT'L L.J. 133, 167 (2005).

76. UNCLOS, supra note 65, art. 22.

77. See UNCLOS, supra note 65, art. 211(4). For example, a coastal state may unilaterally adopt pollution control laws that govern foreign vessels within the coastal state's territorial sea, as long as the laws do not impair the right of innocent passage. A coastal state may also adopt laws within its 200-mile exclusive economic zone (EEZ) under article 211(5), but these laws must be consistent with generally accepted international rules. UNCLOS, supra note 65, art. 211(5).

78. See The Corfu Channel Case, Judgment, 1949 I.C.J. 4 (Apr. 9). 
used for international navigation."79 Given that the Bering Strait is the only place connecting the Arctic and Pacific Oceans, it is used by most international vessels crossing the Arctic, and it is not within the internal waters of any one country, it is likely to be an international strait. ${ }^{80}$

Vessels in international straits have a right of "transit passage," which is the exercise of "the freedom of navigation and overflight solely for the purpose of continuous and expeditious transit of the strait." ${ }^{81}$ In general, the laws and regulations that a coastal state may adopt with respect to transit passage through an international strait are more limited than those relating to innocent passage. ${ }^{82}$ UNCLOS allows coastal states regulating transit passage to adopt laws relating to safety of navigation, vessel traffic, pollution control, fishing, and customs, fiscal, immigration, and sanitary issues, ${ }^{83}$ but these laws and regulations may "not discriminate in form or in fact among foreign ships" and cannot "have the practical effect of denying, hampering or impairing the right of transit passage." $" 84$

Since coastal states along an international strait cannot impede, impair, hinder, deny, or suspend the right of transit passage, ${ }^{85}$ they are limited in their abilities to enforce their regulations against vessels in transit. But under article 233 they can "take appropriate enforcement measures" 86 in the event transiting vessels violate the regulations in a manner "causing or threatening major damage to the marine environment of

79. See id., 28 (Merits).

80. See UNCLOS, supra note 65, Part III, arts. 34-45 (discussing transit passage). It is generally acknowledged that the Bering Strait meets the UNCLOS definition of an international strait. See, e.g., AMSA REPORT, supra note 2, at 106 ("The Bering Strait is a narrow international strait ...”) (alteration added); Jon M. Van Dyke, Transit Passage Through International Straits, in The Future of OcEAN Regime-BuILding: Essays IN Tribute to Douglas M. Johnston 178 (Aldo E. Chircop, Ted McDorman, Susan Rolston eds., 2009) (referring to the Bering Strait as one of several "key" international straits).

81. UNCLOS, supra note 65, art. 38(2). Transit passage is similar to innocent passage, but is "free from many of the restrictions implied in innocent passage." RESTATEMENT (THIRD) OF FOREIGN RELATIONS LAW $\S 513 \mathrm{cmt}$. j (1987). For example, a coastal state may temporarily suspend innocent passage through the territorial sea, but it may not suspend transit passage through an international strait. Id. Similarly, submarines must surface in innocent passage, but may remain submerged in transit passage. Id.

82. Restatement (ThiRd) OF Foreign RELATIONS LAW $§ 513 \mathrm{cmt}$. j (1987).

83. UNCLOS, supra note 65, art. 42(1).

84. UNCLOS, supra note 65 , art. 42(2).

85. Van Dyke, supra note 80, at 184 (citing UNCLOS articles 38(1), 42(2) and 44).

86. The Malacca Straits States (Indonesia, Malaysia, and Singapore) have interpreted Article 233 to allow them to take appropriate enforcement measures against ships passing through the Straits that fail to meet the 3.5 meter under-keel clearance requirement which they have established. Van Dyke, supra note 80, at 184; see also ANA G. LÓPEZ MARTín, International Straits: Concept, Classification AND Rules of PAssage 173 (2010) (suggesting that it would be reasonable for a coastal state to impose an execution measure that impedes, hinders, or hampers the right of transit passage but prevents greater damage to the coastal state). 
the straits." ${ }^{87}$

A coastal state can "designate sea lanes and prescribe traffic separation schemes ... where necessary to promote the safe passage of ships, ${ }^{, 88}$ but this cannot be done unilaterally. The state must develop a regulatory proposal for IMO approval in cooperation with other states bordering the strait. ${ }^{89}$

Article 234 allows for greater coastal state control over ice covered areas. Coastal states can unilaterally adopt

regulations for the prevention, reduction and control of marine pollution from vessels in ice-covered areas within the limits of the exclusive economic zone, where particularly severe climatic conditions and the presence of ice covering such areas for most of the year create obstructions or exceptional hazards to navigation, and pollution of the marine environment could cause major harm to or irreversible disturbance of the ecological balance. $^{90}$

It is not clear how much ice covering is required to give effect to this article. While much of the Bering Strait Region is covered by ice half of the year, ${ }^{91}$ this may be reduced with climate change. It is also not clear from the text if the coastal state's ability to regulate ice covered areas under article 234 trumps the limitations imposed by articles regulating international

87. Van Dyke, supra note 80 , at 184 . Article 220 of UNCLOS allows a coastal State to investigate and detain foreign ships suspected of violating pollution laws in the coastal State's territorial sea or exclusive economic zone, but it is not clear what enforcement measures a coastal State could take against foreign vessels in an international strait.

88. UNCLOS, supra note 65, art. 41(1).

89. UNCLOS, supra note 65, art. 41(4-5).

90. UNCLOS, supra note 65, art. 234.

91. AMSA REPORT, supra note 2, at 106 (explaining that sea ice typically develops along the coasts in October and November and retreats northward from May to July); see also The Cyrosphere Today, The Univ. of Ill. at Urbana-Champaign Polar Research GROUP, DEP'T OF ATMOSPHERIC SCI., http://arctic.atmos.uiuc.edu/cryosphere/ (last visited Feb. 15, 2014, archived at http://perma.cc/JFE6-X8J5) (showing ice coverage of the Bering Sea in square kilometers); Sea Ice, Alaska Center for Climate Assessment \& Policy, https://web.archive.org/web/20120913071336/http://ine.uaf.edu/accap/sea_ice.html (last visited Feb. 15, 2014, archived at http://perma.cc/5TCH-LRRZ) (explaining that sea ice is present along or close to the northern coast for eight to ten months of the year and affects much of the western coastline for at least several months of most years); Community: Diomede, General Overview, Geography and Climate, State of Alaska, Department of COMMERCE, http://commerce.alaska.gov/cra/DCRAExternal/community/Details/9770db483493-41e4-b104-a4f5ea1a723a (last visited Feb. 15, 2014, archived at http://perma.cc/Y9L9-LW6M) (the Bering Strait is generally frozen between mid-December and mid-June). 
straits.

Article 211 offers another route to greater coastal state control in the context of pollution prevention, where justified by an area's oceanographical and ecological conditions, as well as the particular character of its traffic. ${ }^{92}$ A coastal state can, after consulting with other states concerned, submit a request to IMO for permission to adopt laws on pollution prevention or navigational practices. ${ }^{93}$ The proposal cannot include "design, construction, manning or equipment standards other than generally accepted international rules and standards." 94

Article 211 is the only article in UNCLOS that refers to routing systems. It allows States, acting through IMO, to designate routing systems "designed to minimize the threat of accidents which might cause pollution of the marine environment, including the coastline, and pollution damage to the related interests of coastal States." 95

\subsubsection{Convention for the Safety of Life at Sea}

The Convention for the Safety of Life at Sea (SOLAS) ${ }^{96}$ is more directly relevant to the ship communications systems discussed in this Article than UNCLOS. SOLAS, and its associated codes, set international safety standards for the construction, machinery, equipment, and operation of merchant ships. ${ }^{97}$ Flag states are responsible for ensuring compliance of

92. UNCLOS, supra note 65, art. 211(6)(a).

93. UNCLOS, supra note 65, art. 211(6)(a). The state must also submit scientific and technical evidence in support of the request. Id. If IMO finds that the request is justified, the coastal state may put the proposal into effect, provided 15 months have passed since the submission of the request. UNCLOS, supra note 65, art. 211(6)(a).

94. UNCLOS, supra note 65 , art. 211(6)(c).

95. UNCLOS, supra note 65, art. 211(1). The International Convention for the Safety of Life at Sea, discussed infra, provides far more detail on routing measures than UNCLOS.

96. International Convention for the Safety of Life at Sea, Nov. 1, 1974, 32 U.S.T. 47, 1226 U.N.T.S. 213 [hereinafter SOLAS], (as amended). SOLAS has been ratified by all Arctic countries. See Status of Multilateral Conventions and Instruments in Respect of which the International Maritime Organization or its Secretary-General Performs Depositary or Other Functions, IMO (Sept. 30, 2013), http://www.imo.org/About/Conventions/StatusOfConventions/Documents/Status\%20-

\%202013.pdf, archived at http://perma.cc/ZP7U-B96X [hereinafter Convention Status]. The amended version of Chapter V of SOLAS, which concerns navigation, came into force in 2002. See Traffic Services, IMO, http://www.imo.org/OurWork/Safety/Navigation/Pages/VesselTrafficServices.aspx (last visited Feb. 15, 2014, archived at http://perma.cc/4X3G-PZNZ).

97. International Convention for the Safety of Life at Sea (SOLAS), 1974, IMO, http://www.imo.org/About/Conventions/ListOfConventions/Pages/International-Conventionfor-the-Safety-of-Life-at-Sea-(SOLAS),-1974.aspx, archived at http://perma.cc/4UG3WHXT. SOLAS also includes standards for passenger ships, although there are not yet any international construction requirements for cruise ships in polar operations. AMSA REPORT, supra note 2, at 55. Cruise ships may operate in the Arctic at certain times of the year and in 
their ships with SOLAS. ${ }^{98}$

IMO regulations under SOLAS allow IMO to adopt ship routing systems that direct vessel traffic in certain areas, ${ }^{99}$ as well as ship reporting systems that facilitate communication between vessels and shore-based facilities. ${ }^{100}$ These can be established to improve the safety of life at sea, the safety and efficiency of navigation, or the protection of the marine environment. ${ }^{101}$ SOLAS regulations also provide for shore-based vessel traffic systems, ${ }^{102}$ which can range from a simple information exchange with ships to comprehensive management of vessel traffic in a particular area. $^{103}$ SOLAS regulations require most large ships engaged in international voyages to be equipped with Automatic Identification Systems and Long-Range Identification and Tracking Systems that automatically transmit information about the ship to other ships and coastal authorities. ${ }^{104}$ Like UNCLOS, SOLAS imposes a duty on states to provide navigational warnings. ${ }^{105}$

SOLAS also provides for an "ice patrol" of the North Atlantic near the Grand Banks of Newfoundland, where icebergs are common. ${ }^{106}$ The patrol has been in place since the aftermath of the Titanic sinking. ${ }^{107}$ It is led by the United States, and each SOLAS party interested in the services helps pay for the cost of the patrol. ${ }^{108}$ The Ice Patrol and the Canadian Ice Service issue one daily iceberg analysis to vessels ${ }^{109}$ during the period of

areas of open water. AMSA REPORT, supra note 2, at 55

98. SOLAS, supra note 96.

99. SOLAS, supra note 96, Reg. V/10.1.

100. SOLAS, supra note 96 , Reg. V/11.1.

101. IMO, Guidance Note on the Preparation of Proposals on Ships' Routeing Systems and Ship Reporting Systems for Submission to the Sub-Committee on Safety of Navigation $\S 1.2$, IMO Doc. MSC/Cir. 1060 (Jan. 6, 2003) [hereinafter SOLAS Guidelines].

102. SOLAS, supra note 96, Reg. V/12.

103. See Vessel Traffic Services, supra note 96.

104. SOLAS, supra note 96, Regs. V/19.2.1, V/19.2.4.

105. SOLAS, supra note 96, Reg. V/4 ("Each Contracting Government shall take all steps necessary to ensure that, when intelligence of any dangers is received from whatever reliable source, it shall be promptly brought to the knowledge of those concerned and communicated to other interested Governments."); see also SOLAS, supra note 96, Reg. V/5 (encouraging governments to provide meteorological services and warnings on waves, ice, wind, and other data and transmit weather observations to vessels free of charge).

106. See SOLAS, supra note 96, Reg. V/6; SOLAS, supra note 96, appendix to chapter $\mathrm{V}, \S 1.2$.

107. About International Ice Patrol, U.S. COAST GUARD, http://www.navcen.uscg.gov/?pageName=IIPHome (last visited Feb. 15, 2015, archived at http://perma.cc/66E3-TZ8P).

108. See SOLAS, supra note 96, Reg. V/6.4-6.5; SOLAS, supra note 96, appendix to chapter V, $\$ 2$. Contributions are based on the average annual gross tonnage of each states' ships passing through the iceberg region during the previous three ice seasons. SOLAS, supra note 96, appendix to chapter $\mathrm{V}, \S 2$.

109. About International Ice Patrol, supra note 107. 
patrol, which lasts from February 15 to July 1 each year. ${ }^{110}$ According to the Ice Patrol, no vessel that has heeded the Ice Patrol's published iceberg limit has collided with an iceberg. ${ }^{111}$

\subsubsection{Convention for the International Regulations for Preventing Collisions at Sea}

The Convention for the International Regulations for Preventing Collisions at Sea (COLREGs) aims to avoid collisions and ensure navigational safety. ${ }^{112}$ The term "collision" is not defined and could be interpreted to apply to vessel-whale collisions, although the convention only refers to collisions between two vessels. ${ }^{113}$

COLREGs rule 5 requires that every vessel maintain a proper lookout by sight, hearing, and other means at all times, so as to make a full appraisal of the situation and of the risk of collision. ${ }^{114}$ If interpreted to apply to vessel-whale collisions, this provision could be used to justify requirements for marine-mammal observers on vessels.

Rule 6 requires every vessel to proceed at a safe speed at all times. ${ }^{115}$ Factors in determining a safe speed include consideration of traffic and environmental conditions, such as ice and the presence of fishing vessels. ${ }^{116}$

Rule 10 requires vessels to follow IMO-adopted traffic separation schemes. ${ }^{117}$ Fishing vessels "shall not impede the passage of any vessel following a traffic lane," but are not banned from fishing. ${ }^{118}$ This could be interpreted to apply to subsistence fishing and whaling.

\subsubsection{Convention for the Prevention of Pollution from Ships}

The International Convention for the Prevention of Pollution from Ships (MARPOL) ${ }^{119}$ allows Special Areas of the ocean to be designated for

110. See SOLAS, supra note 96, Reg. V/6.2.

111. About International Ice Patrol, supra note 107.

112. Convention on the International Regulations for Preventing Collisions at Sea, Oct. 20, 1972, 1050 U.N.T.S. 16 [hereinafter COLREGs]. COLREGs has been ratified by all Arctic countries. See Convention Status, supra note 96. COLREGs is implemented through federal law. See 33 U.S.C. $§ 1602$ (2002), (International Regulations).

113. COLREGs, supra note 112.

114. COLREGs, supra note 112 , rule 5.

115. COLREGs, supra note 112 , rule 6 .

116. COLREGs, supra note 112 , rule 6 .

117. COLREGs, supra note 112 , rule 10.

118. COLREGs, supra note 112, rule 10(i); see also COLREGs, supra note 112, rule 9(c) ("A vessel engaged in fishing shall not impede the passage of any other vessel navigating within a narrow channel or fairway.") Similarly, small vessels (less than 20 meters in length) must not impede the safe passage of a power-driven vessel following a traffic lane. COLREGs, supra note 112, rule 10(j).

119. Protocol of 1978 Relating to the International Convention for the Prevention of 
protection from oil pollution, ${ }^{120}$ noxious liquid substances in bulk, ${ }^{121}$ sewage, ${ }^{122}$ and garbage. ${ }^{123}$

\subsubsection{Convention on Standards of Training, Certification and Watchkeeping for Seafarers}

The 1978 Convention on Standards of Training, Certification and Watchkeeping for Seafarers (STCW), ${ }^{124}$ and the Seafarers' Training, Certification and Watchkeeping Code originally adopted in $1995,{ }^{125}$ contain international standards for mariner license qualifications, training, and deck and engineering watchstanding. ${ }^{126}$ To obtain a certain level of certification, ${ }^{127}$ a mariner must have knowledge of navigation and maneuvering in ice-covered waters ${ }^{128}$ and in traffic separation schemes. ${ }^{129}$ While in the ports of a party to the convention, ship officers (including those from states that are non-parties) are subject to verification that all mariners on board have the proper training certificates under the

Pollution from Ships, 1973, Feb. 17, 1978, 1340 U.N.T.S. 62 [hereinafter MARPOL]. MARPOL has been ratified by all Arctic countries. Convention Status, supra note 96, at 108-12.

120. MARPOL, supra note 119, at Annex I; IMO, Guidelines for the Designation of Special Areas Under MARPOL 73/78 and Guidelines for the Identification and Designation of Particularly Sensitive Sea Areas, IMO Assemb. Res. A. 927(22) § 2.1 (Nov. 29, 2001) [hereinafter MARPOL Guidelines]; see also Special Areas Under MARPOL, IMO, www.imo.org/OurWork/Environment/PollutionPrevention/SpecialAreasUnderMARPOL/Pa ges/Default.aspx (last visited Feb. 15, 2014, archived at http://perma.cc/5GMY-SEXW) (noting the existence of a Baltic Sea special area under Annex IV).

121. MARPOL, supra note 119, at Annex II; MARPOL Guidelines, supra note 120, at Annex 1, 2.1 .

122. MARPOL, supra note 119, at Annex IV; MARPOL Guidelines, supra note 120, at Annex 1, 2.1 .

123. MARPOL, supra note 119, at Annex V; MARPOL Guidelines, supra note 120, at Annex 1, § 2.1.

124. International Convention on Standards of Training, Certification and Watchkeeping for Seafarers, July 7, 1978, 1361 U.N.T.S. 190, archived at http://perma.cc/F5SU-JS4L (as amended) [hereinafter STCW Convention]. The STCW Convention has been ratified by all Arctic countries. Convention Status, supra note 96.

125. See Seafarers' Training, Certification and Watchkeeping Code, Adopted as Resolution 2 by the 1995 Conference of Parties to the STCW Convention, July 7, 1995, 1969 U.N.T.S. 41, 67, archived at http://perma.cc/P3UN-VDRG [hereinafter STCW Code]. Federal regulations implementing the STCW Convention and Code are codified at 46 C.F.R. $\S \S 15.1101-.1111$ (1997).

126. STCW Convention supra note 124. The STCW Convention does not apply to fishing vessels or "wooden ships of primitive build." See STCW Convention, supra note 124, art. III.

127. See STCW Convention, supra note 124, at appendix to Reg. II/2 (pertaining to certification of masters and chief mates of ships of 200 gross register tons or more).

128. See STCW Convention, supra note 124, at appendix to Reg. II/2, 2(a)(iii), 7(n).

129. See STCW Convention, supra note 124, at appendix to Reg. II/2, 2(a)(v), 7(o). 
convention. $^{130}$

\subsubsection{International Convention on Maritime Search and Rescue}

The 1979 International Convention on Maritime Search and Rescue (SAR Convention) provides for the establishment of ship reporting systems for search and rescue purposes and encourages the use of existing systems as well as voluntary reporting for these purposes. ${ }^{131}$ IMO has established thirteen major search and rescue areas around the world. ${ }^{132}$

\subsubsection{Arctic Council}

The Arctic Council, established through the Ottawa Declaration of 1996, is an intergovernmental forum composed of Canada, Denmark (for Greenland), Finland, Iceland, Norway, Russia, Sweden, and the United States. ${ }^{133}$ In addition to these Member States, indigenous peoples' organizations such as the Inuit Circumpolar Council serve as Permanent Participants. ${ }^{134}$ The Arctic Council has issued numerous non-binding guidelines and reports such as the Arctic Environmental Protection Strategy, ${ }^{135}$ the Arctic Climate Impact Assessment, ${ }^{136}$ the Arctic Marine Shipping Assessment, ${ }^{137}$ and the Arctic Council Offshore Oil and Gas Guidelines. $^{138}$

Through the 2008 Ilulissat Declaration, ${ }^{139}$ five of the eight Arctic

130. STCW Convention, supra note 124, art. X(1).

131. International Convention on Maritime Search and Rescue art. 6, Apr. 27, 1979, 1405 U.N.T.S. 119 [hereinafter SAR Agreement].

132. See International Convention on Maritime Search and Rescue (SAR), IMO, http://www.imo.org/About/Conventions/ListOfConventions/Pages/International-Conventionon-Maritime-Search-and-Rescue-(SAR).aspx (last visited Dec. 7, 2013, archived at http://perma.cc/7TQA-KWZN).

133. See Governments of the Artic Countries, Declaration on the Establishment OF THE ARCTIC COUNCIL (Sept. 19, 1996), archived at http://perma.cc/3W97-3YJU.

134. Id.

135. Arctic Environmental Protection Strategy, June 14, 1991, 30 I.L.M. 1624, archived at http://perma.cc/J7UE-K68E.

136. Arctic Climate Impact Assessment, ARCTIC Monitoring AND Assessment Programme (2004), http://amap.no/acia/ (last visited Feb. 15, 2014, archived at http://perma.cc/6DBC-WX8Q).

137. AMSA REPORT, supra note 2.

138. Arctic Council, Protection of the Arctic Marine Environment Working Group, ARctic OfFShORE OIL AND GAS Guidelines (Apr. 29, 2009), archived at http://perma.cc/KW2G-PR4M.

139. The Ilulissat Declaration, Arctic Ocean Conference (May 28, 2008), archived at http://perma.cc/9FHS-JC7G. Canada, Denmark, Norway, Russia, and the United States met in Ilulissat, Greenland for the conference. Id. Representatives from the three other Arctic states (Iceland, Finland, and Sweden) were apparently not invited to participate. See id. 
states (those with coastline on the Arctic Ocean) declared that the "law of the sea" 140 is an "extensive international legal framework," and that they "therefore see no need to develop a new comprehensive international legal regime to govern the Arctic Ocean." ${ }^{\text {"141 }}$ That said, the coastal states expressed a willingness to cooperate in the areas of environmental protection, navigational safety, and scientific research, and to form bilateral and multilateral arrangements between relevant states. ${ }^{142}$

The following year, the Arctic Council published the 2009 Arctic Marine Shipping Assessment (AMSA), ${ }^{143}$ providing recommendations concerning safety, marine infrastructure, and environmental and subsistence protection. ${ }^{144}$ AMSA encourages states to work with IMO to harmonize and update standards for vessels operating in the Arctic. ${ }^{145}$ In particular, AMSA calls for engagement with Arctic communities and environmental protection, including the designation of environmentally sensitive areas. ${ }^{146}$

In 2011, the Arctic Council issued its first legally binding instrument, the Agreement on Cooperation on Aeronautical and Maritime Search and Rescue in the Arctic. ${ }^{147}$ The Agreement recognizes the increase in Arctic maritime traffic and activity. ${ }^{148}$ It requires parties to consider using ship reporting systems in promoting mutual search and rescue cooperation and exchange of experience. ${ }^{149}$

In 2013, the Arctic Council issued the Agreement on Cooperation on Marine Oil Pollution Preparedness and Response in the Arctic, ${ }^{150}$ requiring each party to "maintain a national system for responding promptly and effectively to oil pollution incidents."

\subsection{Bilateral Treaties Relevant to the Bering Strait Region}

The United States and Russia have several agreements that apply to the Bering Strait Region, including the 1972 Agreement on Cooperation in

140. This language implies a reference to UNCLOS, although the Ilulissat Declaration did not directly refer to this convention.

141. The Ilulissat DeClaration, supra note 139.

142. The Ilulissat DeClaration, supra note 139.

143. AMSA REPORT, supra note 2.

144. AMSA REPORT, supra note 2, at 6-7.

145. AMSA REPORT, supra note 2 , at 6.

146. AMSA REPORT, supra note 2, at 6-7.

147. Agreement on Cooperation on Aeronautical and Maritime Search and Rescue in the Arctic, May 12, 2011, archived at http://perma.cc/JS68-YXX7.

148. Id. at preamble.

149. Id. art. 9(3).

150. Agreement on Cooperation on Marine Oil Pollution Preparedness and Response in the Arctic, May 15, 2013, archived at http://perma.cc/F7GD-7ZVR.

151. Id. art. 4. 
the Field of Environmental Protection, ${ }^{152}$ a 1972 Agreement on Cooperation in Combating Pollution in the Bering and Chukchi Seas, ${ }^{153}$ and a 1995 memorandum of understanding on areas such as search and rescue and maritime law enforcement. ${ }^{154}$

Russia also has its own laws applicable to the Russian side of the Bering Strait Region, including national safety and environmental standards specific to navigation in Russian Arctic waters. ${ }^{155}$ Russia employs a ship inspection system for passage through the Northern Sea Route, which extends through the Bering Strait. ${ }^{156}$

The United States will need to continue cooperating with Russia if it plans to submit a regulatory proposal for the Bering Strait Region to IMO ${ }^{157}$ It could also develop a bilateral agreement just between the two countries (without IMO's involvement), although this would not bind vessels from other countries.

152. Agreement on Cooperation in Environmental Protection, U.S.-U.S.S.R, May 23, 1972, T.I.A.S. No. 7345.

153. Agreement Between the Government of the United States and the Government of the Union of Soviet Socialist Republics Concerning Cooperation in Combating Pollution in the Bering and Chukchi Seas in Emergency Situations, May 11,1989, T.I.A.S. No. 11446 (this Agreement adopted the Joint Contingency Plan against Pollution in the Bering and Chukchi Seas).

154. Admiral Robert E. Kramek \& Commander W. Russell Webster, Steaming with the Russians, U.S. NAval Institute Proceedings Magazine, Dec. 1997, archived at http://perma.cc/Y9YL-K692.

155. AMSA REPORT, supra note 2, at 67; see also Amendments to Laws Regulating Merchant Shipping on the Northern Sea Route, PRESIDENT OF RUSSIA (July 30, 2012, 3:10 PM), http://eng.kremlin.ru/acts/4232, archived at http://perma.cc/9A6F-GT8V; Northern Sea Route Law Passed by the Federation Council, ArCtiC InFo (July 19, 2012), http://www.arctic-info.com/News/Page/northern-sea-route-law-passed-by-the-federationcouncil, archived at http://perma.cc/UBF3-88RZ. This law provides for modern infrastructure to ensure safe navigation of vessels along the Northern Sea Route, including navigational support and ice-breaking. Id. The law established a federal agency that reviews applications for the right to sail in the waters and issues sailing permits. Id. Permits will require proof of insurance or ability to pay for pollution damage. Id.

156. AMSA REPORT, supra note 2, at 67.

157. See Tim Bradner, Arctic Drill Rules Advance; Shell Spill Dome OK'd, ALASKA Journal OF COMMERCE (Aug. 15, 2013), http://www.alaskajournal.com/Alaska-Journal-ofCommerce/August-Issue-3-2013/Arctic-drill-rules-advance-Shell-spill-dome-OKd/, archived at http://perma.cc/4E5Y-CP7W (U.S. Coast Guard Rear Admiral Thomas Ostebo suggested that Russia has a lot of influence over a vessel traffic system because the bulk of the Arctic traffic is over Russia's Northern Sea Route, across the Arctic from Europe to Asia, and through the Bering Strait). 


\subsection{United States Law}

\subsubsection{Ports and Waterways Safety Act}

The 1972 Ports and Waterways Safety Act and its amendments (collectively, PWSA) aim to ensure safe navigation as well as environmental protection. ${ }^{158}$ PWSA applies to the navigable waters of the United States (out to twelve nautical miles) ${ }^{159}$ and, in some cases, to the "marine environment," which includes the 200 nautical mile Exclusive Economic Zone of the United States. ${ }^{160}$

The U.S. Coast Guard is the main agency responsible for PWSA and other maritime laws in the United States and has the authority to implement vessel reporting, routing, and management measures in both internal and offshore waters. ${ }^{161}$ The Coast Guard can construct, operate, maintain, improve, or expand vessel traffic services in any port or place within the United States' territorial sea, ${ }^{162}$ or in any area covered by an international agreement. ${ }^{163}$

\subsubsection{Navigation Safety Regulations}

The Coast Guard promulgated the navigation safety regulations (NSRs) in 1977 for almost all navigable US waters. ${ }^{164}$ These regulations require most large vessels to carry designated charts and nautical publications and be equipped with radar and an automated trafficking

158. See Ports and Waterways Safety Act, Pub. L. No. 92-340, 86 Stat. 424 (1972) (codified as amended at 33 U.S.C. $\S \S 1221-1236$ (2006)) [hereinafter PWSA].

159. 33 U.S.C. $\S 1222(5)(2006)$.

160. PWSA broadly defines "marine environment" to include the navigable waters of the United States and the land and resources within and under those waters, including the seabed and subsoil of the Outer Continental Shelf, fishery resources, "and the recreational, economic, and scenic values of such waters and resources." 33 U.S.C. § 1222(1) (2006).

161. See, e.g., 33 U.S.C. $\$ 1230$ (c) (2006) (authorizing Coast Guard to implement vessel traffic services); 33 U.S.C. $\$ 1230(d)$, (2006) (authorizing Coast Guard to implement ship reporting systems); 33 C.F.R. $\$ 160.201$ (2013) (requiring ships to report advance notice of arrival); id. $\S 165$ (2013) (regulated navigation areas); id. § 167 (2013) (offshore traffic separation schemes); id. § 169 (2013) (ship reporting systems).

162. Port and Tanker Safety Act (PTSA), Pub. L. No. 95-474, §4(a), 92 Stat. 1471, (1978), reprinted in 1978 U.S.C.C.A.N. 3270; Oil Pollution Act of 1990 (OPA 1990), Pub. L. No. 101-380, tit. IV, §4107(a), 104 Stat. 484, 514 (codified as amended at 33 U.S.C. $\S 1223(\mathrm{a})(1))$.

163. See 33 U.S.C. $§ 1230$ (1998) (authorizing negotiations to establish vessel traffic systems and listing the existing ship reporting systems); National Vessel Traffic Services Regulations (VTS Final Rules), 59 Fed. Reg. 36316-36317 (July 15, 1994) (reorganizing regulations and making participation in VTSs mandatory), codified at 33 C.F.R. pts. 26, 160 , 162,164 , and 165 .

164. 33 C.F.R. $§ 164$ (2013); see also U.S. Coast Guard, Final Rules, Navigation Safety Regulations, 42 Fed. Reg. 5956 (Jan. 31, 1977). 
system. ${ }^{165}$ They include criteria for determining safe speed ${ }^{166}$ and other safety standards.

\subsubsection{U.S. Coast Guard Authorization Act}

Section 307 of the 2010 U.S. Coast Guard Authorization Act aims to implement the Arctic Council's 2009 Arctic Marine Shipping Assessment. ${ }^{167}$ It encourages the Coast Guard (through the Secretary of the Department of Homeland Security) to negotiate with other Arctic nations and execute agreements under IMO regarding marine safety, including the placement and maintenance of aids to navigation, oil spill prevention and response capability, tracking systems, and search and rescue. ${ }^{168}$ The Act requires the Coast Guard to "promote safe maritime navigation by means of icebreaking where necessary, feasible, and effective." 169

\subsubsection{National Security Policy}

The National Plan to Achieve Maritime Domain Awareness (MDA Plan), ${ }^{170}$ one of eight plans formulated pursuant to the National Strategy for Maritime Security, ${ }^{171}$ encourages the use and expansion of tracking systems and other tools to obtain comprehensive information about vessels located outside of the twelve-nautical mile territorial sea. ${ }^{172}$

A 2009 National Security Presidential Directive sets out the United States' Arctic policy. ${ }^{173}$ It recognizes the need to work with the Arctic Council, IMO, and others on international agreements for environmental protection and to improve the safety and security of maritime

165. See 33 C.F.R. $\S \S 164.30-.38, .41, .43, .46, .72$ (2013).

166. 33 C.F.R. $\$ 164.11$ (p) (2013) (listing eight factors to be considered in determining safe speed).

167. U.S. Coast Guard Authorization Act, PuB. L. No. 111-281, § 307, 124 Stat. 2905 (2010) (entitled Arctic Marine Shipping Assessment Implementation). A new Coast Guard Authorization Act is issued each year to authorize appropriations to the Coast Guard.

168. Id. $\S 307(\mathrm{~b})(1)$.

169. Id. § 307(e).

170. Dep't of Homeland Sec., National Plan to Achieve Maritime Domain AWARENESS $i$ (Oct. 2005), archived at http://perma.cc/J972-2ZSP.

171. Id.

172. The eight supporting plans are: 1) National Plan to Achieve Domain Awareness; 2) Global Maritime Intelligence Integration Plan; 3) Maritime Operational Threat Response Plan; 4) International Outreach and Coordination Strategy; 5) Maritime Infrastructure Recovery Plan; 6) Maritime Transportation System Security Plan; 7) Maritime Commerce Security Plan; and 8) Domestic Outreach Plan. Id.

173. George W. Bush, National Security Presidential Directive (NSPD) 66/Homeland Security Presidential Directive (HSPD) 25: Arctic Region Policy (2009), archived at $\mathrm{http}: / /$ perma.cc/ZBW4-V2U2. 
transportation. ${ }^{174}$ The Directive specifically refers to the need to consider ship routing and reporting systems, traffic separation and vessel traffic management schemes in Arctic chokepoints, underwater noise standards for commercial shipping, and pollution prevention and response standards. ${ }^{175}$ It urges Congress to ratify UNCLOS. ${ }^{176}$

\subsubsection{White House and Coast Guard Strategies for the Arctic Region}

In 2013, both the White House and the Coast Guard released strategies for the Arctic region. The White House's strategy focuses on advancing US security interests, promoting responsible Arctic stewardship, and strengthening international cooperation. ${ }^{177}$ One of the objectives of the strategy is to cooperate with other Arctic nations to advance common objectives in the Arctic region, including "the promotion of safe, secure, and reliable Arctic shipping, a goal that is best pursued through the International Maritime Organization in coordination with other Arctic states, major shipping states, the shipping industry and other relevant interests." 178

The Coast Guard's strategy prioritizes improving awareness of maritime threats and hazards; modernizing governance by working with stakeholders and the International Maritime Organization; and broadening domestic and international partnerships to increase coordination, enhance efficiency, and reduce risk. ${ }^{179}$

Both the White House and the Coast Guard's Strategy call for accession to the Law of the Sea Convention. ${ }^{180}$

\subsubsection{Endangered Species Act and the Marine Mammal Protection Act}

The Endangered Species Act (ESA) is relevant to the protection of endangered and threatened species in the Bering Sea Region. ESA section 9 prohibits the Coast Guard or any other person from "taking" (harassing, harming, wounding, killing, etc.) any endangered species of fish or wildlife within the United States or its territorial sea. ${ }^{181}$

174. Id. at $\operatorname{III}(\mathrm{C})(1-2), \operatorname{III}(\mathrm{F})(3)$.

175. Id. at III $\mathrm{F}(2-4)$.

176. Id. at III C(4).

177. The White House, National Strategy for the Arctic Region (2013), archived at http://perma.cc/V29A-ZD88 [hereinafter White House ARCTiC STRATEGY].

178. Id. at 10. As of this writing, the White House is working on an implementation plan for the Strategy.

179. USCG ARCTIC StRATEGY, supra note 4, at 22.

180. White House Artic Strategy, supra note 177, at 2; USCG Arctic Strategy, supra note 4 , at 22 .

181. See 16 U.S.C. $\S \S 1538(a)(1)(B), 1532(19)$, 1532(13) (1973) (prohibiting take, 
The Marine Mammal Protection Act (MMPA) similarly protects marine mammals. ${ }^{182}$ The National Marine Fisheries Service (NMFS) of the National Oceanic and Atmospheric Administration (NOAA) regulations implementing MMPA prohibit "the negligent or intentional operation of an aircraft or vessel, or the doing of any other negligent or intentional act which results in disturbing or molesting a marine mammal."183

NMFS has developed specific regulations to regulate close vessel approaches to large whales in Alaska and other areas. In 2001, NMFS issued a rule establishing a one-hundred-yard-approach limit for endangered humpback whales within 200 nautical miles of Alaska. ${ }^{184}$ The rule also required vessels to travel at a "slow, safe speed" when near humpback whales. ${ }^{185}$ The rule was mainly aimed at whale watchers, although NMFS specifically did not exempt commercial fishing vessels in transit. ${ }^{186}$

\subsection{Alaska Law}

Vessels could be subject to the laws of the State of Alaska if within three miles of state shorelines, ${ }^{187}$ which include Little Diomede Island, St. Lawrence Island, Nunivak Island, and St. Matthew Island within the Bering

defining take, and including federal departments, instrumentalities, and agents in its definition of "person" for ESA purposes).

182. See 16 U.S.C. $§ 1372$ (a) (1972) (prohibiting the unauthorized "take" of all marine mammals).

183. 50 C.F.R. $\S \S 216.11,216.3$ (1978) (prohibiting take and defining take). Under ESA and MMPA, special permission for non-intentional take can be issued through an Incidental Take Permit or an Incidental Harassment Authorization. See ESA, 16 U.S.C. § 1539(a)(1)(B) (1973) (allowing the Fish and Wildlife Service or NMFS to issue permits to non-federal entities for "incidental take" of federally listed fish and wildlife species pursuant to a Habitat Conservation Plan submitted by the entity and approved by the agency); MMPA, 16 U.S.C. $\S 1371(a)(5)(D)$ (1972) (directing NMFS to authorize, upon request, the incidental, but not intentional, taking of small numbers of marine mammals of a species or population stock, by United States citizens who engage in a specified activity (other than commercial fishing) within a specified geographical region if certain findings are made and a notice of a proposed authorization is provided to the public for review).

184. Regulations Governing the Approach to Humpback Whales in Alaska, 66 Fed. Reg. 29502 (May 31, 2001) (to be codified at 50 C.F.R. pt. 224).

185. Id. at 29503. The rule refers to the definition of "safe speed" in the Inland Navigational Rules (33 U.S.C. § 2006 (2003)) and the International Regulations for Preventing Collisions at Sea 1972 (COLREGs) (33 U.S.C. § 1602 (2006)).

186. Id. at 29504.

187. Under the Coastal Zone Management Act (16 U.S.C. $\$ 1453$ (1972)), a state has title and ownership of waters out to three nautical miles. See 43 U.S.C. $\$ 1312$ (1953) (providing for a three-nautical-mile seaward boundary of states). U.S.-flagged vessels would clearly be subject to Alaska law, to the extent it is not inconsistent with United States law and the Constitution. Foreign-flagged vessels could challenge a law if there is a perceived conflict between Alaska law and international law, particularly if there is a conflict with a U.S.ratified convention. 


\section{Strait Region. ${ }^{188}$}

The State of Alaska requires state-licensed pilotage in Alaskan waters for certain types of vessels, including some foreign-flagged vessels. ${ }^{189}$ The State Marine Pilot Coordinator is able to monitor vessel traffic through the Automatic Information System, ${ }^{190}$ although this does not provide information on whether vessels are complying with pilotage requirements. For the most part, compliance is voluntary. ${ }^{191}$

Alaska law requires vessels over 200 gross tons to carry a licensed VHF radiotelephone installation equipped with at least five channels. ${ }^{192}$ Tank vessels transporting oil or petroleum products and self-propelled nontank vessels that are over 400 gross tons are required to have a vessel oil

188. Alaska Admin. Code title 12, §56.100(16) (1971). There are federal pilotage requirement in waters beyond the three-mile mark, which are enforced by the Coast Guard.

189. See Alaska Stat. $§ 08.62 .160$ (2012) ("A vessel subject to this chapter navigating the inland or coastal water of or adjacent to the state as determined by the board in regulation shall employ a pilot holding a valid license under this chapter."). Pursuant to AlasKa Stat. $\S 08.62 .180$ (2012), the following vessels are exempt from the pilotage requirement:

(1) vessels subject to federal pilot requirements under 46 U.S.C. 8502 [covering coastwise, seagoing vessels not leaving or entering ports] except as provided in AS 08.62.185 [covering oil tankers of 50,000 dead weight tons or greater];

(2) fishing vessels ... registered in the United States or in British Columbia, Canada;

(3) vessels propelled by machinery and not more than 65 feet in length over deck, except tugboats and towboats propelled by steam;

(4) vessels of United States registry of less than 300 gross tons and towboats of United States registry and vessels owned by the State of Alaska, engaged exclusively ... on the rivers of Alaska; ... or in the coastwise trade on the west or north coast of the United States . . . and . . Canada;

(5) vessels of Canada . . . engaged in frequent trade between . . Canada . . . and ... Alaska;

(6) pleasure craft of United States registry; [and]

(7) pleasure craft of foreign registry of 65 feet or less in overall length . . . .

Federal pilotage regulations administered by the U.S. Coast Guard cover vessels not subject to state pilotage laws (including coastwise (transiting) self-propelled vessels and tank barges). 46 U.S.C. $§ 8502$ (1983). Except for vessels in Prince William Sound, which must use pilots licensed by both the Coast Guard and Alaska, vessels subject to federal pilotage requirements are not subject to state pilotage requirements. $I d$. $\S \S 8502(\mathrm{~g})-(\mathrm{h})$. The dual state-federal jurisdiction in Prince William Sound was created by the Oil Pollution Act of 1990, Pub. L. No. 101-380, § 4116 (1990) after the Exxon Valdez spill in an effort to "promote the level of competence necessary in the uniquely vulnerable Prince William Sound." H.R. ReP. No. 101-653, pt. 143, at 101 (1990) (Conf. Rep.). A similar argument could be made for dual accountability in the Bering Strait.

190. Interview with James McDermott, State of Alaska Marine Pilot Coordinator (Nov. 9, 2012). See infra discussion on AIS in Section 2.5.2.

191. Id.

192. Alaska Stat. $§ 30.07 .010$ (2013). 
discharge prevention and contingency plan. ${ }^{193}$

One source of potential legislation is the Alaska Arctic Policy Commission created in 2012. ${ }^{194}$ The Commission was created based on a recommendation from the Alaska State Legislature's Northern Waters Task Force (NWTF), which was established in 2010 to study the effects of Arctic climate change on shipping, energy, and local industry. ${ }^{195}$ NWTF's January 2012 report to the Legislature indicated support for the development of the Polar Code, the study of a potential vessel routing scheme for circumpolar marine traffic, and the extension of the Automatic Identification System (AIS) vessel tracking across the northern part of Alaska. ${ }^{196}$

\section{SHIP COMMUNICATIONS Systems THAT COULD BE USED IN THE BERING STRAIT REGION}

This section discusses systems and regimes that could be used to regulate ships in the Bering Strait Region, including a ship routing system, a ship reporting system, vessel traffic services, tracking systems, and other tools. A chart comparing these systems is included in Appendix 1. Currently there is no mandatory or voluntary IMO-approved ship routing system, ship reporting system, or vessel traffic service for the Bering Strait region or the Arctic marine area.

\subsection{Ship Reporting System}

In a ship reporting system, vessels report certain information to the coastal state maintaining the system, and the coastal state provides navigation information to the vessels. ${ }^{197}$ SOLAS does not specify the type of information that must be reported, although reported information should be limited to information needed to serve the purposes of the system. ${ }^{198}$

193. Does My Vessel or Railroad Need an Oil Discharge Prevention Contingency Plan?, Alaska Dep't of Envtl. Conservation Division of Spill Prevention and Response, http://dec.alaska.gov/spar/ipp/marine-vessels/need-contingency-plan.htm (last visited Dec. 15, 2013, archived at http://perma.cc/SBQ8-KGMB); AlASKA ADMIN. CodE title 18, $\S$ $75.005,75.007,75.400$ (2013) (Responsibility, General oil pollution prevention requirements, Applicability).

194. H.R. Con. Res. 23, 27th Leg. (AK. 2012); see also Carey Restino, Wanted: Arctic Policy Makers, THE ARCTIC SOUnder (May 11, 2012, 1:19 PM), www.thearcticsounder.com/article/1219wanted_arctic_policy_makers, archived at http://perma.cc/WNC4-UJDS.

195. See Sponsor Statement: House Concurrent Resolution 23, Alaska Arctic Policy Commission, THE House MAJORITY (Mar. 27, 2012), http://housemajority.org/spon.php?id=27hcr23, archived at http://perma.cc/Q4QA-ABHK.

196. NWTF REPORT, supra note 4, at 24-26.

197. See Vessel Traffic Systems, supra note 96.

198. SOLAS Guidelines, supra note 101, § 6.2.2. 
This information generally includes the vessel name, radio call signs, position, speed, and course. ${ }^{199}$ Some systems call for reports on any hazardous cargoes on board, ${ }^{200}$ and the North Atlantic system requests reports on whale sightings. ${ }^{201}$

Ship reporting systems may be mandatory for use by all ships, certain categories of ships, or ships carrying certain cargoes. ${ }^{202}$ IMO may also recognize a voluntary ship reporting system in international waters if the proposed system adheres as closely as possible to IMO regulations, guidance, and criteria. ${ }^{203} \mathrm{~A}$ proposal for a ship reporting system may be submitted to IMO by any state that is party to SOLAS. ${ }^{204}$ When two or more governments have a common interest in a particular area, they should formulate a joint proposal for the ship reporting system with integrated measures and procedures for co-operation between the jurisdictions of the proposing Governments. ${ }^{205}$ If IMO adopts a system, its requirements become binding upon all commercial flag vessels of member states. ${ }^{206}$ The proposing governments (rather than IMO) are responsible for implementing ships reporting systems. ${ }^{207}$

There are at least twenty-one IMO-approved, mandatory ship reporting systems, ${ }^{208}$ including systems with environmental protection as an

199. SOLAS Guidelines, supra note 101, § 6.2.2.

200. E.g., International Maritime Organization, In the Straight of Gibraltar Traffic Separation Scheme Srea, in SHIPS' RouTEING (2010) [hereinafter Gibraltar Reporting System].

201. E.g., International Maritime Organization, Reporting Systems for Protection of Endangered North Atlantic Right Whales in Sea Areas of the North-Eastern and SouthEastern Coasts of the United States, in SHIPS' RouteING (2010) [hereinafter Atlantic Whale Reporting System].

202. SOLAS Guidelines, supra note $101, \S 2.1$.

203. SOLAS, supra note 96, Reg. V/11.4; SOLAS Guidelines, supra note 101, § 5.2.

204. SOLAS Guidelines, supra note 101, § 6.1. The proposal should indicate the objectives and need for the proposed system; categories of ships required to participate in the system; information on environmental conditions; the area; the form, manner, and communication technology required for reports; measures and systems already in place; emergency measures; and compliance measures. SOLAS Guidelines, supra note 101, 7.

205. SOLAS, supra note 96, Reg. V/11.5; SOLAS Guidelines, supra note 101, $§ 3.3$.

206. SOLAS, supra note 96, Reg. V/11.7. The system can go into effect no earlier than six months after IMO adoption. SOLAS Guidelines, supra note 101, § 7.14.

207. SOLAS, supra note 96, Reg. V/11.6; SOLAS Guidelines, supra note 101, § 6.1.

208. As of 2010, IMO-approved ship reporting systems include (1) In the Gulf of Finland, (2) On the approaches to the Polish ports in the Gulf of Gdansk, (3) In the Storebælt (Great Belt) Traffic Area, (4) West European Tanker Reporting System, (5) Off Ushant, (6) Off Les Casquets and the adjacent coastal area, (7) The Dover Strait/Pas de Calais, (8) Off the south-west coast of Iceland, (9) Off Finisterre, (10) Off the Coast of Portugal, (11) In the Strait of Gibraltar Traffic Separation Scheme Area, (12) In the Strait of Bonifacio, (13) In the Adriatic Sea, (14) In the Straits of Malacca and Singapore, (15) In the Torres Strait region and the Inner Route of the Great Barrier Reef, (16) Ship Reporting System for the Papahānaumokuākea Marine National Monument PSSA, (17) In the Galapagos PSSA, (18) 
objective $^{209}$ and systems in international straits. ${ }^{210}$ None are in the vicinity of the Bering Strait, although two are near the Arctic, ${ }^{211}$ and two are in US waters. $^{212}$

Since 1958, the U.S. Coast Guard has maintained a worldwide voluntary ship reporting system known as AMVER (Automated Mutual Assistance Vessel Rescue System). ${ }^{213}$ It is mainly used to assist with search and rescue. Participating vessels ${ }^{214}$ send a sail plan to the AMVER computer center and report their locations every forty-eight hours until arriving at their port of call. ${ }^{215}$

\subsection{Ship Routing System}

A ship routing system requires vessels meeting certain criteria (i.e., vessel size or type of cargo carried) to use specific traffic routes or avoid certain areas. ${ }^{216}$ Ship routing systems are more restrictive than reporting systems, since they allow a coastal state to actually control vessel routes.

Systems in Greenland Waters, (19) Off the North-eastern and South-eastern Coasts of the United States, (20) Off Chengshan Jiao Promontory, and (21) The Canary Islands. International Maritime Organization, Ships' Routeing, pt. G (2010).

209. E.g., In the Storebælt (Great Belt) Traffic Area (BELTREP). INTERNATIONAL Maritime Organization, Ships' Routeing, pt. G, 99 (2010) [hereinafter Great Belt Reporting System] ("The objective of the VTS Authority is to facilitate the exchange of information between the shipping and the shore in order to ensure safe passages of the bridges, support safety of navigation and protection of the marine environment."); Gibraltar Reporting System, supra note 200, 99 ("The primary objective of the system is to facilitate the exchange of information between the ship and the shore and to support safe navigation and the protection of the marine environment."); In the Torres Strait region and the Inner Route of the Great Barrier Reef (REEFREP) InTERnational Maritime Organization, Ships' Routeing, pt. G, 99 (2010) [hereinafter Torres Strait Reporting System] ("The primary objective of the system is to facilitate the exchange of information between the ship and the shore and so support safe navigation and the protection of the marine environment."); Ship Reporting System for the Papahānaumokuākea Marine National Monument PSSA, $₫ 6.2$ (establishing a ship reporting system in the Papahānaumokuākea Marine National Monument Particularly Sensitive Sea Area (PSSA) "[i]n recognition of the fragile environment in this area and potential hazards to navigation") (alteration added).

210. E.g., Gibraltar Reporting System, supra note 200; In the Straits of Malacca and Singapore, supra note 208; Torres Strait Reporting System, supra note 209.

211. These systems are (1) Off the south-west coast of Iceland; and (2) Systems in Greenland waters. See International Maritime Organization, Ships' Routeing, pt. G (2010).

212. These systems are (1) Ship Reporting System for the Papahānaumokuākea Marine National Monument PSSA; and (2) Atlantic Whale Reporting System. See id.

213. Automated Mutual Assistance Vessel Rescue System Fact Sheet, U.S. COAST GuARD, http://www.amver.com/facts/FactSheet.pdf (last visited Feb. 15, 2014, archived at http://perma.cc/8Y5D-B34X).

214. Id. Any commercial vessel, regardless of nation or flag, over 1,000 gross tons on voyages of 24 hours or greater is encouraged to enroll and participate in AMVER. Id.

215. Id.

216. SOLAS Guidelines, supra note 101, § 1.2. 
Ship routing systems can be established "to improve safety of life at sea, safety and efficiency of navigation, and/or increase the protection of the marine environment." ${ }^{217}$ IMO ship routing systems may be either voluntary or mandatory for vessels ${ }^{218}$ and may apply to "all ships, certain categories of ships or ships carrying certain cargoes. $" 219$

Routing measures may include traffic separation schemes, two-way routes, recommended tracks, deep water routes (for the benefit primarily of ships whose ability to maneuver is constrained by their draught), precautionary areas (where ships must navigate with particular caution), areas to be avoided, and other areas subject to specific regulations. ${ }^{220}$

A traffic separation scheme is "a routing measure aimed at the separation of opposing streams of traffic by appropriate means and by the establishment of traffic lanes." 221 While the original purpose of traffic separation schemes was to prevent collisions and improve the safety of international shipping, they can also be used for the protection of the marine environment ${ }^{222}$ and to avoid collisions with whales ${ }^{223}$ and other marine mammals.

An area to be avoided is "an area within defined limits in which either navigation is particularly hazardous or it is exceptionally important to avoid casualties and which should be avoided by all ships, or by certain classes of ships." ${ }^{\text {"24 }}$ These areas may be adopted for reasons of exceptional danger or especially sensitive ecological and environmental factors, ${ }^{225}$ but generally cannot be adopted if they "would impede the passage of ships through an international strait." 226

217. SOLAS Guidelines, supra note 101, §1.2; cf. SOLAS, supra note 96, Ch. V, Reg. 10.1 .

218. SOLAS Guidelines, supra note $101, \S 2.1$.

219. SOLAS, supra note 96, Reg. V/10.1; SOLAS Guidelines, supra note 101, § 2.1.

220. Ships' Routeing, InTERNATIONAL MARItIME ORGANizATION, http://www.imo.org/ourwork/safety/navigation/pages/shipsrouteing.aspx (last visited Dec. 30, 2013, archived at http://perma.cc/76WK-S2G2) ("Routeing" is the British English spelling).

221. Id.; see also 33 C.F.R. $§ 167.5(b)$ (2001) (defining traffic separation scheme as "a designated routing measure which is aimed at the separation of opposing streams of traffic by appropriate means and by the establishment of traffic lanes.").

222. SOLAS Guidelines, supra note $101, \S 1.2$ (providing that ships' routing systems may be used to "increase the protection of the marine environment")

223. E.g., Atlantic Whale Reporting System, supra note 201.

224. Ships' Routeing, supra note 220; See also 33 C.F.R. § 167.5(a) (2001) (defining area to be avoided as "a routing measure comprising an area within defined limits in which either navigation is particularly hazardous or it is exceptionally important to avoid casualties and which should be avoided by all ships or certain classes of ships.”).

225. Ships' Routeing, supra note 220.

226. U.N. Secretary-General, Law of the Sea: Rep. of the Secretary-General, 994, U.N. Doc. No. A/50/713 (Nov. 1, 1995), reprinted in NETHERLANDS INSTITUTE FOR THE LAW OF the Sea, International Organizations and the Law of the Sea Documentary 
A precautionary area is "an area within defined limits where ships must navigate with particular caution and within which the direction of flow of traffic may be recommended." 227 A precautionary area can serve to control traffic flow around an area that may pose hazards to shipping or may complement a designated area to be avoided. ${ }^{228}$

Under United States law, a Regulated Navigation Area (RNA) is a "water area within a defined boundary for which regulations for vessels navigating within the area have been established." 229 RNAs may be established to provide for navigation safety when conditions require higher standards of control than those provided by the Navigation Safety Rules. ${ }^{230}$ Such RNAs may require vessels to comply with specific criteria in order to enter the area. ${ }^{231}$ RNAs may also be established to protect an environmentally sensitive area by limiting activities such as oil transfers that would create a high risk of harm. ${ }^{232}$ RNAs may be expansive - one includes all of the navigable waters within the First Coast Guard District (the New England states). ${ }^{233}$

As indicated above in the section on UNCLOS, traffic separation schemes and other safety measures can be established for international

YEARBOOK (1998). "IMO will not adopt a proposed routeing system until it is satisfied that it does not impose unnecessary constraints on shipping." Id.; $c f$. LAW OF THE SEA, Environmental Law and Settlement of Disputes: Liber Amicorum Judge Thomas A. MENSAH 806 (Tafsir Malick Ndiaye \& Rüdiger Wolfrum eds., 2007) (referring to IMO's reluctance to adopt two mandatory Areas to be Avoided proposed by Sweden for a Particularly Sensitive Sea Area within Sweden's Exclusive Economic Zone; IMO's Subcommittee on Safety of Navigation found that the proposal did not sufficiently justify the establishment of mandatory areas and only approved voluntary areas). Thus, the state proposing the area to be avoided must be able to demonstrate the necessity for the area; otherwise, IMO may find that the area "impedes" navigation.

227. Ships' Routeing, supra note 220; see also 33 C.F.R. $\$ 167.5(\mathrm{e})$ (2001) (defining precautionary area as "a routing measure comprising an area within defined limits where ships must navigate with particular caution and within which the direction of traffic flow may be recommended").

228. See International Maritime Organization, General Provisions on Ships' Routeing, Assembly Res. A.572(14) $§ 4.5 .3$ (Nov. 20, 1985), archived at http://perma.cc/6JDB-U57B (containing diagrams illustrating the various uses of a Precautionary Area designation).

229. See 33 C.F.R. $\S 165.10$ (2013). RNAs are promulgated through a federal rulemaking process pursuant to the Ports and Waterways Safety Act. See 33 C.F.R. $\S 165.9$ (b) (2010); U.S. CoAst Guard Commandant, InStruction M16000.11: Marine SAfety MANUAL 1-44 (Oct. 11, 1996), archived at http://perma.cc/N848-BEVW, cancelled Oct. 10, 1997 [hereinafter MARINE SAFETY MANUAL]. Any person may request that a regulated navigation area be established by submitting a request to the Captain of the Port or District Commander with jurisdiction over the location. 33 C.F.R. $\S 165.5$ (2010) (Establishment procedures). The request should indicate the proposed location; the effective date of the area; proposed activities and restrictions in the area; and the necessity for the area. Id. Safety zones and security zones are established in the same manner. Id.

230. MARINE SAFETY MANUAL, supra note 229, at 1-44.

231. MARINE SAFety MANUAL, supra note 229, at 1-44.

232. MARINE SAFETY MANUAL, supra note 229, at 1-44.

233. See 33 C.F.R. $§ 165.100$ (2010). 
straits under articles 41 and 42(1)(a), but article 41(4) indicates that IMO must approve a traffic separation scheme before it can be put into force. Proposals for traffic separation schemes and other ship routing measures are submitted to $\mathrm{IMO}^{234}$ in a similar manner as those for reporting systems, ${ }^{235}$ whereby states with a common interest in a particular area submit joint proposals. ${ }^{236}$ A proposal should demonstrate the need for the particular type of system and its expected impact on navigation. ${ }^{237}$ Proposed routes should follow existing patterns of traffic flow as closely as possible. ${ }^{238}$ Proposals intended to protect the marine environment should explain how the system would reduce the risk of damage and describe any environmentally sensitive areas. $^{239}$

IMO-adopted routing systems are published in IMO's publication "Ships' Routeing." adherence to IMO-adopted systems, ${ }^{241}$ and a state that is "concerned" may monitor traffic in these systems. ${ }^{242}$

The Ports and Waterways Safety Act allows the Coast Guard to establish and maintain measures for controlling or supervising vessel traffic as well as for protecting navigation and the marine environment. ${ }^{243}$ These measures, which may be implemented in US territorial waters or in areas covered by an international agreement, include ship reporting systems, ship routing systems, vessel traffic services, tracking systems, and speed limits. ${ }^{244}$ In implementing and carrying out these measures, the Coast Guard

234. SOLAS Reg. V/10.2 recognizes IMO as the only international body for adopting ship routing systems as well as the guidelines, criteria and regulations associated with these systems. SOLAS, supra note 96, Reg. V/10.2. But SOLAS Reg. V/10.4 acknowledges that states may implement ship routing systems that have not been adopted by IMO, and encourages states to take into account IMO's guidelines, criteria and regulations on ship routing systems. SOLAS, supra note 96, Reg. V/10.4.

235. See SOLAS Guidelines, supra note 101, $\S 2-4$.

236. SOLAS, supra note 96 , Reg. V/10.5 (encouraging states to formulate joint proposals, and stating that IMO will disseminate details of the proposal to affected states); SOLAS Guidelines, supra note 101, §3.3.

237. See SOLAS Guidelines, supra note 101, §3.1. SOLAS Section 3 of the SOLAS Guidelines describes each element of a proposal. The Guidelines also refer to Part A of the IMO publication, General Provisions on Ships' Routeing (GPSR) (authorized by IMO Assembly Res. A.572(14)). These provisions explain the details of establishing each type of system (i.e., a traffic separation scheme), design criteria, use of the system, and representation of systems on charts. See SOLAS Guidelines, supra note 101, § 2.2.

238. SOLAS Guidelines, supra note 101, §3.4.1.

239. SOLAS Guidelines, supra note 101, § 3.5.2.

240. Ships' Routeing, supra note 220.

241. Rule 10 of COLREGs prescribes the conduct of vessels when navigating through traffic separation schemes adopted by IMO. COLREGs, supra note 112.

242. SOLAS, supra note 96 , Reg. V/10.6.

243. 33 U.S.C. $\S 1223$ (a) (2012).

244. Id. 
must consider a number of factors, including environmental protection. ${ }^{245}$

An exception to the Coast Guard's authority to govern ship traffic applies to foreign vessels that are not entering or leaving US ports and are in (1) innocent passage through the territorial sea of the United States, or (2) transit through US navigable waters that form a part of an international strait. ${ }^{246}$ But there is an exception to the exception: the Coast Guard can regulate these ships pursuant to an international treaty, convention, or agreement. $^{247}$ This probably means that if a vessel is simply traveling through the Bering Strait and not coming from or leaving a US port, the Coast Guard cannot regulate it unless there is an IMO-approved system in place.

\subsection{Vessel Traffic Service}

IMO defines a Vessel Traffic Service (VTS) as "a service implemented by a Competent Authority, designed to improve the safety and efficiency of vessel traffic and to protect the environment." 248 VTSs are somewhere between ship routing systems and ship reporting systems in terms of the control they give coastal states. Vessels are generally required to report the same information given in a ship reporting system, while the coastal state generally provides an information service ${ }^{249}$ and may provide navigational assistance and/or traffic organization. ${ }^{250}$ A VTS "should have

245. 33 U.S.C. $\S 1224$ (2012). Factors include (1) the scope and degree of the risk or hazard involved; (2) vessel traffic characteristics; (3) port and waterway configurations; (4) the need for exemptions from equipment requirements for certain classes of small vessels; (5) the proximity of fishing grounds, oil and gas drilling and production operations, or any other potential or actual conflicting activity; (6) environmental factors; (7) economic impact and effects; (8) existing vessel traffic services; and (9) local practices and customs, including voluntary arrangements and agreements within the maritime community. Id. The Coast Guard is required to consult with and consider the views of representatives of the maritime community, ports and harbor authorities or associations, environmental groups, and other parties who may be affected by the proposed actions. Id.

246. 33 U.S.C. $§ 1223$ (d) (2012).

247. Id.

248. IMO Guideline for Vessel Traffic Services, Resolution A.857(20) (adopted Nov. 27, 1997), annex 1, § 1.1.1 [hereinafter IMO VTS Guidelines].

249. See IALA-AISM, EXPeCtATIONS OF A VTS (Jan. 12, 2009) (stating that all VTS Centers provide information to vessels about conditions and events important to shipping and safety at sea, which may include information on the position, identity or intentions of other participating vessels in the VTS area; visibility or weather; the availability of berths or anchorages; or the status of aids to navigation, or any other information that could impact a vessel's safe transit).

250. IMO VTS Guidelines, supra note $248, \S 1.1 .9$ (explaining that a VTS generally provides an information service and may also provide navigational assistance and/or traffic organization); see also U.S. COAST GUARD COMMANDANT, INSTRUCTION M16630.3: VeSSEL Traffic Services National Standard Operating Procedures $\S \S 2 . B .2-B .3$ (Aug. 18, 2009), archived at http://perma.cc/6ERT-HR4G [hereinafter COAST GUARD SOP] (providing 
the capability to interact with the traffic and to respond to traffic situations developing in the VTS area." ${ }^{251}$ VTSs are typically interlinked with other aspects of marine traffic management, such as traffic separation schemes and ship reporting systems. ${ }^{252}$

VTSs that provide navigational assistance or traffic organization services are typically associated with ports or harbors - their main concern is to oversee vessel traffic to and from the port or harbor. ${ }^{253}$

A VTS that only provides an information service is generally known as a coastal VTS $^{254}$ and is fairly similar to a ship reporting system. ${ }^{255}$ Coastal VTSs and ship reporting systems both contribute to safety, navigation, and/or the protection of the marine environment. ${ }^{256}$ Both have the right to interact with vessel traffic, providing information when necessary. ${ }^{257}$ One difference is where they are allowed: SOLAS limits mandatory VTSs to the territorial seas of a coastal state, ${ }^{258}$ and VTSs cannot alter the legal regimes governing international straits. ${ }^{259}$ Mandatory ship reporting systems, on the other hand, can be approved by IMO for international waters and straits, ${ }^{260}$ such as the Bering Strait.

Another difference concerns IMO approval, which is required for mandatory ship reporting systems. Governments planning and implementing VTSs should endeavor to follow relevant IMO guidelines but are not required to seek IMO approval for VTSs in their territorial waters, as long as the level of traffic or risk justifies the service and the service does not impair the rights to navigation in straits. ${ }^{261}$ Approval would likely be needed for a system in an international strait that incorporates aspects of a VTS, such as the reporting system applicable to the Torres Strait. ${ }^{262}$

A VTS is particularly appropriate where there is high traffic density; traffic carrying hazardous cargoes; difficult hydrographical, hydrological, and meteorological elements; environmental considerations; or changes in

\footnotetext{
a similar explanation). Under the Coast Guard SOP, information, advice, and warnings fall within the navigation assistance service category. Id. $\S \S 2 . B .2,3 . B .4$. The Coast Guard SOP also indicates that the level of service may vary from one CGVTS to another. $I d$. $\S 2$. B.

251. IMO VTS Guidelines, supra note 248, § 1.1.1.

252. See Section 3.1, supra, providing examples of ship reporting systems and traffic separation schemes with VTSs.

253. IMO VTS Guidelines, supra note $248, \S 2.1 .2$.

254. IMO VTS Guidelines, supra note 248, § 2.1.2.

255. Captain Terry Hughes, When is a VTS not a VTS?, InTERnATIONAL Maritime CONSUlTANCY 3, http://www.maritime-vts.co.uk/VTSorNot.pdf (last visited Oct. 30, 2013, archived at http://perma.cc/X5HF-XJ8B).

256. Id.

257. Id.

258. SOLAS, supra note 96, Reg. V/12.3.

259. SOLAS, supra note 96 , Reg. V/12.5.

260. E.g., Torres Strait Reporting System, supra note 209.

261. SOLAS, supra note 96, Regs. V/12.2, 12.3, 12.5.

262. See discussion of Torres Strait Reporting System infra Section 4.1.
} 
the traffic pattern resulting from developments in the area. ${ }^{263}$

As in the case of ship reporting and routing systems, IMO guidelines call for cooperation and agreement when two or more nations have a common interest in establishing a vessel traffic service for a given area. ${ }^{264}$ A VTS established by multiple countries "should have uniform procedures and operations." 265 Once a VTS is established, parties to SOLAS "shall endeavour [sic] to secure the participation in, and compliance with, the provisions of vessel traffic services by ships entitled to fly their flag." 266

U.S. Coast Guard Vessel Traffic Services can provide information; make recommendations; issue orders to vessels to specify times of entry, movement, or departure; restrict operations as necessary for safe operation under the circumstances; or take other action necessary to control vessel traffic and the safety of the port or of the marine environment. ${ }^{267}$ Each service has its own requirements applicable to vessels within the service area. ${ }^{268}$ Vessels that fail to comply with any applicable VTS requirement or regulations promulgated under the authority of PWSA may be denied entry into US navigable waters. ${ }^{269}$

Under US law, a VTS may provide for a "VTS Special Area"-a waterway within the area subject to the VTS where special operating requirements or restrictions apply. ${ }^{270}$ VTS Special Areas are designed to preserve the safety of adjacent waterfront structures, ensure safe transit of vessels, or protect the marine environment. ${ }^{271}$ The Coast Guard may

263. See IMO VTS Guidelines, supra note 248, § 3.2 .2 (providing complete list of justifications for VTSs).

264. IMO VTS Guidelines, supra note $248, \S 2.2 .1$.

265. IMO VTS Guidelines, supra note $248, \S 2.2 .1$.

266. SOLAS, supra note 96 , Reg. V/12.4.

267. 33 C.F.R. $\S 160.5(d)$ (2013); 33 C.F.R. $§ 161.11(b)$ (2013) (in times of congestion, restricted visibility, adverse weather, or other hazardous circumstances, a Vessel Traffic Center can "control, supervise, or otherwise manage traffic, by specifying times of entry, movement or departure to, from, or within a VTS area").

268. See Vessel Traffic Service and Vessel Movement Reporting System Areas and Reporting Points, 33 C.F.R. §161 Subpart C, (2013) (describing rules for each service area in the United States); 33 C.F.R. $\S 161.3$ ("The provisions of this subpart shall apply to each VTS User and may also apply to any vessel while underway or at anchor on the navigable waters of the United States within a VTS area, to the extent the VTS considers necessary.").

269. 33 U.S.C. $\S \S 1228(a)(4), 1232(\mathrm{e})$ (2013); 33 C.F.R. $\S 160.107$ (2013). Even where a law expressly sanctions a departure from the ordinary rules, in the interest of safety, courts may narrowly construe the authority to depart; see also Crowley Marine Servs. Inc. v. Maritrans Inc., 447 F.3d 719, 727 (9th Cir. 2006) (interpreting COLREGs Rule 2(b) and limiting any departure from the rules for special circumstances to cases where the departure is "necessary to avoid immediate danger" and thus excluding departure by agreement).

270. See 33 C.F.R. $§ 161.13$ (2013) (VTS Special Area operating requirements); MARINE SAFETY MANUAL, supra note 229, at 1-45.

271. MARINE SAFETY MANUAL, supra note 229, at 1-45. 
establish these areas by federal regulations. ${ }^{272}$

VTS Special Areas are similar to Regulated Navigation Areas, except VTS Special Areas may only be established by the Coast Guard Commandant within a VTS. ${ }^{273}$ RNAs may be established by the district commander anywhere within the navigable waters of the United States. ${ }^{274}$

Vessel traffic centers operate vessel traffic services. ${ }^{275}$ The Coast Guard now operates ten vessel traffic centers and participates in two others that are organized and staffed through public-private partnerships. ${ }^{276}$ "VHFFM communications network forms the basis of most major services."277 Centers may also implement Vessel Movement Reporting Systemsmandatory reporting systems used to monitor and track vessel movements. ${ }^{278}$ "A typical vessel movement reporting system (VMRS) requires covered vessels to provide the VTS with a sailing plan, periodic position reports, a final report, and notification if the vessel deviates from its sailing plan." 279

\subsection{Aids to Navigation}

Parties to SOLAS are supposed to provide for Aids to Navigation when justified by the volume of traffic and degree of risk. ${ }^{280}$ "Aids to

272. See 33 U.S.C. $\$ 1228$ (2013) (providing authority for the Secretary to prescribe conditions for entry to ports in the United States); 33 C.F.R. §161 Subpart C (2013) (listing Vessel Traffic Service and Vessel Movement Reporting System Areas and Reporting Points).

273. MARINE SAFETy MANUAL, supra note 229, at 1-46.

274. MARINe SAFETy MANUAL, supra note 229, at 1-46.

275. 33 C.F.R. $\$ 161.2$ (2013) (definition of vessel traffic center).

276. The ten VTSs operated by the Coast Guard are in New York, Louisville, HoustonGalveston, Berwick Bay (Morgan City), St. Mary's River, San Francisco, Puget Sound, Prince William Sound, Port Arthur, and Lower Mississippi River (New Orleans). The Coast Guard jointly operates VTS centers in Los Angeles-Long Beach and Tampa, Florida (and to some extent the Lower Mississippi River VTS) in conjunction with nongovernment entities; and it operates the Cooperative Puget Sound VTS with Canada. See 33 C.F.R. §161 Subpart C (2013); Vessel Traffic Services, U.S. COAST Guard NAvigation CTR., http://www.navcen.uscg.gov/?pageName=vtsMain (last visited Nov. 7, 2013, archived at http://perma.cc/X5HF-XJ8B).

277. Vessel Traffic Services, supra note 276.

278. See 33 C.F.R. § 161.2 (2013) (defining Vessel Movement Reporting Systems). Vessel Movement Reporting Systems cover power-driven vessel of forty meters or more in length, while navigating; towing vessels of eight meters (approximately twenty feet) or more in length, while navigating; and vessels certificated to carry fifty or more passengers for hire, when engaged in trade. 33 C.F.R. $§ 161.16$ (2013).

279. Craig H. Allen, Hiding Behind "Tradition"? Should U.S. Vessel Traffic Centers Exercise Greater Direction and Control Over Vessels in Their Areas?, 34 TuL. MAR. L.J. 91, $112 \mathrm{n} .103$ (2009).

280. SOLAS, supra note 96, Reg. V/13.1. Aids should be established based on the appropriate recommendations and guidelines of IALA and SN/Circ.107-Maritime Buoyage 
Navigation can provide vessels with the same type of information drivers get from street signs, stop signals, road barriers, detours, and traffic lights." 281 These aids may be lighted structures, beacons, day markers, range lights, fog signals, landmarks, or floating buoys. ${ }^{282}$ Each has a purpose and helps in determining location, getting from one place to another, or staying out of danger. ${ }^{283}$

The U.S. Coast Guard maintains a Federal Aids to Navigation System "consisting of visual, audible, and electronic signals which are designed to assist" vessel navigation. ${ }^{284}$ "This system employs a simple arrangement of colors, shapes, numbers, and light characteristics to mark navigable channels, waterways, and obstructions adjacent to [the signals]. ${ }^{.285}$ The Coast Guard considers whether to establish new Aids to Navigation based on a number of factors, including the need to prevent collisions, the amount and nature of the traffic, the cost of the system compared to the public benefit, and the preservation of natural resources. ${ }^{286}$

Appendix 3 contains a list of Coast Guard-maintained aids to navigation in the Bering Strait Region and a map of buoys and towers maintained by NOAA and private entities.

\subsection{Tracking Technology}

Long Range Identification and Tracking (LRIT) systems and Automated Identification Systems (AIS) allow communication between vessels and on-shore observers, with the objective of avoiding collisions, maintaining safe distance from maritime hazards, locating vessels in distress, and assisting in search and rescue efforts. Under both systems, vessels carry hardware which actively transmits information regarding

\footnotetext{
System. See SOLAS, supra note 96, Reg. V/13.2.

281. Aids to Navigation Team Kodiak, U.S. COAST GUARD, http://www.uscg.mil/d17/antkodiak/ (last updated Sept. 8, 2008, archived at http://perma.cc/AJU8-7VRG).

282. Id.

283. Id.

284. See Navigation Rules, U.S. COAST GUARD, http://www.uscgboating.org/regulations/navigation_rules.aspx (last visited Nov. 9, 2013, archived at http://perma.cc/QC37-3KQM). The Coast Guard has authority under 14 U.S.C. $\S$ 81 to establish aids to navigation in the United States, the waters above the continental shelf, the territories and possessions of the United States, and beyond the territorial jurisdiction of the United States at places where naval or military bases of the United States are or may be located. The Coast Guard also permits private aids to navigation. 33 C.F.R. $\S 62.1$ (2013).

285. Aids to Navigation Team Kodiak, U.S. COAST GUARD, http://www.uscg.mil/d17/antkodiak/ (last updated Sept. 8, 2008, archived at http://perma.cc/N7AA-PJNY).

286. U.S. Coast Guard Commandant, Notice 16500: Aids to Navigation Manual ADMINISTRATION 3-5 (Mar. 2, 2005), archived at http://perma.cc/N92S-MSYJ (establishment criteria); see also id. at 2-2, 2-5 (discussing preparation of Form CG-3213, which is used to justify modifications to the Coast Guard's aids to navigation system).
} 
vessel identify and location. LRIT enables observers to identify and track vessels over a broad geographic area through the use of satellites. ${ }^{287}$ AIS is a line-of-sight broadcast system which transmits information over VHF radio bands and can be received by any receiver within the transmission range. ${ }^{288}$ Both systems are required in US waters for certain vessels subject to US regulations. ${ }^{289}$

\subsubsection{Long Range Identification and Tracking}

SOLAS requires cargo vessels of 300 gross tons or more, passenger ships, high-speed craft, and mobile offshore drilling rigs to implement LRIT. ${ }^{290}$ Through this system, vessels must automatically transmit their identity, their position in latitude and longitude, and the date and time of the position provided to an orbiting satellite. ${ }^{291}$ Information received by the satellite is transmitted to land-based data centers in states that are entitled to receive the information under SOLAS, including the vessel's flag state, the port state the vessel will enter, and coastal states within 1,000 miles of the vessel. ${ }^{292}$ The land-based data centers can then share the information with

287. 73 Fed. Reg. 23309, 23312 (Apr. 29, 2008) (codified at 33 C.F.R. pt. 169); Long Range Identification and Tracking (LRIT), InTERNATIONAL MARITIME ORGANIZATION, http://www.imo.org/blast/mainframe.asp?topic_id=905 (last visited Nov. 11, 2013, archived at http://perma.cc/UCY2-7N47).

288. Automatic Identification System Overview, U.S. COAST GuARD NAVIGATION CENTER, http://www.navcen.uscg.gov/?pageName=AISmain (last updated June 4, 2013, archived at http://perma.cc/6RPV-PD7Q).

289. 46 U.S.C. $\S 70114$ (2013); 33 C.F.R. § 164.46 (2013) (requiring the following vessels to have AIS when on an international voyage: self-propelled vessels of sixty-five feet or more in length, other than passenger and fishing vessels, in commercial service; passenger vessels of 150 tons or more; all tankers; and vessels (other than passenger vessels or tankers) of 300 tons or more; and requiring the following vessels to have AIS when passing through a VTS: self-propelled vessels of sixty-five feet or more in length, other than fishing vessels and passenger vessels certificated to carry less than 151 passengers-for-hire, in commercial service; towing vessels of twenty-six feet or more in length and more than 600 horsepower, in commercial service; and passenger vessels certificated to carry more than 150 passengersfor-hire); 33 C.F.R. $§ 169.205$ (2013) (requiring passenger ships, cargo ships of 300 tons or more, and mobile offshore units not engaged in drilling operations to transmit position reports while engaged on an international voyage).

290. SOLAS, supra note 96, Regs. V/19-1.4.1, 19-1.2.1, amended by IMO Res. MSC.202(81) (May 19, 2006).

291. SOLAS, supra note 96, Reg. V/19-1-5, amended by IMO Res. MSC.202(81) (May 19, 2006); see generally Long-Range Identification and Tracking (LRIT), INTERNATIONAL MARITIME ORGANIZATION, http://www.imo.org/OurWork/Safety/Navigation/Pages/LRIT.aspx (last visited Nov. 9, 2013, archived at http://perma.cc/H7W3-Z83U).

292. See SOLAS, supra note 96, Reg. V/19-1-8.1.3, amended by IMO Res. MSC.202(81) (May 19, 2006). 
an international data exchange. ${ }^{293} \mathrm{~A}$ foreign state is not entitled to receive information about a vessel located within the territorial waters of the vessel's flag state. ${ }^{294}$ Also, states that are not a party to SOLAS are not entitled to receive information. ${ }^{295}$

Inmarsat-C, a satellite-based system that provides automatic transmissions by LRIT as well as manual transmissions, ${ }^{296}$ is often used in ship reporting systems. ${ }^{297}$

US-flagged ships are generally required to transmit periodic ${ }^{298}$ LRIT position reports to the U.S. National Data Center when traveling internationally. ${ }^{299}$ Foreign-flagged ships must transmit LRIT position reports to the National Data Center after they announce their intention to enter a US port, or when the ship is within 1,000 nautical miles of the baseline of the United States. ${ }^{300}$ Ships with AIS operating only within twenty nautical miles of the United States baseline are exempt from LRIT requirements. ${ }^{301}$

The non-profit organization Marine Exchange of Alaska provides LRIT in Alaska, ${ }^{302}$ and it is available throughout the Bering Strait Region. ${ }^{303}$

293. U.S. Gov't Accountability Office, GAO-09-337 Maritime Security: Vessel Tracking Systems Provide Key Information, But the Need for Duplicate Data SHOULD BE REVIEWED 17 (2009), archived at http://perma.cc/5AZA-Y2QA [hereinafter GAO REPORT].

294. See SOLAS, supra note 96, Reg. V/19-1-8.1.4, amended by IMO Res. MSC.202(81) (May 19, 2006). For example, Canadian authorities are not entitled to receive information about U.S.-flagged vessels operating in the U.S. territorial sea.

295. SOLAS, supra note 96, Reg. V/19-1-8.1.

296. Inmarsat-C, mini-C, ZORA ADVANCED TeChNOLOGIES, http://www.zora.ru/eng/?a=show\&id=265\&nodec=1 (last visited Jan. 20, 2014, archived at http://perma.cc/FD85-JP5C).

297. E.g., West European Tanker Reporting System (WETREP) 93.4 .3 , supra note 208 (Inmarsat-C and VHF radio calls); Papahānaumokuākea Marine National Monument PSSA (CORAL SHIPREP) $\uparrow 3.4 .1$, supra note 208 (Inmarsat-C and email); In the Galapagos PSSA (GALREP) $\{3.1$, supra note 208 (Inmarsat-C, phone, fax, and email).

298. Under 33 C.F.R. $\S 169.230$, a ship's LRIT equipment must transmit position reports at six-hour intervals unless a more frequent interval is requested remotely by an LRIT Data Center. 33 C.F.R. $\S 169.230$ (2013). See also 33 C.F.R. $\S 169.210$ (2013) (U.S. flag ships "engaged in an international voyage must transmit position reports wherever they are located.")

299. 33 C.F.R. $§ 169.205$ (2013) (requiring passenger ships, cargo ships of 300 gross tonnage or more, and mobile offshore units not engaged in drilling operations to transmit position reports while engaged in an international voyage).

300. 33 C.F.R. $\$ 169.210$ (b)-(c); see also GAO REPORT, supra note 293, at 5-6 n.5.

301. 33 C.F.R. $\S 169.235$ (2013).

302. See Marine Exchange of Alaska's Vessel Tracking System-Introduction, MARINE EXCHANGE OF ALASKA, http://www.mxak.org/vtrack/vtrack_intro.html (last visited Nov. 9, 2013, archived at http://perma.cc/S6BR-ZVN6).

303. Interview with Ed Haney, Maritime Specialist, Marine Exchange of Alaska (Oct. 2, 
The Global Maritime Distress and Safety System (GMDSS), based upon a combination of satellite and terrestrial radio services, facilitates search and rescue communications between ships and shore-based rescue coordination centers. ${ }^{304}$ It has been used off the coast of Alaska, but polar areas north of the Bering Sea Range may be out of range of the satellites. ${ }^{305}$ SOLAS requires all passenger ships and all cargo ships over 300 tons on international voyages to carry LRIT equipment that can interface directly with GMDSS. ${ }^{306}$

\subsubsection{Automated Identification System}

VHF-based AIS equipment automatically transmits information about a vessel to receivers within range of its broadcast, allowing vessels to be tracked when "operating in coastal areas, inland waterways, and ports." AIS receivers may be located on vessels, land-based stations, or elsewhere. ${ }^{308}$ Since AIS can be received by anyone with a receiver, data can easily be received by any country bordering a reporting area. The Marine Traffic Project and other non-government entities ${ }^{309}$ publish AIS data from ships around the world on the Internet, ${ }^{310}$ allowing anyone with Internet access to view AIS data.

For AIS to automatically and accurately transmit information, the vessel operator must program the system with data from the vessel's radio station license or other official documents. ${ }^{311}$ Once programmed, an AIS

2012).

304. GAO REPORT, supra note 293, at 30-31; Global Maritime Distress and Safety System, U.S. COAST GuARD NAVIGATION CENTER, http://www.navcen.uscg.gov/?pageName=GMDSS (last updated Aug. 15, 2013, archived at http://perma.cc/5Y7F-6KGZ).

305. GAO REPORT, supra note 293, at 31.

306. SOLAS, supra note 96, Reg. IV; see also SOLAS, supra note 96, Reg. V/19-1-2.1 (requiring LRIT equipment onboard ships to interface directly to the ship borne Global Navigation Satellite System (GNSS) equipment or to have an internal positioning capability), amended by MSC.202 (81).

307. GAO REPORT, supra note 293, at 2.

308. See GAO REPORT, supra note 293, at 2; Marine Exchange of Alaska's Vessel Tracking System-Introduction, MARINE Exchange OF ALASKA, http://www.mxak.org/vtrack/vtrack_intro.html (last visited Nov. 9, 2013, archived at http://perma.cc/6LDH-HB5Q).

309. E.g., About, AISLIVE, http://www.aislive.com/Company.html (last visited Nov. 9, 2013, archived at http://perma.cc/5BDF-VBQR); About, FLEETMON, http://www.fleetmon.com/about (last visited Nov. 9, 2013, archived at http://perma.cc/ZZ32EKYK).

310. See Frequently Asked Questions, MARINE Traffic, http://www.marinetraffic.com/ais/faq.aspx?level1=160 (last visited Nov. 9, 2013, archived at http://perma.cc/9TTZ-ZM6Q); see also Current Conditions in Ports, MARINE TRAFFIC, www.marinetraffic.com/ais/datasheet.aspx?datasource=PORTS_CURRENT\&level $0=300$ (last visited Nov. 9, 2013, archived at http://perma.cc/F7Q3-SU5M).

311. AIS Frequently Asked Questions, U.S. COAST GuARD Navigation Center, 
unit autonomously broadcasts two different AIS messages: a "position report" indicating the vessel's position, course, speed, navigation status; and a "static and voyage-related report," which includes the vessel's name, dimensions, and type, as well as its destination and estimated time of arrival. ${ }^{312}$ Position reports are broadcasted every few seconds for moving vessels and every few minutes for anchored vessels. ${ }^{313}$ Static and voyagerelated reports are sent every six minutes. ${ }^{314}$

AIS can transmit a greater volume of data and does so more frequently than LRIT systems, ${ }^{315}$ but over a more limited horizontal range (typically between fifteen and forty nautical miles). ${ }^{316}$ The AIS signal has a much farther vertical range (around 200 nautical miles), and satellite-based AIS is now being developed to expand the system. ${ }^{317}$ Satellite-based AIS does not require special technology to be added to ship fleets, and it could permit coastal authorities to review data on all ships in their region, even when the vessels are in mid-ocean. ${ }^{318}$

SOLAS requires all passenger vessels, all vessels of 300 gross tons and larger on international voyages, and all cargo vessels of 500 gross tons not on international voyages to be fitted with AIS equipment. ${ }^{319}$ The Coast Guard refined these requirements to generally include commercial vessels sixty-five feet or longer, passenger vessels of 150 tons or more, and all tankers, either on international voyages or in VTS areas. ${ }^{320}$ Vessels with

http://www.navcen.uscg.gov/?pageName=AISFAQ (last updated Oct. 30, 2013, archived at http://perma.cc/EUE5-GDHC).

312. Id.

313. Id.

314. Id.

315. Long Range Identification and Tracking of Ships, 73 Fed. Reg. 23309, 23312 (Apr. 29, 2008) (codified at 33 C.F.R. pt. 169); GAO REPORT, supra note 293, at 8, 24-25.

316. Frequently Asked Questions, MARINE TRAFFIC, http://www.marinetraffic.com/ais/faq.aspx?level1=160 (last visited Nov. 9, 2013, archived at http://perma.cc/5UAF-ML64) ("Normally, vessels with an AIS receiver connected to an external antenna placed on 15 meters above sea level, will receive AIS information within a range of fifteen to twenty nautical miles. Base stations at a higher elevation may extend the range up to $40-60 \mathrm{~nm} . . . ")$ (alteration added). The U.S. Coast Guard's Nationwide AIS installed in ports and along coastal areas receives data from up to twenty-four nautical miles offshore. Nationwide Automatic Identification System, U.S. COAST GUARD, http://www.uscg.mil/acquisition/nais/ (last updated Sept. 19, 2013, archived at http://perma.cc/JEY8-5KHX).

317. AWT: First Service Using Global AIS for Accurate Vessel Monitoring, MARINELINK.COM (Sept. 13, 2011), http://www.marinelink.com/news/monitoringaccurate340374.aspx, archived at http://perma.cc/CDL4-YMQR.

318. Peter de Selding, Tracking Ships from Space: 2 Satellite Rivals Race To Become First in an Emerging Field, DEFENSE News (Apr. 10, 2011), http://www.defensenews.com/article/20110410/DEFFEAT01/104100302/Tracking-ShipsFrom-Space, archived at http://perma.cc/FX98-79QP.

319. SOLAS, supra note 96 , Regs. V/19.2.4, 19.1.

320. See, e.g., 46 U.S.C. $§ 70114$ (2013) (requiring certain vessels to carry automatic identification system equipment); 33 C.F.R. $§ 164.46$ (2013). 
AIS that transmit information automatically are not required to manually submit position reports when in VTS areas. ${ }^{321}$

Much of the AIS in existence is commercially provided, although the U.S. Coast Guard has been implementing and expanding a Nationwide AIS (NAIS). ${ }^{322}$ Since September 2007, the Coast Guard has operated NAIS at fifty-eight US ports and eleven coastal areas (not including Alaska), ${ }^{323}$ which receive data from up to twenty-four nautical miles offshore. ${ }^{324}$

Some ship reporting systems rely on AIS networks to obtain information on ship identity and position, although VHF voice reports and other transmission mechanisms may be required to provide additional information. $^{325}$ One example is the ship reporting system for the international Strait of Gibraltar. This system requires VHF voice reports to be sent to centers in both Tarifa, Spain, and Tangier, Morocco. ${ }^{326}$ Both these centers monitor traffic using radar as well as AIS. ${ }^{327}$

The commercial AIS receiver network established by the Marine Exchange of Alaska covers all traffic operating in the US Arctic region approaching or leaving the Bering Strait and the Aleutian Archipelago. ${ }^{328}$ The network provides traffic reports and location data to the U.S. Coast Guard and state emergency responders of all ships approaching state waters. ${ }^{329}$ AIS receivers are currently located in Gambell and Savoonga on St. Lawrence Island; Point Hope, Pont Lay, Wainwright, and Barrow in the North Slope Borough; Kivalina and Kotzebue in the Northwest Arctic Borough; Wales and Nome on Seward Peninsula; and between St. Michael and Emmonak south of Nome. ${ }^{330}$

321. See 33 C.F.R. $§ 161.21$ (2013).

322. GAO REPORT, supra note 293, at 9.

323. See Acquisition Directorate, U.S. COAST GUARD, http://www.uscg.mil/acquisition/map.asp (last updated Oct. 30, 2013, archived at http://perma.cc/K63E-M5QY) (showing states that have NAIS).

324. Nationwide Automatic Identification System, U.S. COAST GUARD, http://www.uscg.mil/acquisition/nais/ (last updated Sept. 19, 2013, archived at http://perma.cc/5W2-VFAD).

325. E.g., Great Belt Reporting System, supra note 209, $₫ \uparrow \mid 3.1,7.4 .1$.

326. Gibraltar Reporting System, supra note $200, \uparrow 3$.

327. Gibraltar Reporting System, supra note 200, $₫ \uparrow 3.5,7$.

328. Protecting U.S. Sovereignty: Coast Guard Operations in the Artic: Hearing Before the House Transportation and Infrastructure Subcommittee on Coast Guard and Maritime Transportation Hearing, 112th Cong. 63(Dec. 1, 2011) (testimony of Mead Treadwell, Lt. Gov. Alaska); AIS coverage reaches the Bering Strait. Interview with Ed Haney, Maritime Specialist, Marine Exchange of Alaska (Oct. 2, 2012).

329. Protecting U.S. Sovereignty: Coast Guard Operations in the Artic: Hearing Before the House Transportation and Infrastructure Subcommittee on Coast Guard and Maritime Transportation Hearing, 112th Cong. 63 (Dec. 1, 2011) (testimony of Mead Treadwell, Lt. Gov. Alaska).

330. Marine Exchange of Alaska's Vessel Tracking System-Introduction, MARINE EXCHANGE OF ALASKA, http://www.mxak.org/vtrack/vtrack_intro.html (last visited Nov. 9, 


\subsubsection{Vessel Monitoring Systems for Fisheries}

Since 1988, NMFS has used satellite-based Vessel Monitoring Systems (VMS) for enforcement and resource management purposes. ${ }^{331}$ Aside from the vessel monitoring requirements for navigational and security purposes under SOLAS, certain fishing vessels are required to carry NMFS-approved transmitters that automatically transmit vessel position to NMFS through a communications provider. ${ }^{332}$

The position information is provided to NOAA in near real-time no matter where the vessel is located in the world. ${ }^{333}$ The Marine Exchange of Alaska provides VMS communications in Alaska. ${ }^{334}$

\subsection{Notice of Arrival}

IMO's mandatory International Ship and Port Facilities Security Code (ISPS Code), which is linked to chapter XI-2 of the SOLAS Convention, ${ }^{335}$ applies to all commercial vessels over 500 tons engaged in international trade, as well as mobile offshore drilling units. ${ }^{336}$ The Code requires public and private ports and terminals to be secure, and ships may be required to provide notice and information to the maritime authorities of the host state. ${ }^{337}$ Ships engaged in cargo operations, support services, or cruises in the Arctic have to comply with the ISPS Code and cooperate with port and terminal security. ${ }^{338}$

The United States has implemented advance notice of arrival

2013, archived at http://perma.cc/QV8Z-CWF7).

331. See U.S. COAST GuARD AND NOAA, Report to CONGRess: Fisheries MANAGEMENT SYSTEMS AND DATA SHARING 2 (2007), archived at http://perma.cc/SXR39WVF.

332. 50 C.F.R. $\S 679.28(f)(1)$ (2013). Transmitters must be transmitting when fishing vessels are operating in reporting areas within the Exclusive Economic Zone of Alaska while engaged in fisheries requiring VMS pursuant to a Federal Fisheries Permit. See id. $\S$ 679.28(f)(6).

333. See U.S. Coast Guard and Nat'l oceanic and Atmospheric Administration, ReP. to Cong.: Fisheries MANAGEMENT Systems AND DATA SHARING 2 (2007), archived at http://perma.cc/6QLQ-GVLB.

334. Interview with Ed Haney, Maritime Specialist, Marine Exchange of Alaska (Oct. 2, 2012).

335. This chapter was adopted at a 2002 convention at the same time that major revisions to SOLAS Chapter V (on ship reporting and routing) were adopted. See IMO Adopts Comprehensive Maritime Security Measures, International Maritime Organization, http://www.imo.org/blast/mainframe.asp?topic_id=583\&doc_id=2689\#solas (last visited Feb. 15, 2014, archived at http://perma.cc/ELD7-5GEX).

336. AMSA REPORT, supra note 2, at 62; FAQ on ISPS Code and Maritime Security, INTERNATIONAL MARITIME ORGANIZATION, http://www.imo.org/blast/mainframe.asp?topic_id=897\#who (last visited Feb. 15, 2014, archived at $\mathrm{http}: / /$ perma.cc/3GQW-GLWV).

337. AMSA REPORT, supra note 2 , at 62

338. AMSA REPORT, supra note 2, at 63. 
requirements consistent with those of the ISPS Code. ${ }^{339}$ The basic requirement is that notice must be given to the National Vessel Movement Center between twenty-four and ninety-six hours (depending on the duration of the trip) before arrival in a United States port. ${ }^{340}$ The requirement applies to most US and foreign vessels over 300 tons bound for or departing from ports or places in the United States. ${ }^{341}$ Notice can be submitted by internet, fax, or phone. ${ }^{342}$

\subsection{Special and Protected Areas}

\subsubsection{Special Areas}

MARPOL provides for "special areas" where mandatory measures may be adopted for pollution prevention. ${ }^{343}$ To qualify as a special area under MARPOL, the area's oceanographic, ecological, and vessel traffic conditions must merit "special mandatory methods for the prevention of sea pollution." 344 Oceanographic conditions include circulation patterns, temperature, salinity stratification, low flushing rates, extreme ice, and adverse winds that could cause harmful substances to be concentrated or retained in the waters or sediments of the area. ${ }^{345}$ Ecological conditions include depleted, threatened or endangered marine species; areas of high natural productivity; spawning, breeding and nursery areas; areas representing migratory routes for sea-birds and marine mammals; rare or fragile ecosystems; and critical habitats and/or areas of critical importance for the support of large marine ecosystems. ${ }^{346}$ The area must experience a degree of traffic whereby conformance with the usual requirements of

339. AMSA RePORT, supra note 2, at 62; see also 33 C.F.R. 160 Part C; 68 Fed. Reg. 393292, 39294 (July 1, 2003) (Coast Guard found that the harmonization of U.S. regulations with the 2002 ISPS Code and the need to update notice of arrival requirements and institute measures for the protection of U.S. maritime security as soon as practicable furnished good cause for implementing an interim rule without advanced notice).

340. Navigation and Navigable Waters, 33 C.F.R. $\$ 160.212$ (2003).

341. See Navigation and Navigable Waters, 33 C.F.R. $\S 160.202$ (2005); 33 C.F.R. $\S$ 160.203 (2005).

342. Id. $\S 160.210$.

343. See Special Areas under MARPOL, International Maritime Organization, http://www.imo.org/OurWork/Environment/PollutionPrevention/SpecialAreasUnderMARP OL/Pages/Default.aspx (last visited Feb. 15, 2014, archived at http://perma.cc/C6ZF-D56B).

344. MARPOL, supra note 119, at Annex I, Regulation 1(10), Annex II, Regulation 1(7), Annex V, Regulation 1(3) (each providing a similar definition of "special area"); See also MARPOL Guidelines, supra note 116 at Annex 1, $§ 2.1$; Special Areas under MARPOL, INTERNATIONAL MARITIME ORGANIZATION, http://www.imo.org/OurWork/Environment/PollutionPrevention/SpecialAreasUnderMARP OL/Pages/Default.aspx (last visited Feb. 15, 2014) (discussing special areas).

345. MARPOL Guidelines, supra note 120, at Annex 1, § 2.4.

346. MARPOL Guidelines, supra note 120, at Annex 1, § 2.5. 
MARPOL would be insufficient to protect the area from pollution. ${ }^{347}$ A state may also suggest other factors to justify Special Area designation. ${ }^{348}$

To obtain Special Area designation, a state must submit a proposal to IMO explaining how the area fulfills the criteria for the designation of special areas under the relevant MARPOL annex. ${ }^{349}$ A Special Area can be proposed for the waters of one or more states, or even an entire enclosed or semi-enclosed area. ${ }^{350}$ If two or more states have a common interest in the area, they would presumably submit a joint proposal. ${ }^{351}$ If IMO approves the designation, it becomes effective only when there are adequate reception facilities in the area to receive the particular harmful substance from affected ships. ${ }^{352}$

A special area could be designated to implement specific pollution prevention measures in the Bering Sea Region, although this would have little impact on ship routing and communications. Regulations associated with Particularly Sensitive Sea Areas, discussed in the next section, would allow for more control over routing and communications.

\subsubsection{Particularly Sensitive Sea Areas}

A Particularly Sensitive Sea Area (PSSA) is "an area that needs special protection through action by IMO because of its significance for recognized ecological, socio-economic, or scientific attributes where such attributes may be vulnerable to damage by international shipping activities." 353

347. MARPOL Guidelines, supra note 120, at Annex 1, § 2.6.

348. MARPOL Guidelines, supra note 120, at Annex 1, §§ 2.3, 2.8-2.10.

349. See MARPOL Guidelines, supra note 120, at Annex 1, § 3 (describing specifically what must be submitted, including a definition of the area proposed for designation, the area's precise geographical coordinates, the relevant annex, a description of the area's special characteristics and environmental pressures, existing protection measures, an analysis of how the area fulfills the criteria for the designation, and information on the availability of adequate reception facilities).

350. MARPOL Guidelines, supra note 120, at Annex 1, § 2.2.

351. This is not specifically stated in the MARPOL Guidelines for Special Areas, although it is required for PSSAs and other IMO-approved designations. In 2009, 2010 and 2011 the Contracting Parties of the Helsinki Commission (Denmark, Estonia, European Union, Finland, Germany, Latvia, Lithuania, Poland, Russia, and Sweden) "submitted a joint proposal to IMO ... to designate the Baltic Sea as a special area for sewage discharges from passenger ships." Cooperation Platform on Port Reception Facilities in the Baltic Sea, HelsinKI COMMISSION, http://helcom.navigo.fi/shipping/waste/en_GB/waste/ (last visited Feb. 15, 2014, archived at http://perma.cc/D68E-C67K) (alteration added). IMO adopted the proposal in 2011. Id.

352. MARPOL Guidelines, supra note 120, at Annex 1, § 2.7.

353. Revised Guidelines for the Identification and Designation of Particularly Sensitive Sea Areas, International Maritime Organization Res. A.982(24) $\S 1.2$ (Dec. 1, 2005) [hereinafter PSSA Guidelines]. 
PSSAs are designated along with specific measures (called "Associated Protective Measures"), which could include the designation of the same area as a Special Area subject to pollution controls; the adoption of a ship routing or reporting system near or in the area; or other measures aimed at protecting the area against environmental damage from ships, provided that they have an identified legal basis. ${ }^{354}$

To be identified as a PSSA, a proposed area must meet at least one of the ecological, socio-economic, or scientific criteria identified by IMO. ${ }^{355}$ Ecological criteria include factors such as the uniqueness or rarity of the area; the presence of critical habitat in the area; the degree to which the area is representative of a certain habitat type; the area's diversity and productivity; the presence of spawning or breeding grounds or migratory routes in the area; or the naturalness, integrity, or fragility of the area. ${ }^{356}$ Social, cultural, and economic criteria include the extent to which people depend on the ecological health of the area for social or economic purposes; the extent to which the area is important for the support of traditional subsistence or food production activities; or the presence of historical or archaeological sites. ${ }^{357}$ Scientific and educational criteria include factors such as whether an area is of particular scientific interest; whether it can provide a baseline for monitoring studies; or whether it provides an outstanding opportunity for education. ${ }^{358}$

In addition to the above criteria, an application for designation of a PSSA must describe the area's vulnerability to damage from international shipping activities. ${ }^{359}$ Vulnerability is based on vessel traffic characteristics, such as the type of maritime activities in the area, the types of vessels that use the area, the characteristics of the vessel traffic, and the extent to which vessels carry harmful substances. ${ }^{360}$ Vulnerability also relates to natural characteristics, such as water conditions, weather conditions, and the presence of potential hazards like sea ice, tidal streams, or ocean currents. ${ }^{361}$ Proposals for PSSA designation can withstand consideration of additional factors, including any history of accidents or stresses from other

354. Id. § 6; see also Jon M. Van Dyke \& Sherry P. Broder, Particular Sensitive Sea Areas; Protecting the Marine Environment in the Territorial Seas and Exclusive Economic Zones, 40 DENV. J. INT'L L. \& POL'Y 472, 478 (2011) (suggesting that measures may include vessel traffic services).

355. PSSA Guidelines, supra note $353, \S 4.4$.

356. PSSA Guidelines, supra note 353, $\S \S 4.4 .1-4.4 .11$ (listing ecological criteria).

357. PSSA Guidelines, supra note 353, $\S \S 4.4 .12-4.4 .14$ (listing social, cultural, and economic criteria).

358. PSSA Guidelines, supra note 353, $\S \S 4.4 .15-4.4 .17$ (listing scientific and educational criteria).

359. PSSA Guidelines, supra note $353, \S 5.1$.

360. PSSA Guidelines, supra note $353, \S \S 5.1 .1-5.1 .4$ (listing vessel traffic characteristics).

361. PSSA Guidelines, supra note 353, $\S \S 5.1 .5-5.1 .7$ (listing natural factors). 
environmental sources. ${ }^{362}$

To establish a PSSA, a nation must submit an application to IMO proposing an area for PSSA designation and adopt associated protective measures. ${ }^{363}$ If multiple countries have a common interest in an area, they should submit a coordinated proposal to IMO for consideration. ${ }^{364}$ The PSSA and protective measures are effective as soon as possible after IMO approves the proposal. ${ }^{365}$

There currently are no PSSAs in Arctic waters. ${ }^{366}$

\section{EXAMPLES OF SHIP REGULATORY SYSTEMS IN PLACE}

\subsection{Torres Strait-Ship Reporting System, Vessel Traffic Service, and Long Range Tracking Identification System}

The Torres Strait is an international strait between Australia and

362. PSSA Guidelines, supra note $353, \S \S 5.2 .2,5.2 .4$ (referring to other information that could be used).

363. See PSSA Guidelines, supra note $353, \S 3$ (process for designation of PSSAs), $§ 7$ (procedure for designating PSSAs). IMO has issued several resolutions regarding PSSA designation in addition to the 2005 PSSA Guidelines. See Guidelines for the Designation of Special Areas and the Identification of Particularly Sensitive Areas, International Maritime Organization Resolution A. 720 (17) (Nov. 6, 1991); Procedures for the Identification of Particularly Sensitive Sea Areas and the Adoption of Associated Protective measures and Amendments to the Guidelines Contained in Resolution A.720(17), International Maritime Organization Resolution A. 885(21) (Nov. 25, 1999); Guidelines for the Designation of Special Areas Under MARPOL 73/78 and Guidelines for the Identification and Designation of Particularly Sensitive Sea Areas, International Maritime Organization Resolution A.927 (22) (Nov. 19, 2002) (Assembly Adoption of both Guidelines for the Designation of Special Areas under MARPOL and Guidelines for the Identification and Designation of Particularly Sensitive Sea Areas).

364. PSSA Guidelines, supra note 353, §3.1. IMO’s Marine Environment Protection Committee analyzes the application, hears presentations from the nominating government(s), and receives reports from IMO technical groups. After doing so, it may designate the area "in principle" and inform the appropriate IMO committees and subcommittees. See PSSA Guidelines, supra note 353, $\S \S 8.3 .1-8.3 .3$. The Marine Environment Protection Committee makes the final PSSA designation only after the appropriate committees or the IMO Assembly approve the associated protective measures for the area. PSSA Guidelines, supra note $353, \S 8.3 .4$. If the associated protective measures are not approved, IMO may reject the proposal entirely or request that the proposing government submit new proposals for protective measures. See Markus J. Kachel, Particularly Sensitive Sea Areas: The IMO's Role in Protecting Vulnerable Marine Areas Annex 8.3.1.4 (Jürgen Basedow et al. eds., 2008) (Doctoral thesis, University of Hamburg).

365. PSSA Guidelines, supra note $353, \S 8.5$.

366. See Particularly Sensitive Sea Areas, International Maritime Organization, www.imo.org/OurWork/Environment/PollutionPrevention/PSSAs/Pages/Default.aspx (last visited Feb. 15, 2014, archived at http://perma.cc/P54D-LSXB) (listing currently designated PSSAs). 
Papua New Guinea, in the waters along the Great Barrier Reef. ${ }^{367}$ Water depths are often shallow, and the area is subject to monsoon climate with tropical storms and cyclones. ${ }^{368}$ Traffic is not heavy relative to other international straits, but consists of many fishing vessels, tourist vessels and recreational craft that pose collision risks. ${ }^{369}$

IMO adopted Australia's proposal for a Torres Strait Ship Reporting System (REEFREP) in 1996 as a mechanism to enhance navigational safety, reduce the risk of shipping incidents and minimize ship pollution within the Great Barrier Reef and Torres Strait. ${ }^{370}$

The reporting system is mandatory for ships fifty meters or greater in length, ships carrying bulk hazardous or potentially polluting cargo, and ships towing or pushing vessels in the aforementioned categories. ${ }^{371}$ Reports are sent to the REEFREP Vessel Traffic Service Center ${ }^{372}$ at least two hours prior to entering the REEFREP area from the outside or when sailing from a port within the area. ${ }^{373}$

Within an hour of entering the REEFREP area, ships must provide a passage plan including vessel details, pilot information, and route/waypoint information. ${ }^{374}$ Inmarsat-C LRIT is the primary mechanism for providing position reports. ${ }^{375}$ Although vessels using this system must still comply with other VHF reporting requirements described in the REEFREP booklet. ${ }^{376}$ Vessels are required to submit reports if they suffer damage or

367. Torres Strait Reporting System, supra note 209, $\llbracket 2$.

368. Great Barrier Reef and Torres Strait Vessel Traffic System (REEFVTS), AUSTRALIAN MARITIME SAFETY AUTHORITY, http://www.amsa.gov.au/navigation/services/gbr-and-torres-strait-vts/ (last visited Jan. 8, 2014, archived at http://perma.cc/DJX7-U7LV). Much of the navigable route through Torres Strait is confined in both width and depth. Entry to the western Torres Strait is through the Varzin Channel with a minimum width of $0.3 \mathrm{~nm}$, and depth of 10.5 meters. Torres Strait Particularly Sensitive Sea Area (PSSA): Strait Facts/Risk Assessment, Australian MARITIME SAFETY AUTHORITY, http://www.amsa.gov.au/environment/legislation-andprevention/torres-strait-pssa/strait-facts/ (last visited Jan. 8, 2014, archived at http://perma.cc/R9NW-KQ26). Passage through central Torres Strait is via Prince of Wales Channel with minimum width of $0.3 \mathrm{~nm}$ and depth of 11.0 meters. Id.

369. Id. (there are approximately 3000 transits of Torres Strait per year by vessels greater than 50 meters, consisting of bulk carriers (38\%), general cargo $(28 \%)$, containers $(15 \%)$, and loaded tankers $(12 \%))$. Id.

370. Australian Maritime Safety Authority, Important Changes to REEFVTS (effective July 1, 2011), archived at http://perma.cc/FFC4-YSXV.

371. Torres Strait Reporting System, supra note 209, $\llbracket 1$.

372. The center is manned 24 hours a day, 365 days a year, and is equipped with a sophisticated traffic information management tool that integrates and assists in analyzing all VHF communications, radar, LRIT, and AIS information relayed to REEFCENTRE. Torres Strait Reporting System, supra note 209, $\uparrow 7.1$.

373. Torres Strait Reporting System, supra note 209, $₫$.3.

374. Torres Strait Reporting System, supra note 209, $\{3.2$.

375. Torres Strait Reporting System, supra note 209, $\{3.3$.

376. Torres Strait Reporting System, supra note 209, $₫ 3.3$. 
significantly deviate from a route, course, or speed previously advised. ${ }^{377}$

The REEFREP system provides vessels information through Inmarsat-C and VHF voice communications ${ }^{378}$ on ship traffic, including potentially conflicting traffic movements; navigational assistance; and maritime safety information, which includes unusual weather conditions. ${ }^{379}$

If reports are not submitted and the ship can be positively identified, then information will be passed to the relevant flag state for investigation and possible prosecution by that state. ${ }^{380} \mathrm{~A}$ failure to report may also be investigated for breach of Australian laws relating to compulsory ship reporting. ${ }^{381}$

In 2004, IMO approved Australia's proposed amendments to REEFREP creating a new VTS (known as REEFVTS) concurrent with the reporting area. ${ }^{382}$ REEFVTS now manages REEFREP from its vessel traffic center in Queensland, Australia, ${ }^{383}$ obtaining from REEFREP information about ship characteristics and their intended passage through the region. ${ }^{384}$ This information, together with the monitoring and surveillance systems used by REEFVTS, assists with the proactive monitoring of ship transit through the Great Barrier Reef and Torres Strait. ${ }^{385}$

REEFVTS is credited with reducing the number of groundings, from one per year between 1997 and 2003 to only one incident between the years 2004 and 2009. ${ }^{386}$ Following a 2010 incident, IMO approved Australia's request to extend the boundaries of the REEFREP mandatory ship reporting system and allow REEFVTS to monitor the extended area. ${ }^{387}$ The changes took effect in July $2011 .^{388}$

The Torres Strait became a Particularly Sensitive Sea Area (PSSA) in

377. Torres Strait Reporting System, supra note 209, $₫ 3.4$.

378. Torres Strait Reporting System, supra note $209, \mathbb{9}$.

379. Torres Strait Reporting System, supra note 209, $\mathbb{\| 4 .}$

380. Torres Strait Reporting System, supra note 209, $₫ 9.1$.

381. Torres Strait Reporting System, supra note 209, $₫ 9.1$.

382. Australian Maritime Safety Authority, Important Changes to REEFVTS (effective July 1, 2011), archived at http://perma.cc/LJG6-5AM7.

383. Australian Maritime Safety Authority, Great Barrier Reef \& Torres Strait Vessel Traffic Service (REEFVTS) User Guide 3, 4 (2011), archived at http://perma.cc/NS46-GYTU. Papua New Guinea does not have VTS centers that receive reports from the area, although it is entitled to receive this LRIT information under SOLAS Reg. V/19.1.8.1. SOLAS, supra note 96, Reg. V/19.1.8.1

384. Great Barrier Reef and Torres Strait Vessel Traffic Service (REEFVTS), AUSTRALIAN MARITIME SAFETY AUTHORITY, http://www.amsa.gov.au/navigation/services/gbr-and-torres-strait-vts/ (last visited Jan. 9, 2014, archived at $\mathrm{http}: / /$ perma.cc/L6KX-PQML)

385. Id.

386. Australian Maritime Safety Authority, Important Changes to REEFVTS, (effective July 1, 2011), archived at http://perma.cc/ZYD8-6YGF.

387. Id.

388. Id. 
July 2005, when IMO approved a joint proposal submitted by Australia and Papua New Guinea. ${ }^{389}$ Two associated protective measures were approved by IMO for application in the Torres Strait - a new two-way shipping route and an extension of the marine pilotage system that has applied in the Great Barrier Reef area since $1990 . .^{390}$

\subsection{United States East Coast-Ship Reporting System, Ship Routing System, and Long Range Tracking Identification System}

Two areas off the east coast of the United States make up a unique ship reporting system designed to protect the endangered North Atlantic right whale from ship strikes. The United States proposed the system to IMO in 1998, based on the areas that form the whale's critical habitat. ${ }^{391}$ The portion off the Massachusetts coast would be effective year-round, while the portion covering the whales' calving grounds off of the eastern Florida coast would operate from November 15 to April $15 .^{392}$ In support of its submission, the United States detailed the collision risks faced by the whales and the steps that it had taken under the Endangered Species Act and Marine Mammal Protection Act to protect the species. ${ }^{393}$

Critics of the proposal argued that it was inconsistent with the purpose of ship reporting systems and would create an undesirable precedent under the terms of the SOLAS Convention. ${ }^{394}$ The United States

389. Torres Strait Particularly Sensitive Sea Area, AuStralian MARITIME SAfetY AUTHORITY, http://www.amsa.gov.au/environment/legislation-and-prevention/torres-straitpssa/ (last visited Jan. 9, 2014, archived at http://perma.cc/7BT9-93QA). Australia and Papua New Guinea cited UNCLOS Art. 42 (allowing states to regulate marine traffic for navigational safety and pollution prevention) as a basis for extending compulsory pilotage. Robert C. Beckman, PSSAs and Transit Passage - Australia's Pilotage System in the Torres Strait Challenges the IMO and UNCLOS, 38 OCEAN DEV. \& INT'L LAW 330 (2007). The joint proposal provided details about the unique and fragile ecosystem in the Torres Strait as well as hazards to shipping and the potential harm of a pollution incident in the strait. $I d$.

390. Torres Strait Particularly Sensitive Sea Area, Australian Maritime SAfety AUTHORITY, http://www.amsa.gov.au/environment/legislation-and-prevention/torres-straitpssa/ (last visited Jan. 9, 2014, archived at http://perma.cc/SV4X-EQL6).

391. See International Maritime Organization Sub-Committee on Safety of NAVIGATION, SHIP REPORTING SYSTEMS Eastern Coast of the United States, Proposal submitted by the United States (Apr. 10, 1998), archived at http://perma.cc/BLX8-EK6J, approved by IMO in December 1998, effective July 1999.

392. See id.

393. Id.

394. Jeffrey P. Luster, The International Maritime Organization's New Mandatory Ship Reporting System for the Northern Right Whale's Critical Habitat: A Legitimate Approach to Strengthening the Endangered Species Act? 46 NAVAL L. REV. 153, 164-65 (1999) (noting that the United States' original legal justification for the ship reporting system was exclusively focused on protecting the right whale, which many IMO member states argued was improper and inconsistent with the purpose of ship reporting systems). 
modified its proposal to reduce concerns that the system would lead to identification of vessels involved in ship-strikes of whales for prosecution, restrain freedom of navigation, and cause a proliferation of similar systems. ${ }^{395}$ Still, the United States contended that species-specific ship reporting was warranted given that (1) the species was immediately endangered with extinction; (2) major international shipping lanes passed through areas of critical habitat for the species' population; and (3) the greatest known threat to survival and recovery of the population was posed by ship strikes. ${ }^{396}$ IMO ultimately agreed with these justifications, ${ }^{397}$ and the reporting system went into effect in $1999 .{ }^{398}$ The ship reporting system applies to ships of 300 tons or more entering Cape Cod Bay, Massachusetts Bay, and the Great South Channel east of Massachusetts, as well as the ninety nautical-mile stretch along the coasts of Florida and Georgia. ${ }^{399}$ The northern reporting area covers much of a pre-existing traffic separation scheme servicing Boston. ${ }^{400}$ When entering the system, ships are required to provide the ship name, call sign or IMO identification number, position, course, speed, route, and destination. ${ }^{401}$ The Coast Guard center informs ships that they are entering an area of critical importance for the protection of the whale; that whales are present; and that ship strikes pose a serious threat to whales and may cause damage to ships. ${ }^{402}$ Ships are requested to report any whale sightings and dead, injured, or entangled marine mammals to the nearest local Coast Guard station. ${ }^{403}$ Communications generally take place through Inmarsat LRIT, HF, or VHF. ${ }^{404}$

The right whale ship reporting system is the first to protect a single species without significantly increasing vessel safety, since most large vessel whale strikes have little impact on the vessels themselves. ${ }^{405}$

In 2004, NMFS requested comments on proposed regulations aiming to reduce the likelihood of right whale ship strike mortalities. ${ }^{406}$ The agency

395. See id. at 166 .

396. Id.

397. Id. at 167.

398. See Atlantic Whale Reporting System, supra note 201 (detailing rules for system); Mandatory Ship Reporting System for North Atlantic Right Whales, NATIONAL OCEANIC AND ATMOSPHERIC ASSOCIATION, http://www.nmfs.noaa.gov/pr/shipstrike/msr.htm (last updated Feb. 25, 2013, archived at http://perma.cc/B8LL-RMRJ); see generally 33 C.F.R. pt. 169 (implementing ship routing system rules into United States law).

399. Atlantic Whale Reporting System, supra note 201, ๆ2.

400. Atlantic Whale Reporting System, supra note 201, at Appendix 1. There is no traffic separation scheme for the southern reporting area. See Atlantic Whale Reporting System, supra note 201, at Appendix 2.

401. Atlantic Whale Reporting System, supra note 201, $₫ \uparrow \mid 3.2-3.3$.

402. Atlantic Whale Reporting System, supra note 201, $\$ 4.1$.

403. Atlantic Whale Reporting System, supra note 201, $\$ 4.4$.

404. Atlantic Whale Reporting System, supra note 201, $₫ 5$.

405. See Luster, supra note 394, at 166.

406. Advance Notice of Proposed Rulemaking (ANPR) for Right Whale Ship Strike 
noted that despite its efforts to notify mariners of right whale sightings and ship strikes, impose mandatory ship reporting systems, collaborate with the Coast Guard, and take other measures, right whales were still being killed as a result of collisions with vessels. ${ }^{407}$

In 2005, environmental groups submitted a petition to NMFS for emergency rulemaking. ${ }^{408}$ The petition included a request for a twelve-knot speed limit for all ships within twenty-five miles of all major East Coast ports during expected right whale high-use periods. ${ }^{409}$ NMFS denied the request. ${ }^{410}$ The environmental groups unsuccessfully sued the agency for denying emergency rulemaking and for other alleged violations of the Endangered Species Act regarding right whales. ${ }^{411}$ But in 2008, NMFS adopted a final rule limiting the speed of most vessels to ten knots in certain areas at particular times of the year when whales are expected to be present. ${ }^{412}$ NMFS has successfully enforced the required speed limits in a number of cases. ${ }^{413}$

In 2006, IMO approved a modification to an existing traffic separation scheme ${ }^{414}$ for the Boston/New York area in order to move large ships away from waters with high concentrations of whales and areas

Reduction, 69 Fed. Reg. 30857 (2004).

407. Id. at 30858 .

408. Petition for Initiation of Emergency Rulemaking To Prevent the Extinction of the North Atlantic Right Whale to the Secretary of Commerce, the Administrator of the National Oceanic and Atmospheric Administration, and the Assistant Administrator for Fisheries at NMFS (May 19, 2005), cited in Defenders of Wildlife v. Gutierrez, 532 F.3d 913, 916, 926928 (D.C. Cir. 2008) [hereinafter Emergency Rulemaking Petition].

409. Id. at 14 .

410. Id.; see 70 Fed.Reg. 56884 (2005).

411. Emergency Rulemaking Petition, supra note 408, at 28.

412. See 73 Fed. Reg. $§ 60173$ (2008); 50 C.F.R. $§ 224.105$ (2011) (outlining effective times of year and geographic boundaries). The rule applies to all vessels (except those operated by or under contract to Federal agencies) that are 65 feet or greater in overall length in certain locations, and at certain times of the year along the east coast of the U.S. Atlantic seaboard. Id.

413. In 2012, NOAA announced the resolution of three cases involving large commercial vessels that violated speed limits in the right whale habitats. Randy Boswell, Groups Call for Speed Limits in the Northwest Passage; Slowing Down Ships could Save Wildlife, CALGARY HERALD, Mar. 17, 2012, at A20, archived at http://perma.cc/YQX9-DNVE. The owner of a German cargo ship agreed to pay 16 separate fines totaling $\$ 92,000$ for repeated speeding violations off the Florida coast. Id. Two other ship owners agreed to pay their fines as well, and six more were still facing charges of breaking the 10-knot speed limit. Id. The ships had been clocked at up to 18 knots and were charged with $\$ 5,750$ tickets for each infraction. $I d$.

414. The traffic separation scheme was originally adopted to service Boston in 1973 and amended in 1983 to include a precautionary area and connect with the New York traffic scheme. See United States, Proposed Amendment of the Traffic Separation Scheme "In the Approach to Boston, Massachusetts" submitted to the International Maritime Organization, Sub-Committee on Safety of Navigation $\uparrow 2$, NAV 54/3/XX (Mar. 15, 2008), archived at http://perma.cc/AMR6-TNCB. 
frequently transited by smaller fishing boats. ${ }^{415}$ The lane shift added 3.75 nautical miles to the overall distance and ten to twenty-two minutes to each one-way trip. ${ }^{416}$

In 2009, IMO approved a voluntary seasonal area to be avoided off the northeastern coast for ships weighing 300 gross tons or more. ${ }^{417}$ The area to be avoided corresponds to the whales' feeding area. ${ }^{418}$ The restriction goes into effect each year between April and July, when the whales face the highest risk of ship strikes in this area. ${ }^{419}$ The same year, IMO approved a proposal narrowing traffic lanes servicing Boston in order to reduce the threat of vessel collisions with right whales and other whale species. ${ }^{420}$ Each lane is now 1.5 nautical miles wide. ${ }^{421}$

In 2012, NOAA developed an iPad and iPhone application that warns mariners when they enter areas of high risk of collision with the right whales. ${ }^{422}$ The free application also provides information about right whale management measures, including speed limits, areas to be avoided, and the latest data about right whale detections, all overlaid on NOAA digital charts. ${ }^{423}$ The application uses near real-time acoustic buoys that allow the locations of whale calls to be shown on a screen. ${ }^{424}$

Scientists estimate that the traffic control measures adopted for the North Atlantic have reduced the risk of collision by 60 to 80 percent. $^{425}$

415. See Press Release, NOAA, NOAA \& Coast Guard Help Shift Boston Ship Traffic Lane to Reduce Risk of Collisions with Whales (June 28, 2007), archived at http://perma.cc/6ER6-T8U8.

416. Id.

417. Press Release, NOAA, Changes in Vessel Operations May Reduce Risk of Endangered Whale Shipstrikes (May 26, 2009), archived at http://perma.cc/9YH4-TV6B.

418. Id.

419. Id.

420. $I d$.

421. Id. ("The width of the north-south portion of the lanes will narrow from a total of four miles to three miles.").

422. Press Release, NOAA, Stellwagen Bank National Marine Sanctuary, New iPad, iPhone app helps mariners avoid endangered right whales (Apr. 4, 2012), archived at http://perma.cc/LXN3-7DC8.

423. Id.

424. Id. (explaining that sound-detecting buoys detect right whale vocalizations within a five-mile radius and pass the signal via satellite to Cornell University's Bioacoustics Research Program where a technician confirms whether the sound corresponds to a right whale; if confirmed, Cornell triggers a message via AIS to the Whale Alert application, allowing the Whale Alert buoy icon to turn yellow on the map so that vessels can slow down and post a lookout to avoid collision).

425. See id. (the 2009 area to be avoided and revised traffic separation scheme were expected to reduce the relative risk of right whale ship strikes by about $74 \%$ during AprilJuly ( $63 \%$ from the area to be avoided and $11 \%$ from the narrowing of the Traffic Separation Scheme)); Cooper, supra note 48, at 6 (at a 2012 Nome workshop on arctic shipping, NOAA wildlife biologist Brad Hansen suggested that the rerouting of ships to areas with lower densities of right whales has resulted in an $80 \%$ drop in ship strikes); WWF PARS 


\subsection{Northern Canada-Ship Reporting System and Vessel Traffic Service}

Canada has implemented shipping rules that maximize its jurisdiction over Arctic waters; however, some have argued that the rules exceed the limits of international law. In 1970, Canada enacted the Arctic Waters Pollution Prevention Act to prevent pollution of its arctic marine environment. ${ }^{426}$ The Act established a 100-nautical mile shipping safety control zone where passage through Arctic Canadian waters could only be achieved through compliance with certain construction, navigational, and operations standards. ${ }^{427}$ In 2008 , Canada extended the zone to 200 nautical miles, the outer limit of its exclusive economic zone. ${ }^{428}$ While Canada has maintained that it has a right to regulate its internal waters, critics assert that the areas subject to the 2008 law are international straits, and that the law violates the regime for international straits established by UNCLOS. ${ }^{429}$

In 1977, Canada adopted a voluntary VTS, known as NORDREG, for the Canadian Arctic. ${ }^{430}$ Canada's 2001 Shipping Act ${ }^{431}$ established vessel traffic services (VTS) zones and allowed the Canadian Coast Guard to require vessel reporting and clearance. ${ }^{432}$ The Coast Guard did not act on this authority until 2010, when it issued regulations ${ }^{433}$ requiring large

COMMENTS, supra note 3, at comment 17 (citing Vanderlaan et al., Reducing the Risk of Lethal Encounters: Vessels and Right Whales in the Bay of Fundy and on the Scotian Shelf, 4 Endangered Species Research 283 (2008)) (modifications to the Bay of Fundy traffic separation scheme reduced the relative risk of collision with whales by up to 62 percent); see also REPORT OF THE JOINT IWC-ACCOBAMS WORKSHOP ON REDUCING RISK OF COLLISIONS BETWEen Vessels AND CETACEANS 14 (June 1, 2011), archived at http://perma.cc/CC6ZMMWZ (wherever practical, vessels should be separated from whales using measures such as re-routing or areas/times to be avoided).

426. Arctic Waters Pollution Prevention Act, R.S.C., 1985, c. A-12 (Can.); see also Chapter 5: Shipping in the Canadian Arctic, CANADIAN COAST GuARD, http://www.ccggcc.gc.ca/e0010979 (last updated June 24, 2013, archived at http://perma.cc/Y7G7-GXA4) (describing the Act).

427. See Arctic Waters Pollution Prevention Act, R.S.C., 1985, c. A-12 (Can.); Matthew Carnaghan \& Allison Goody, Political and Social Affairs Division of the Canadian Parliamentary Information and Research Service, Canadian Arctic SOVEREIGNTY (Jan. 26, 2006), archived at http://perma.cc/4R7Q-N4FL (detailing history of act).

428. Penny Becklumb, Industry, Infrastructure and Resources Division of the Canadian Parliamentary Information and Research Service, Legsilative Summary of Bill C-3: An Act to Amend the Arctic Waters Pollution Prevention Act (Dec. 12, 2008), archived at http://perma.cc/J4YL-RF9E.

429. See generally Ryan O'Leary, Protecting the Arctic Marine Environment: The Limits of Article 234 and the Need for Multilateral Approaches, 23 J. Env. L. \& Prac. 287 (2012).

430. AMSA REPORT, supra note 2, at 66.

431. Canada Shipping Act, 2001, S.C. 2001, c. 26 (Can.).

432. Id. $\S \S 126,136$.

433. Northern Canada Vessel Traffic Services Zone Regulations, SOR/2010-127 (Can.) [hereinafter NORDREG Regulations]. 
vessels ${ }^{434}$ to participate in a reporting system. ${ }^{435}$ A ship's initial report to the Coast Guard must include the vessel's name, last port of call, position, course, speed, destination, estimated time of arrival, intended route, draught, cargo, and number of people on board. ${ }^{436}$ An additional report must be provided if the vessel deviates from course; or if the vessel discovers another vessel in apparent difficulty, any obstruction to navigation, a malfunctioning aid to navigation, hazardous ice or weather conditions, or a pollutant in the water. ${ }^{437}$ Reports are provided via radio, facsimile, email, telex, or telephone. ${ }^{438}$

Canada may impose fines up to $\mathrm{C} \$ 100,000(\$ 90,440$ - as of April 1, 2014) or imprisonment for one year against ship-owners that violate the reporting regulations. ${ }^{439}$

IMO has not approved NORDREG, and several states have contested NORDREG's mandatory nature at sessions of the IMO's Maritime Safety Committee. ${ }^{440}$ Canada asserts that the mandatory reporting system is consistent with international law regarding ice-covered areas, ${ }^{441}$ and that the waters subject to the system are internal waters within Canada's exclusive

434. The regulations apply to vessels of 300 tons or more, vessels engaged in towing or pushing another vessel where their combined tonnage is 500 tons or more, and vessels carrying a pollutant or dangerous goods or which are towing or pushing a vessel carrying such materials. See id., at 3; Vessel Traffic Reporting Arctic Canada Traffic Zone (NORDREG), CANADIAN COAST GUARD (June 2013), http://www.ccggcc.gc.ca/eng/MCTS/Vtr_Arctic_Canada, archived at http://perma.cc/4HL8-9D6Z [hereinafter NORDREG].

435. See NORDREG Regulations, supra note 433, at 7-8; NORDREG, supra note 434. A vessel must send a report just before entering any one of Canada's northern shipping zones, just after entering a zone, daily at 1600 Coordinated Universal Time, upon arrival at a port within a zone, and when leaving the zone. $I d$. Vessels issuing information automatically with LRIT do not have to manually issue the 1600 report. NORDREG, supra note 434.

436. NORDREG Regulations, supra note 433, at 7-8.

437. NORDREG Regulations, supra note 433, at 9; NORDREG, supra note 434.

438. NORDREG, supra note 434.

439. Leo Ryan, Canada to Get Tough with Arctic Rules Offenders, LloYD's LisT (July 8, 2010), http://www.lloydslist.com/11/sector/regulation/article173180.ece, archived at http://perma.cc/KN59-KJ9Y.

440. Andreas Raspotnik, Positive Unilateralism - An Effective Strategy to Protect the Canadian Arctic Environment or a Subtle Approach to Establish Sovereignty?, THE ARCTIC Institute, Center FOR Circumpolar Studies (Dec. 23, 2011), http://www.thearcticinstitute.org/2011/12/92743-positive-unilateralism-effective.html, archived at http://perma.cc/F435-9EVJ. Nations and international entities contesting the designation include U.S., EU, Germany and Singapore. Id.

441. See NORDREG, supra note 434. UNCLOS Art. 234 allows coastal states to adopt regulations for "the prevention, reduction and control of marine pollution from vessels in ice-covered areas within the limits of the exclusive economic zone, where particularly severe climatic conditions and the presence of ice covering such areas for most of the year create obstructions or exceptional hazards to navigation, and pollution of the marine environment could cause major harm to or irreversible disturbance of the ecological balance." UNCLOS, supra note 65. 
jurisdiction (i.e., not international straits). ${ }^{442}$

\subsection{Puget Sound/Juan de Fuca Region-Vessel Traffic Service}

The Strait of Juan de Fuca, an eighty nautical mile long, narrow body of water between Washington State and Canada's Vancouver Island, serves as the primary connection between the Puget Sound and the Pacific Ocean. ${ }^{433}$ It is approximately twelve nautical miles wide where it meets the Pacific Ocean and widens to sixteen nautical miles. ${ }^{444}$ The Puget Sound, a bay with numerous channels and branches, extends approximately seventy nautical miles from the eastern end of the Strait of Juan de Fuca to the city of Olympia, Washington. ${ }^{445}$ While navigation is relatively simple in good weather, the area is subject to strong winds and storms in the winter, and heavy fog from July to October. ${ }^{446}$

Vessel traffic in the Puget Sound/Juan de Fuca region is managed jointly by the Canadian and United States Coast Guards through a Vessel Traffic Service, a traffic separation scheme, and surveillance systems including radar, AIS, and closed circuit television. ${ }^{447}$

The United States and Canadian Coast Guards adopted an Agreement for a Cooperative Vessel Traffic Management System for the San Juan de Fuca Region on the Pacific Coast in $1979 .{ }^{448}$ The purpose of the VTS is to provide for the safe and efficient movement of vessel traffic while minimizing the risk of pollution by preventing collisions and groundings. ${ }^{449}$

IMO approved the original Traffic Separation Schemes (TSS) associated with the VTS in 1981, and the routes have been modified several times since then to improve navigation. ${ }^{450}$ The traffic separation scheme

442. Ryan, supra note 439, $§ 166$.

443. Richard Gilmore \& Ronald E. Englebretson, Puget Sound Area Heavy Weather Port Guide, ch. 1 (1996), archived at http://perma.cc/5598-72DT.

444. Id.

445. Id.

446. 7 NOAA Office of Coast Survey, U.S. Coast Pilot 481-485 (44th ed., 2012), archived at http://perma.cc/HNZ-27S8 (Chapter 12: Strait of Juan De Fuca and Georgia, Washington).

447. U.S. Coast Guard, Vessel Traffic Service Puget Sound Manual iv (2007), archived at http://perma.cc/X8TT-KGD8 [hereinafter VTSPS MANUAL].

448. Exchange of Notes Constituting an Agreement on Vessel Traffic Management of the Juan de Fuca Region, 1221 U.N.T.S. 67 (Dec. 19, 1979).

449. USCG: Purpose and Objective-Canada/U.S. Co-Cooperative Vessel Traffic System Agreement, U.S. COAST GUARD, http://www.uscg.mil/d13/cvts/purposeandobjective.asp (last updated July 2, 2013, archived at http://perma.cc/78DE-5E4F) (describing purpose and objective of cooperative vessel traffic system for the Strait of Juan de Fuca region).

450. See Traffic Separation Schemes: In the Strait of Juan de Fuca and Its Approaches; in Puget Sound and Its Approaches; and in Haro Strait, Boundary Pass, and the Strait of Georgia, 75 Fed. Reg. 70818, 70819 (Nov. 19, 2010) (describing the history of the traffic separation scheme), citing IMO Circular COLREG.2/Circ.55 dated Dec. 15, 2004 
provides for a western approach and lanes, a southwestern approach, northern lanes, eastern lanes, and a precautionary area. ${ }^{451}$

Three Vessel Traffic Centers manage traffic for the VTS. Puget Sound Vessel Traffic Service, which has been in place since 1972, is operated by the U.S. Coast Guard out of Seattle. ${ }^{452}$ The other two centers have been operated by the Canadian Coast Guard since 1973. Toffino Traffic, located at Vancouver Island, manages vessels entering the Strait of Juan de Fuca from about forty miles out. ${ }^{453}$ Seattle Traffic manages vessel traffic in both the Canadian and US waters of the Strait of Juan de Fuca and traffic headed to US ports. ${ }^{454}$ Victoria Traffic manages vessels in both the Canadian and US waters bound for Canadian ports as they proceed north toward Victoria. ${ }^{455}$ Vessels change their radio frequency to communicate with the appropriate center. ${ }^{456}$ The three Vessel Traffic Centers communicate via a computer link and dedicated telephone lines to advise each other of vessels passing between their respective zones. ${ }^{457}$

Vessels subject to reporting requirements must provide an initial report, a position report at certain points in the system, and a final report. ${ }^{458}$ The initial report indicates the vessel name, type, position, destination and estimated time of arrival, anticipated speed, intended route, time and point of entry into the Seattle Traffic Area, and any dangerous cargo on board, ${ }^{459}$ while the final report indicates the vessel name and position when leaving the system. ${ }^{460}$ Vessels must also report any deviations from the original schedule $^{461}$ and any accidents or dangerous situations, including pollution incidents and adverse weather conditions. ${ }^{462}$

Vessels are required to monitor radio frequencies applicable to the VTS including power-driven vessels of twenty meters or more in length; vessels of 100 gross tons or more carrying one or more passengers for hire;

(approving modifications) and IMO Circular COLREG.2/Circ.57 dated May 26, 2006 (approving modifications). The United States cooperated with Canada in conducting Port Access Route Studies and in preparing joint proposals for IMO approval. Id.

451. 33 C.F.R. $\$ \S 167.1300,167.1310$ (2010).

452. Cooperative Vessel Traffic Service, U.S. COAST GUARD, http://www.uscg.mil/d13/dep/news/cooperative_vessel_traffic_servi.asp (last updated Mar. 31, 2013, archived at http://perma.cc/RX4Z-LM2Q) [hereinafter CVTS Website].

453. Id.

454. Id.; USCG: Purpose and Objective-Canada/U.S. Co-Cooperative Vessel Traffic System Agreement, U.S. COAST GUARD, http://www.uscg.mil/d13/cvts/purposeandobjective.asp (last updated July 2, 2013, archived at http://perma.cc/9KRE-DM66).

455. CVTS Website, supra note 452.

456. CVTS Website, supra note 452.

457. VTSPS MANUAL, supra note 447.

458. VTSPS MANUAL, supra note 447, at 1-4.

459. VTSPS MANUAL, supra note 447, at 1-4.

460. VTSPS MANUAL, supra note 447, at 1-4.

461. VTSPS MANUAL, supra note 447, at 1-4.

462. VTSPS MANUAL, supra note 447 , at 1-5, 1-8. 
and dredges or floating plants. ${ }^{463}$ Power-driven vessels of forty meters or more in length; commercial vessels of eight meters or more in length, while engaged in towing; and vessels certified to carry fifty or more passengers for hire, when engaged in trade, are required to make voice reports to the appropriate Traffic Center. ${ }^{464}$ All vessels must comply with the Convention for the International Regulations for Preventing Collisions at Sea (COLGREGs) provisions applicable to traffic separations schemes as well as any directive issued by a Vessel Traffic Center. ${ }^{465}$ Approximately thirty times each year, vessel traffic service operators must intervene to prevent collisions. ${ }^{466}$ They give direct navigational instructions to vessels in these close-call situations. ${ }^{467}$

\subsection{Alaska Eskimo Whaling Commission Conflict Avoidance Agreement- Ship Reporting System and Routing System}

Each year, the Alaska Eskimo Whaling Commission (AEWC) enters into a Conflict Avoidance Agreement with oil and gas industry companies whose operations and vessel traffic in the Beaufort and Chukchi Seas may interfere with subsistence hunting of the bowhead whale. ${ }^{468}$ The Chukchi Sea is defined to include "all waters off the western and northern coasts of Alaska from Cape Prince of Wales to Point Barrow." "469 Cape Prince of Wales is on the western coast of Alaska directly adjacent to the Bering Strait. $^{470}$

The Agreement establishes equipment and procedures for communications between whalers and industry participants; avoidance measures to be taken in the vicinity of subsistence hunting; emergency measures; and dispute resolution procedures. ${ }^{471}$ The Agreement also lists contact information for representatives from each industry vessel and village as well as vessels that will be used in industry operations. ${ }^{472}$

All participants are required to monitor the same VHF radio

\footnotetext{
463. CVTS Website, supra note 452.

464. CVTS Website, supra note 452.

465. VTSPS MANUAL, supra note 447, at 1-2.

466. CVTS Website, supra note 452.

467. CVTS Website, supra note 452.

468. E.g., CAA, supra note 26. The agreement operates during "Open Water Season"the period of the year when ice conditions permit navigation or oil and gas operations to occur in the Beaufort Sea or Chukchi Sea. CAA, supra note 26, §§ 103(a)(12), 104(b)(2).

469. CAA, supra note $26, \S 103(\mathrm{~b})(2)$.

470. Cape Prince of Wales - Alaska, SATELliteVIEWS.NET, http://www.satelliteviews.net/cgi-bin/g.cgi?fid=1399909\&state=AK\&ftype=cape (last visited April 4, 2014, archived at http://perma.cc/W6FG-BCAM).

471. CAA, supra note 26, § 102 (Purpose).

472. CAA, supra note $26, \S \S 206,401$ (a).
} 
channel ${ }^{473}$ and report by voice call to one of nine communication centers established under the Agreement and funded by the industry participants. ${ }^{474}$ Additional VHF channels are assigned for communications within each village area and for industry vessels to communicate with communication centers. ${ }^{475}$ Satellite phones serve as a backup to VHF. ${ }^{476}$

Every six hours, an industry vessel within the reporting area ${ }^{477}$ must report to the closest communication center $^{478}$ the vessel's name, operator, and owner; the project the vessel is working on; the vessel's location, speed, and direction; and plans for vessel movement between the time of the call and the time of the next call. ${ }^{479}$ Vessels must also report any unsafe or unanticipated ice conditions; and any significant change in plans, such as an unannounced start-up of operations or significant deviations from an announced course, so that the communication center can notify all whalers of the changes. ${ }^{480}$

Each industry participant must hire a Marine Mammal Observer to work on board of certain types of vessels. ${ }^{481}$ The observer is responsible for keeping a lookout for bowhead whales and/or other marine mammals in the vicinity of the vessel, to assist the vessel captain in avoiding harm to these animals. ${ }^{482}$ When the vessel is in the vicinity of a whaling area, the observer is responsible for communicating with communication centers and with whalers by VHF radio. ${ }^{483}$

Whaling captains report to a communication center when they launch

473. CAA, supra note $26, \S 202(\mathrm{c})(1)$.

474. CAA, supra note $26, \S 203(\mathrm{~b})$. Industry participants also fund the whalers' VHF equipment. CAA, supra note $26, \S 205$ (a).

475. CAA, supra note $26, \S 205(\mathrm{a}-\mathrm{b})$.

476. CAA, supra note $26, \S 205(\mathrm{a})(6)$.

477. The reporting area for most vessels starts once they pass Cape Prince of Whales and enter the Chukchi Sea. See CAA, supra note 26, § 104(b)(2) (indicating the general scope as the Beaufort and Chukchi Seas); CAA, supra note 26, § 103(b) (defining the Chukchi Sea as the "all waters off the western and northern coasts of Alaska from Cape Prince of Wales to Point Barrow"). The 2012 Agreement added a new Section 505, which requires vessels to report if they are unable to reach a point south of 59 degrees North latitude by November 15 due to weather or ice. The 2012 Agreement also added a new Section 602, requiring vessels engaged exclusively in geophysical (seismic) operations to report when forty miles off the coast of Alaska. Email from Earl Comstock, AEWC Counsel, to author (Oct. 2, 2012).

478. The Agreement refers to the "appropriate" communication center, which is understood to mean the closest communication center. Email from Earl Comstock, AEWC Counsel, to author (Oct. 2, 2012).

479. CAA, supra note 26, §§ 202(a)(1), 602(a)(1).

480. CAA, supra note $26, \S \S 202(\mathrm{a})(2), 602(\mathrm{a})(2)$.

481. CAA, supra note $26, \S 201$ (a). These vessels include most vessels used for seismic operations, ice-breakers, and the lead vessel in a group of barge or transit vessels. See CAA, supra note 26, § 103(a)(14).

482. CAA, supra note $26, \S 201(\mathrm{~b})(4)$.

483. CAA, supra note $26, \S \S 201(\mathrm{~b})(3-7), 202(\mathrm{c})(3)$. 
their boats from shore and again when they return to shore. ${ }^{484}$ They report their whaling camp location, boat location, general direction of travel, plans for the following day, and any industry vessels not observing the Agreement's provisions on avoiding conflicts. ${ }^{485}$

If industry vessels and whaling boats are in the same area at the same time, ${ }^{486}$ the communication center plots the information received on maps and alerts industry vessels of any possible conflicts. ${ }^{487}$ If whaling boats and vessels fail to report on time, the communication center attempts to contact the boat or vessel to obtain the required information. ${ }^{488}$

Vessels are required to avoid areas of active or anticipated whaling activity. ${ }^{489}$ Vessels are advised (though not required) to stay at least five miles offshore to avoid whaling areas. ${ }^{490}$ If weather and ice conditions permit, vessels must transit on the eastern side of St. Lawrence Island and no closer than ten miles from the island's shore. ${ }^{491}$

The speed limit for vessels "in the proximity of feeding whales or whale aggregations" is ten knots. ${ }^{492}$

If a vessel inadvertently approaches within a mile of observed bowhead whales, it must take additional precautions, which may include

reducing vessel speed to less than five knots within 900 feet of the whale(s);

steering around the whale(s) if possible;

operating the vessel in such a way as to avoid separating a group of whales;

operating the vessel to avoid causing a whale to make multiple changes in direction; and

checking the waters immediately adjacent to the vessel(s)

to ensure that no whales will be injured when the propellers are engaged. ${ }^{493}$

The Agreement goes beyond communications between vessels at sea.

484. CAA, supra note 26, § 202(b).

485. CAA, supra note $26, \S 202$ (b).

486. In an effort to adhere to the Conflict Avoidance Agreement, oil and gas operators generally time operations to avoid interfering with the active whaling periods. For instance, during the fall 2012 whaling season, Shell Oil Co. did not start its operations near the villages of Kaktovik and Nuiqsut until whalers in these villages completed their hunts. Email from Johnny Aiken, AEWC Director, to author (Nov. 13, 2012).

487. CAA, supra note $26, \S 203(\mathrm{~d})(4-5)$.

488. CAA, supra note $26, \S 203(\mathrm{~d})(3)$.

489. CAA, supra note 26, §§ 202(c), 501(a).

490. CAA, supra note $26, \S \S 302(\mathrm{c}), 501(\mathrm{a})$.

491. CAA, supra note $26, \S 505$.

492. CAA, supra note 26, $\S \S 302(d), 501(\mathrm{c})$.

493. CAA, supra note 26, §§ 302(e), 501(d). 
Prior to the open water season (when operations and shipping take place), industry participants must meet with subsistence hunters to discuss the timing and location of planned activities. ${ }^{494}$ Participants also meet after the season to review results of the operations and discuss any concerns. ${ }^{495}$ Further, industry participants must provide advance notice regarding geophysical equipment sound signature tests and agree with $\mathrm{AEWC}$ on the location of testing. ${ }^{496}$ Each industry participant must implement a monitoring plan to collect data on the potential effects of its oil and gas operations on fall migrating bowhead whales. ${ }^{497}$ Geophysical activity is prohibited at certain times and locations where whales are expected to migrate. ${ }^{498}$ Waste discharge is prohibited in certain areas. ${ }^{499}$

In the event of an emergency, vessels are supposed to notify a communication center, which, in turn, is supposed to notify the nearest vessels and search and rescue authorities. ${ }^{500}$

\section{RECOMMENDATIONS FOR BERING SEA COMMUNICATIONS SYSTEM}

\subsection{Factors to Consider}

There are environmental, social, safety, economic, legal, and other factors to consider in designing and implementing a communications system for the Bering Strait Region.

From the perspective of those concerned with maintaining a healthy, resilient Arctic ecosystem, marine wildlife, and coastal communities, the degree to which a system can protect bowhead whales and other species is a primary concern. The system should be designed to avoid collisions with whales, prevent pollution, and ensure rapid response to any pollution incident. Since subsistence hunters depend on marine mammals for their nutritional needs and way of life, human welfare is closely linked to environmental concerns. To address these concerns, the adopted system should provide for protected areas corresponding to whale habitat and subsistence areas. Vessel speed should be controlled where whales and other marine mammals are present.

Navigational safety is another important concern for all stakeholders. Navigational safety avoids the risk of collisions and accidents that could

494. CAA, supra note $26, \S 108(\mathrm{c})$.

495. CAA, supra note $26, \S 108(\mathrm{a}-\mathrm{b})$.

496. CAA, supra note $26, \S 402$ (b).

497. CAA, supra note $26, \S 403$.

498. CAA, supra note 26, § 502 (providing geographical descriptions and dates pertaining to activity prohibitions).

499. CAA, supra note $26, \S 503(\mathrm{a})$.

500. CAA, supra note $26, \S 107(\mathrm{a})$. 
harm mariners as well as the environment. Any system will have to account for the unique navigational hazards associated with the region and ensure that vessels are able to respond to changing weather and ice conditions. The system will also have to account for the region's remote location and lack of infrastructure.

The ratio of costs to benefits will significantly influence whatever decision the U.S. Coast Guard reaches through its Port Access Route Study. ${ }^{501}$ Relative to other parts of the United States, operational costs in the Bering Strait Region are likely to be high. The Coast Guard may be unwilling to invest in a new control center in the region unless and until the traffic is comparable to other areas. ${ }^{502}$ While the traffic is rising, one day of traffic in the Port of San Francisco is currently equal to a year of traffic in the Bering Strait. ${ }^{503}$ If the Coast Guard is not willing to establish a permanent presence in the Bering Strait Region, it will be difficult to implement a vessel traffic service or ship reporting system. The system would have to rely on routing measures, aids to navigation, and/or automatic tracking measures that could be monitored from afar. Particularly if the Coast Guard does not establish any communication centers in the region, it may make sense to coordinate with and build on the existing system used by the Alaska Eskimo Whaling Commission.

International law and the interests of other countries will limit the ability of the United States to impose unilateral requirements on vessels in the Bering Strait Region. The United States would have difficulty asserting the right to regulation under UNCLOS Article 234 for ice-covered seas, since it has not ratified the convention. Even if the United States does ratify UNCLOS, its justification for unilateral regulations under Article 234 would be weaker than Canada's argument for regulating its Arctic waters. First, there is significantly less ice in the Bering Strait Region than in Canada's Arctic waters. Second, the Bering Strait Region is not entirely under US jurisdiction-much of it is in the Russian Exclusive Economic Zone. As the only connection between the Pacific and Arctic Oceans for thousands of vessels transiting through the area, the Bering Strait is likely to be considered an international strait subject to the right of transit passage under Article 38 of UNCLOS. If this is the case, the United States probably

501. See Bering Strait PARS, supra note 3, at 68 (asking for comments on which measures are most cost-effective).

502. See Alex DeMarban, As Arctic Shipping Grows, Native Hunters Aim to Protect Marine Mammals, AlaskA DisPATch (Mar 14, 2012), http://www.alaskadispatch.com/article/arctic-shipping-grows-native-hunters-aim-protectmarine-mammals?page=full, archived at http://perma.cc/ZV77-VFPS (referring to comments made by U.S. Coast Guard Capt. Adam Shaw that Native hunters should not expect a navigation center on Little Diomede soon).

503. See id. 
could not deny passage to non-compliant vessels, ${ }^{504}$ although it could attempt to coerce compliance with threats of fines and sanctions. Finally, it is still not clear whether Canada's assertion of jurisdiction over Arctic waters will be allowed to stand under international law.

The Bering Strait's status as international does not mean that the United States is without any power. It can cooperate with Russia to submit a proposal to IMO for a ship reporting or routing system, just as Australia and Papua New Guinea did for the Torres Strait. In connection with either of these systems, the United States could cooperate with Russia to implement a vessel traffic service, similar to that implemented by the United States and Canada for the Juan de Fuca region. Regardless of what system the United States decides to implement, Russian participation will be essential for obtaining IMO approval and for ensuring that marine mammals will be protected throughout the entire region. ${ }^{505}$

There are likely to be competing political concerns that pit the right of navigation against environmental protection and other interests. In the past, the United States has championed the right of unimpeded navigation and opposed efforts by Canada and others to assert control over navigation. ${ }^{506}$ On the other hand, the United States initiated a one-of-a-kind ship reporting system for the primary purpose of protecting North Atlantic right whales. ${ }^{507}$

504. See The ICJ Reports, Corfu Channel Case, Judgment of April 9, 1949 (1949) (concluding that an international strait "should be considered as belonging to the class of international highways through which passage cannot be prohibited by a coastal State in time of peace"); Restatement (Third) of Foreign Relations Law $\S 513$ cmt. j (1987) (a coastal state may not suspend transit passage through an international strait).

505. See DeMarban, supra note 502 (referring to comments made by U.S. Coast Guard Capt. Adam Shaw suggesting that without Russian participation, IMO likely will reject any scheme for the Bering Strait as insufficient). According to Coast Guard Cmdr. James Houck, as of March 2012, the Coast Guard was having difficulty finding someone to work with in the Russian Ministry of Transport. DeMarban, supra note 502.

506. Bering Strait PARS, supra note 3 , at 68 , (emphasizing that " $[\mathrm{t}]$ he designation of [traffic separation schemes] recognizes the paramount right of navigation over all other uses in the designated areas.") (alterations added); see also Press Release, U.S. Dep't of State, U.S. Opposes Unilateral Extension by Canada of High Seas Jurisdiction, (Apr. 15, 1970), cited in J.A. Beesley \& C.B. Bourne, Canadian Practice in International Law During 1970 as Reflected Mainly in Public Correspondence and Statements of the Department of External Affairs, 9 CAN. Y.B. INT'L L. 276, 287-88 (1971); Jason M. Krajewski, Out of Sight, Out of Mind? A Case for Long Range Identification and Tracking of Vessels on the High Sea, 56 Naval L. Rev. 219 (2008), citing The United States Naval War College, Annotated SuPplEMENT TO THE COMMANDER'S HANDBOOK ON THE LAW OF NAVAl OPERATIONS $\boldsymbol{q} \mid 2-32$ (1997) (the Navy maintains the U.S. right to freedom of navigation by making diplomatic assertions of customary international law rights and backing up those assertions through freedom of navigation operations).

507. The United States also decided to pursue a PSSA around its Pacific islands despite opposition from the U.S. Department of Defense. See Raul Pedrozo, Is it Time for the United States to Join the Law of the Sea Convention?, 41 J. MARITIME L. \& CoMM. 151, 160 (2010) (Department of Defense objected strenuously on national security grounds to President 
If the United States seeks greater control over what seems to be an international strait for purposes of environmental protection, this may weaken its ability to object to other coastal states seeking greater control.

Vessel owners and those that hold mineral rights in the region or north of it may oppose any system that appears to add an additional regulatory burden. That said, oil and gas operators may support a system that coordinates with the existing AEWC Conflict Avoidance Agreement, since they are already voluntarily complying with the Agreement's reporting requirements.

\subsection{Potential Regulatory Tools}

Most ship regulatory systems make use of multiple tools, ranging from ship reporting requirements to traffic separation schemes. All of these measures could be useful in the Bering Strait Region. Which one(s) will be implemented likely depends most on cost and political will. Regardless of what measures are implemented, the input of Bering Strait Region stakeholders should be sought. These stakeholders may benefit from the increased development opportunities associated with ship traffic, but have much to lose if ship pollution and accidents damage their subsistence resources. ${ }^{508}$

\subsubsection{Ship Reporting System}

It seems unlikely that the Coast Guard would be willing to implement a full ship reporting system similar to those adopted by IMO in other areas. Particularly if the Coast Guard does not plan to invest in vessel communication centers in the area, it should consider working with NOAA and AEWC to expand the existing system operating through the Conflict Avoidance Agreement. ${ }^{509}$ The Coast Guard could consider training those who currently operate the AEWC Communication Centers on Coast Guard

Bush's 2009 marine monument proclamations and to NOAA's proposal to the International Maritime Organization to designate a Pacific Particularly Sensitive Sea Area).

508. The Institute of the North has been awarded a National Park Service grant to create a Bering Strait Messengers Network, which aims to increase communication between communities in the region with local, state, and federal government bodies and Russian communities. See Diana Haecker, Institute of the North Proposes Bering Strait Communications Network, THE Nome NugGet, (Jan. 13, 2013) at 4. This network may help channel local stakeholder voices and could increase the communications infrastructure in the area.

509. Email from Earl Comstock, AEWC Counsel (Oct. 2, 2012) (AEWC would likely be open to discussing expansion of its system to include all vessels and Coast Guard participation, particularly if the expanded system would lead to greater Coast Guard search and rescue assistance. If the system is expanded, AEWC would encourage employing local people at communication centers to assist in communications with Iñupiaq-speaking whaling crews.). 
rules, and having Coast Guard personnel temporarily stationed at these centers during ice-free periods when significant traffic is expected. The AEWC Communication Centers currently operating within the Bering Strait Region include those in Point Lay, Point Hope, Kivalina, Wales, and Gambell/Savoonga. In most situations, the centers operate out of modest buildings (such as the Point Lay Whaling Captains' Association building) that will likely need additional communications equipment and space to accommodate Coast Guard personnel.

Alternatively, the United States could choose to invest in one or more new communication centers in the Bering Strait Region and require ships to report to this center at certain points. While it is possible that the communication center could be implemented outside of the region (at the Coast Guard's station in Dutch Harbor, for example), this distance would limit the means of communication. AIS would not work unless monitored by Internet based on actual receivers in the area. Also, if the Coast Guard operates from a distant center, it will not be able to provide timely aid to vessels and may have greater difficulty ensuring compliance with reporting requirements. If the United States chooses to implement a system that is not coordinated with the existing AEWC system, then it should consider entering into an agreement with AEWC and/or other local representatives to share real-time information pertinent to subsistence hunters. It should also consider employing people who have worked at AEWC Communication Centers or are from the region, as these people would have a better understanding of the hazards mariners are likely to face and the barriers to communication.

In order to make a ship reporting system mandatory, the United States would have to cooperate with Russia and submit a joint proposal to IMO. ${ }^{510}$ If the United States is unable to obtain Russia's cooperation or IMO's approval, it should consider having a voluntary reporting system.

Consideration should also be given to which kind of vessels would participate in the system. Participation should be broad enough to include ships with a potential for causing pollution or collision, but small vessels used for subsistence hunting and fishing should be exempt from the more expensive and time-consuming requirements.

Appendix 2 contains an outline for a simple IMO-ship reporting system, based on IMO-approved reporting systems contained in Ships' Routeing (2010 edition). The footnotes in the outline explain how Conflict Avoidance Agreement reporting requirements could be integrated into the system. 


\subsubsection{Ship Routing System}

A routing system could be established to avoid the most environmentally sensitive areas and subsistence areas in the region. This could be accomplished with relatively little investment through a voluntary system that is not patrolled. With greater investment, a mandatory system could be established along with a vessel traffic service and patrol to ensure that vessels are following the routing measures. Routing measures could include a mandatory or voluntary traffic separation scheme and Areas to be Avoided.

Depending on the volume of the traffic, multiple lanes may be required to separate deep draft vessels from shallower boats, which could probably be routed along lanes that are closer to the shore. Special lanes and/or or crossing points could be established for local fishing and whaling boats. In addition to traffic lanes, there could be waiting areas to the north and south of the strait for vessels to safely anchor in the event they are not ready to pass through the strait or need shelter from a storm.

To integrate routing requirements from the Conflict Avoidance Agreement, vessels in transit could be required to stay at least five miles offshore. ${ }^{511}$ Vessels could also be required to transit on the eastern side of St. Lawrence Island, no closer than ten miles from the island's shore. ${ }^{512}$

Speed restrictions could be required for areas where bowhead whales or other animals are likely to be present. Under the Conflict Avoidance Agreement, the speed limit for vessels "in the proximity of feeding whales or whale aggregations" is ten knots. ${ }^{513}$ If the United States adopted speed restrictions of ten knots in these areas, the risk of bowhead whale mortalities from collisions would be significantly reduced. ${ }^{514}$

511. CAA, supra note $26, \S \S 301(\mathrm{c})(2-3), 501(\mathrm{a})(2-3)$.

512. CAA, supra note $26, \S 505$.

513. CAA, supra note 26, §§ 302(d), 501(c).

514. See MMC PARS COMMENTS, supra note 7, at 2, 5 (recommending that a vessel speed limit of 10 knots be considered if vessel traffic is likely to overlap with peak bowhead migration); REPORT OF THE JOINT IWC-ACCOBAMS WORKSHOP ON REDUCING RISK OF Collisions Between Vessels AND Cetaceans 24 (June 1, 2011), archived at http://perma.cc/9WS7-KV45 (rerouting should be the first option considered, but where separating vessels from whales is not practical, measures to reduce speed should be considered); Vanderlaan, A. S. M. \& C. M. Taggart, Vessel Collisions with Whales: the Probability of Lethal Injury Based on Vessel Speed, 23(1) MARINE Mammal SCIENCE 144 (2007), archived at http://perma.cc/8TM8-MNV9 (noting that the probability of a lethal injury from a strike drops below $50 \%$ at 11.8 knots, whereas the probability approaches $100 \%$ at speeds above 15 knots); Randy Boswell, Groups Call for Speed Limits in the Northwest Passage; Slowing Down Ships Could Save Wildlife, Calgary Herald, A20, Mar. 17, 2012, archived at http://perma.cc/N3Y2-W9RF (citing NOAA statement that the likelihood of a whale fatality due to ship strike increases from around $45 \%$ to $75 \%$ when vessel speed increases from 10 to 14 knots; chance of death at 17 knots is $90 \%$ ); Regulations Governing the Approach to Humpback Whales in Alaska, 66 Fed. Reg. 29,502, 29,503 (May 
As with a ship reporting area, the United States would not be able to establish an effective mandatory routing system without the involvement of Russia and IMO ${ }^{515}$ though it could establish a voluntary system.

\subsubsection{Vessel Traffic Service}

The United States would have difficulty implementing a stand-alone VTS for the Bering Strait, since VTSs are only allowed in territorial waters and the Bering Strait is probably an international strait. A VTS could be implemented in connection with an IMO-approved ship reporting and/or routing system if justified by the volume of traffic in the region. ${ }^{516}$ Currently, the volume of traffic in the Bering Strait is low compared to other international straits. Still, a VTS could be justified by the risk of collisions between ships and marine mammals due to the narrowness of the strait and the likelihood that certain species of marine mammals will be present at specific times of the year.

As would be the case for a ship reporting system, the United States would have to coordinate the location of the VTS center(s) with Russia. There could be a single VTS center in the United States similar to the control center in Queensland for the Torres Strait. Or there could be multiple VTS centers, with at least one on each side, as is the case for the San Juan de Fuca region.

Alternatively, the United States could pursue a voluntary VTS for the Bering Strait or a mandatory VTS for areas outside of the strait itself that are part of the US territorial sea and experience significant volumes of traffic.

\subsubsection{Aids to Navigation}

Currently, there are only a handful of Coast Guard-maintained navigational aids and NOAA-maintained buoys in the vicinity the Bering Strait. ${ }^{517}$ Particularly if the United States decides not to have a reporting system or vessel traffic service through which it can warn mariners of dangers, additional navigational aids and buoys should be established in the area. The United States should also consider installing buoys capable of detecting bowhead whale calls, although this would require a significant

31, 2001) (citing David W. Laist, et al., Collisions between Ships and Whales, 17(1) MARINE MAMMAL SCIENCE 35-75 (Jan. 2001) ("[A] study of worldwide occurrences of whales struck by ships indicated that most lethal or severe injuries to whales struck by vessels occurs by ships traveling 14 knots (kts) or faster")).

515. See supra Section 3.2 (Ship Routing System).

516. See SOLAS, supra note 96, Reg. V/12.2 (2002) (parties to SOLAS can arrange to establish a VTS where, in their opinion, the volume of traffic or the degree of risk justifies such services). The Torres Strait VTS (REEFVTS) is an example of a VTS that was implemented in connection with an IMO-approved ship reporting system.

517. AMSA REPORT, supra note 2, at 109; see also Appendix 3, infra. 
investment and it is not clear how well this type of buoy would tolerate the conditions in the Bering Strait Region. ${ }^{518}$

\subsubsection{Tracking Systems}

LRIT and/or AIS, both of which are already required for most large vessels by SOLAS and US law, could be integrated into a ship reporting system, although AIS has a limited horizontal range. Both systems could be supplemented with VHF voice communications.

\subsubsection{Designation of Areas with Special Regulations}

Areas subject to protective regulations could be designated through a variety of means. Under US law, the Coast Guard could designate Areas to be Avoided or Precautionary Areas within US waters. ${ }^{519}$ NMFS could designate critical habitat for the bowhead whale within the US 200-mile Exclusive Economic Zone, ${ }^{520}$ although the likelihood of this seems slim. ${ }^{521}$

518. See Kirk Lombardy, United States Coast Guard Assists NOAA in Deploying Great Lakes NOAA Weather Buoy, NOAA (Nov. 2, 2013), www.erh.noaa.gov/cle/office/localinterest/bristol1.htm, archived at http://perma.cc/U24EGF4V (stating that "during the winter months, smaller and likely less expensive buoys" are used in Lake Erie "due to the ravaging effects of ice that develops on the lake" and that "larger buoys would likely be lost to the ice if left out on the lake during the winter."); National Geospatial-Intelligence Agency, Short Range Aids to Navigation, in 72 AMERICAN Practical Navigator 5, archived at http://perma.cc/SQP3-AEKY (buoys are subject to a variety of hazards including severe weather, collision, mooring casualties, and electrical failure); but see Weather Buoys, HurRiCANES, SCIENCE AND SOCIETY, www.hurricanescience.org/science/observation/ships/weatherbuoys/ (last visited Feb. 15, 2014, archived at http://perma.cc/7B3J-HET2) (describing buoys located from the Bering Sea to the South Pacific, stating that buoys can face rough weather and are anchored using anything from chains in shallow waters to heavy-duty, polypropylene rope in deeper waters).

519. See 33 U.S.C. $§ 1223$ (2006) (authority for implementing vessel routing measures); 33 C.F.R. Part 167 (1983) (defining Areas to be Avoided and Precautionary Areas; describing where these areas exist in U.S. waters).

520. Although the bowhead whale has been listed as an endangered species since 1970, critical habitat has not been designated. See Endangered Species Conservation Act of 1969, 35 Fed. Reg. 8495 (June 2, 1970) (designating bowhead as endangered species); Final Determination on a Petition to Designate Critical Habitat for the Bering Sea Stock of Bowhead Whales, 67 Fed. Reg. 55,767 (Aug. 30, 2002) (denying petition to designate critical habitat); NMFS, Notice of determination issuance of an incidental take authorization, 75 Fed. Reg. 49,709, 49,756 (Aug. 13, 2010) ("There is no critical habitat designated in the U.S. Arctic for the bowhead whale and humpback whale.").

521. In 2002, NMFS rejected a petition to designate critical habitat for bowhead whales based on its determination that the designation of critical habitat for species listed prior to 1978 is discretionary. The decline and reason for listing the species was overexploitation by commercial whaling, and habitat issues were not a factor in the decline. Habitat degradation was not shown to have a negative impact on the increasing population. The population was increasing, and existing laws and practices adequately protected the species and its habitat. 
Even if NMFS does designate critical habitat, it may decide not to require any restrictions on barge and vessel movement beyond the requirement for federal agencies to consult with NMFS under ESA Section $7 .^{522}$ This was the case for NMFS's critical habitat designation for Cook Inlet beluga whales in $2011 .^{523}$

A stronger option would be for the United States to work with Russia on an IMO proposal that incorporates areas subject to special regulation. This could be accomplished through a ship routing system that designates certain Areas to be Avoided. It could also be accomplished through IMO's adoption of Particularly Sensitive Sea Areas (PSSAs) subject to associated protection measures, including speed restrictions. These measures could include those listed in the Conflict Avoidance Agreement for approaching whales, ${ }^{524}$ marine mammal observers, ${ }^{525}$ and zones prohibiting certain types of waste discharge. ${ }^{526}$

Much of the Bering Strait Region could qualify for designation based

See Endangered and Threatened Species; Final Determination on a Petition to Designate Critical Habitat for the Bering Sea Stock of Bowhead Whales, 67 Fed. Reg. 55,767 (Aug. 30, 2002). This determination could change, however, if the habitat is demonstrated to be significantly degrading due to climate change and increased ship traffic.

522. Section 7(a)(2) of the Endangered Species Act requires federal agencies to "insure that any action authorized, funded, or carried out by such agency . . . is not likely to jeopardize the continued existence of any endangered species or threatened species or result in the adverse modification of habitat of such species . . . determined . . to be critical . ..." 16 U.S.C. $\S 1536(a)(2)$ (1988) (alterations added); see also 50 C.F.R. $\S 402.14(a)$ (2013) (discussing the consultation requirement).

523. See NOAA, Endangered and Threatened Species: Designation of Critical Habitat for Cook Inlet Beluga Whale, Final rule, 76 Fed. Reg. 20179 (Apr. 11, 2011).

524. The rules could integrate Conflict Avoidance Agreement measures prescribed for vessels approaching a whale, including reducing vessel speed to less than 5 knots within 900 feet of whales; steering around whales if possible; operating vessels in a manner that avoids separating a group of whales; operating vessels to avoid causing a whale to make multiple changes in direction; and checking the waters immediately adjacent to vessels to ensure that no whales will be injured when the propellers are engaged. See CAA, supra note 26, $\S \S$ 302(e), 501(d).

525. Legal authority for requiring marine mammal observers is less clear than authority for speed restrictions to avoid whales, which have already been put into place in the Atlantic Whale Reporting System. A possible source of authority could be COLREGs Rule 5, which requires that every vessel maintain a proper look-out by sight, hearing, and other means at all times, so as to make a full appraisal of the situation and the risk of collision. Navigation Rules Online: Rule 5-Lookout, United StATES COAST GuARD, http://www.navcen.uscg.gov/?pageName=navRulesContent\#rule5 (last visited Feb. 15, 2014, archived at http://perma.cc/K3UE-E83K).

526. PSSA Guidelines, supra note $353, \S 6.1 .1$ (listing as a possible associated protective measure the designation of a Special Area under MARPOL Annexes I, II, V, and VI or application of special discharge restrictions to vessels operating in a PSSA). Camden Bay (along the Beaufort Sea) is an example of a voluntary pollution avoidance zone created by the Conflict Avoidance Agreement, which requires exploratory drilling and production in a certain part of Camden Bay to prevent discharge of "drilling fluids, cuttings after 20" casing, treated sanitary and gray water, and ballast and bilge water." CAA, supra note $26, \S 503$ (a). 
on the area's ecological characteristics; its vulnerability due to environmental changes and increased traffic; and the navigational challenges associated with the area's ice, weather, and remoteness. ${ }^{527}$ The importance of the area for traditional subsistence activities is another potentially qualifying factor. ${ }^{528}$ The United States' designation of the Bering Land Bridge as a national preserve ${ }^{529}$ and the 2012 United StatesRussian Joint Statement Pursuing a Transboundary Area of Shared Beringian Heritage lend further support to the area's unique environmental characteristics. ${ }^{530}$ The Bering Strait's status as an international strait should not prevent a PSSA designation, given that parts of another international strait, the Torres Strait, have already obtained PSSA designation. ${ }^{531}$

Determining which areas should be avoided or subject to protective measures requires consultation with a variety of stakeholders. The US National Marine Fisheries Service (NMFS) and its Russian counterpart should characterize the occurrence, movements, and seasonality of marine mammals and their potential vulnerability to impacts associated with vessel traffic. The US Coast Guard will need to consult with NMFS and the Fish and Wildlife Service pursuant to section 7 of the Endangered Species $\mathrm{Act}^{532}$ to determine actions needed to protect species subject to the Act. Consultation also needs to take place with Alaska Native communities

527. Hartsig et al., supra note 1, at 38. Several international groups have already identified ecological and biological significant areas in the Bering Straits that could be designated as PSSAs. NOME WORKSHOP REPORT, supra note 3, at 4; see also NRDC, Workshop to IDENTIFy AREAS OF ECOlOGiCAL AND BiologicAl Significance OR VULNERABILITY IN THE ARCTIC MARINE ENVIRONMENT (2010), archived at http://perma.cc/W5DK-WL3K (concluding that the Bering Strait meets all seven of the Convention on Biological Diversity's criteria for ecologically and biologically significant areas).

528. See Nome Workshop Report, supra note 3, at 7 (describing subsistence use of the region); Hartsig et al., supra note 1 , at 5 .

529. The United States designated a portion of Seward Peninsula as a national preserve, the Bering Land Bridge National Preserve, in 1980. See What is Beringia?, NATIONAL PARK SERVICE, http://www.nps.gov/bela/historyculture/beringia.htm (last visited Nov. 17, 2013, archived at $\mathrm{http}: / /$ perma.cc/L9G2-S9V9).

530. The statement aims to establish a transboundary protected area linking the Bering Land Bridge National Preserve with a national park on the Russian side. See U.S. and Russia Link Parks Across Bering Strait, Environment News Service (Sept. 10, 2012), http://ensnewswire.com/2012/09/10/u-s-and-russia-link-parks-across-bering-strait/, archived at http://perma.cc/9JZ9-ENSY.

531. See supra Section 3.1 on the Torres Strait.

532. Section 7(a)(2) of the Endangered Species Act requires federal agencies to: insure that any action authorized, funded, or carried out by such agency . . . is not likely to jeopardize the continued existence of any endangered species or threatened species or result in the adverse modification of habitat of such species . . . determined . . . to be critical . . . .

16 U.S.C. $\S 1536(a)(2)(2012) ; 50$ C.F.R. $§ 402.14(a)$ (May 4, 2009) (outlining consultation procedures). 
bordering the Bering Strait, ${ }^{533}$ Alaska Native Organizations (including the Alaska Eskimo Whaling Commission), and the Alaska Department of Fish and Game to identify and characterize the species, seasons, and areas in which traditional marine mammal subsistence activities occur. ${ }^{534}$

An additional source of information on sensitive areas is the Bering Sea Sub Network (BSSN), which is composed of both Russian and Alaskan members. ${ }^{535}$ BSSN has been mapping sensitive, high-density subsistence areas based on consultations with local hunters, who draw their subsistence hunting areas on a map. ${ }^{536}$ Using this information, BSSN has compiled a map of the areas most heavily used for subsistence. ${ }^{537}$

\subsubsection{Ice Patrol}

In cooperation with Russia and other countries, the United States could establish an ice patrol similar to the one that currently takes place near Newfoundland. This would likely not happen until there is a significant increase in vessel traffic and accident risk and the US Coast Guard invests in the needed infrastructure.

\subsubsection{Marine Pilotage}

Alaska's compulsory marine pilotage laws could be extended to maximize the state's jurisdiction under federal law. Alaska could impose a compulsory pilot requirement extending beyond state waters if applied to vessels bound for or departing from an Alaskan port. ${ }^{538}$

533. The US Coast Guard is obligated to work on a government-to-government basis with Alaska Native Tribal governments as a part of the government's trust responsibilities. Exec. Order No. 13,175, 65 Fed. Reg. 67,249 (Nov. 9, 2000). The consultation requirement was extended to Alaska Native Corporations by a 2004 appropriations act. See Consolidated Appropriations Act, Pub L. 108-199, Div. H §161, 118 Stat. 3, 452 (2004), as amended by Consolidated Appropriations Act, Pub L. 108-447, Div. H, Title V, §518, 118 Stat. 2809, 3267 (2005).

534. Consultation with these stakeholders should take place regardless of what system is considered for implementation.

535. Cooper, supra note 48 , at 6 .There are other non-profit and native groups working on mapping sensitive areas, including the Bering Sea Elders Group. See Our Work, Bering SEA ELDERS GROUP, http://www.beringseaelders.org/our-work (last visited Nov. 17, 2013, archived at http://perma.cc/DXM8-X2MG).

536. Cooper, supra note 48, at 6.

537. Cooper, supra note 48, at 6 .

538. The federal grant of state authority over pilotage generally extends to pilotage in the "bays, rivers, harbors and ports of the United States," 46 U.S.C. §8501(a) (2013), and there is clear state authority for pilotage in connection with deep-water ports in state territorial waters. 33 U.S.C. $\S \S 1501,1518(\mathrm{a})(2)$. A State can assert its pilotage authority and extend its compulsory pilotage waters as far from its coastline as the state reasonably believes is necessary to achieve the objectives of its compulsory pilotage system. See, e.g., Gillis v. La., 


\section{CONCLUSION}

International and US law provide for a variety of systems that could be used separately or in tandem to regulate the Bering Strait Region. Since international law limits the United States' ability to unilaterally regulate the Bering Strait, and since wildlife is not aware of international boundaries, the United States should strive to work with Russia to obtain an IMOapproved system. Ideally, a ship reporting system along with routing measures, more navigational aids, special and protected areas, a vessel traffic service, and a tracking system could be implemented for the region. Even if agreement with Russia and IMO cannot be reached, the United States could implement a voluntary system. On a smaller scale, the implementation of a simple, VHF-based ship reporting system coordinated with the existing AEWC system would be relatively cost-effective. The designation of a PSSA could also be cost-effective and relatively simple to justify, although the effectiveness would be lower if the United States did not increase its presence in the area. As traffic increases, improving ship communications will be essential to avoid shipping accidents and marine mammal collisions and protect the resources that make the Bering Strait Region so unique.

294 F. 3rd 755 (5th Cir. 2002) (holding that the geographic reach of a state's pilotage jurisdiction is neither limited to three miles nor preempted by federal law); Warner v. Dunlap, 532 F.2d 767, 772 (1st Cir. 1976) (holding that States can establish and enforce their own compulsory pilotage regulations and requirements "at distances considerably greater than three miles from their shores"-as far from their coast as is necessary to "promote navigational safety and to protect the environmental integrity of their coastlines (from, e.g., oil spills caused by tankers running aground) by regulating pilotage . . ..”) (alteration added); Wilson v. McNamee, 102 U.S. 572, 573-574 (1881) (recognizing a State's authority to establish pilotage requirements out to at least "fifty miles from port"); ROBERT FORCE, AdMIRALTY AND MARITIME LAW 150-151 (2004) ("Wide latitude is given to the states in determining the waters in which a vessel must procure a state-licensed pilot.") Still, there are limitations. A State cannot require pilotage of a coastwise vessel (one not entering or leaving a port) if the vessel is at least 500 tons and is a tanker, freight vessel, bulk freight vessel, high speed freight vessel, or self-propelled mobile offshore drilling unit; engaged in a foreign voyage. 46 U.S.C. $\S 8501$ (d) (exclusions from state jurisdiction); 46 U.S.C. $\S \S 8502$, 3202, 3702 (vessels subject to federal pilotage). 
APPENDIX 1: COMPARISON OF SYSTEMS USED TO REGULATE SHIPS

\begin{tabular}{|c|c|c|c|c|c|}
\hline $\begin{array}{l}\text { Type } \\
\text { of System }\end{array}$ & $\begin{array}{l}\text { Ship } \\
\text { Reporting } \\
\text { System }\end{array}$ & $\begin{array}{l}\text { Ship Routing } \\
\text { System }\end{array}$ & $\begin{array}{l}\text { Vessel Traffic } \\
\text { Service }\end{array}$ & $\begin{array}{l}\text { Long Range } \\
\text { Tracking }\end{array}$ & $\begin{array}{l}\text { Automatic } \\
\text { Identification } \\
\text { System }\end{array}$ \\
\hline $\begin{array}{l}\text { Vessels } \\
\text { subject to } \\
\text { system }\end{array}$ & $\begin{array}{l}\text { Depends on } \\
\text { system; may } \\
\text { be mandatory } \\
\text { for some or all } \\
\text { vessels from } \\
\text { all flag states } \\
\text { subject to } \\
\text { SOLAS }\end{array}$ & $\begin{array}{l}\text { Depends on } \\
\text { system; may } \\
\text { be mandatory } \\
\text { for some or } \\
\text { all vessels } \\
\text { from all flag } \\
\text { states subject } \\
\text { to SOLAS }\end{array}$ & $\begin{array}{l}\text { Depends on } \\
\text { system; may be } \\
\text { mandatory for } \\
\text { some or all } \\
\text { vessels }\end{array}$ & $\begin{array}{l}\text { Required } \\
\text { under SOLAS } \\
\text { and US law } \\
\text { for cargo } \\
\text { vessels of } 300 \\
\text { gross tons or } \\
\text { more, } \\
\text { passenger } \\
\text { ships, high } \\
\text { speed craft, } \\
\text { and mobile } \\
\text { offshore } \\
\text { drilling rigs }\end{array}$ & $\begin{array}{l}\text { Required under } \\
\text { SOLAS for all } \\
\text { passenger } \\
\text { vessels, all } \\
\text { vessels of } 300 \\
\text { gross tons and } \\
\text { larger on } \\
\text { international } \\
\text { voyages, and } \\
\text { all cargo } \\
\text { vessels of } 500 \\
\text { gross tons not } \\
\text { on international } \\
\text { voyages; } \\
\text { required under } \\
\text { US law for } \\
\text { commercial } \\
\text { vessels } 65 \text { feet } \\
\text { or longer, } \\
\text { passenger } \\
\text { vessels of } 150 \\
\text { tons or more, } \\
\text { and all tankers, } \\
\text { either on } \\
\text { international } \\
\text { voyages or in } \\
\text { VTS areas }\end{array}$ \\
\hline
\end{tabular}




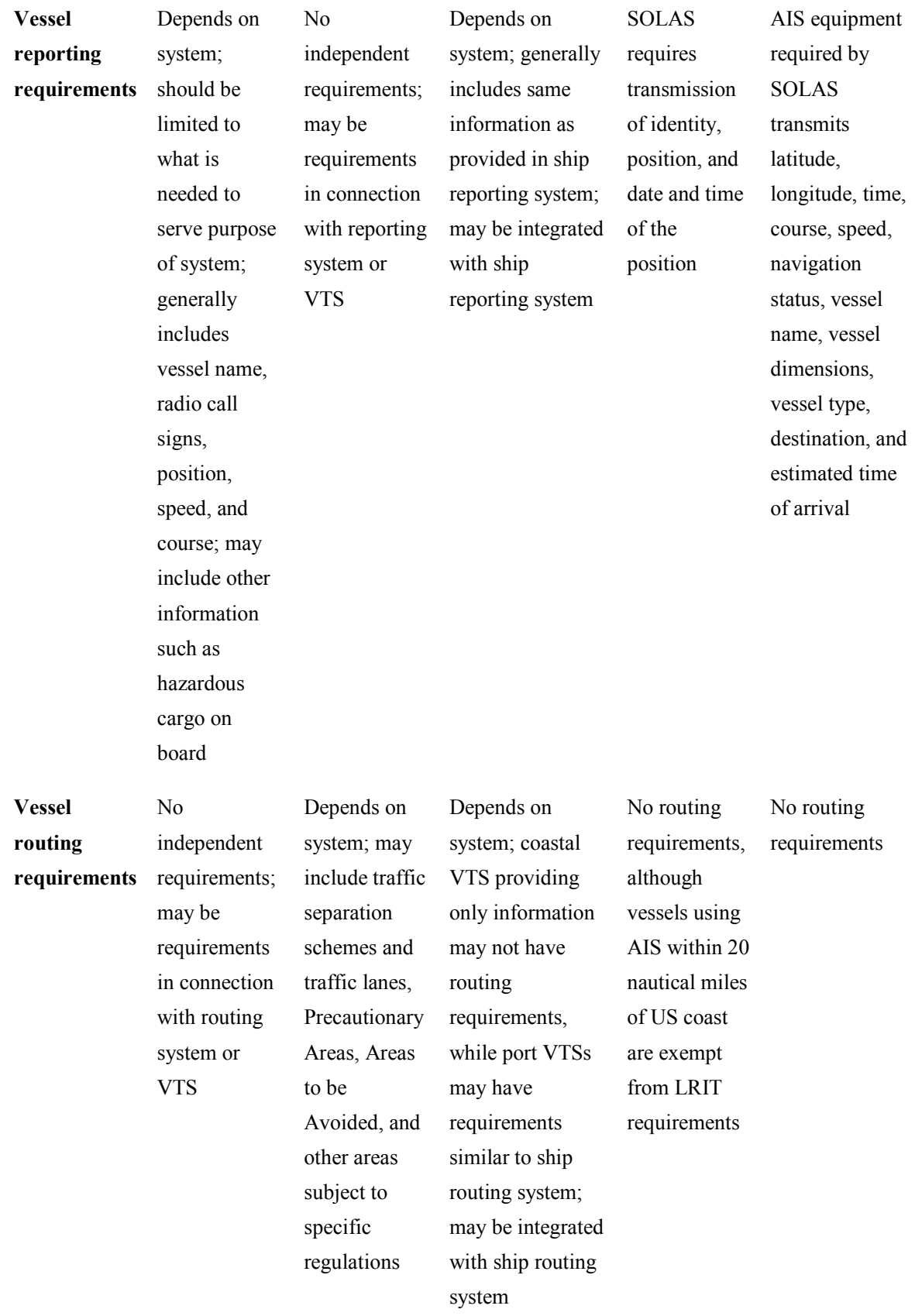




\begin{tabular}{|c|c|c|c|c|c|}
\hline $\begin{array}{l}\text { Receiver } \\
\text { information } \\
\text { provided }\end{array}$ & $\begin{array}{l}\text { Depends on } \\
\text { system; } \\
\text { generally } \\
\text { navigational/ } \\
\text { safety } \\
\text { information } \\
\text { provided }\end{array}$ & $\begin{array}{l}\text { No } \\
\text { independent } \\
\text { requirements; } \\
\text { information } \\
\text { may be } \\
\text { provided in } \\
\text { connection } \\
\text { with reporting } \\
\text { system or } \\
\text { VTS }\end{array}$ & $\begin{array}{l}\text { Depends on } \\
\text { system; generally } \\
\text { includes same } \\
\text { information as } \\
\text { provided in ship } \\
\text { reporting system }\end{array}$ & $\begin{array}{l}\text { No } \\
\text { independent } \\
\text { requirements; } \\
\text { information } \\
\text { may be } \\
\text { provided in } \\
\text { connection } \\
\text { with reporting } \\
\text { system or } \\
\text { VTS }\end{array}$ & $\begin{array}{l}\text { No independent } \\
\text { requirements; } \\
\text { information } \\
\text { may be } \\
\text { provided in } \\
\text { connection with } \\
\text { reporting } \\
\text { system or VTS }\end{array}$ \\
\hline $\begin{array}{l}\text { Areas in } \\
\text { effect }\end{array}$ & $\begin{array}{l}\text { Wherever } \\
\text { system is } \\
\text { approved by } \\
\text { IMO, which } \\
\text { could be in } \\
\text { any marine } \\
\text { area }\end{array}$ & $\begin{array}{l}\text { Wherever } \\
\text { system is } \\
\text { approved by } \\
\text { IMO, which } \\
\text { could be in } \\
\text { any marine } \\
\text { area }\end{array}$ & $\begin{array}{l}\text { SOLAS allows } \\
\text { stand-alone } \\
\text { mandatory VTSs } \\
\text { only in territorial } \\
\text { waters, but VTS } \\
\text { could take place } \\
\text { beyond territorial } \\
\text { waters if } \\
\text { voluntary or part } \\
\text { of an IMO- } \\
\text { approved } \\
\text { routing/reporting } \\
\text { system }\end{array}$ & $\begin{array}{l}\text { Range is at } \\
\text { least } 1,000 \\
\text { nautical } \\
\text { miles; } \\
\text { foreign- } \\
\text { flagged ships } \\
\text { must report to } \\
\text { US before } \\
\text { entering port } \\
\text { or when } \\
\text { within } 1,000 \\
\text { nautical miles } \\
\text { of US }\end{array}$ & $\begin{array}{l}\text { Standard AIS } \\
\text { has limited } \\
\text { horizontal } \\
\text { range (out to } 35 \\
\text { nautical miles); } \\
\text { satellite-based } \\
\text { AIS being } \\
\text { developed with } \\
\text { greater range; } \\
\text { generally used } \\
\text { in coastal areas }\end{array}$ \\
\hline
\end{tabular}




\begin{tabular}{|c|c|c|c|c|c|}
\hline $\begin{array}{l}\text { Approval } \\
\text { requirements }\end{array}$ & $\begin{array}{l}\text { To enforce } \\
\text { against vessels } \\
\text { from all } \\
\text { SOLAS states, } \\
\text { affected } \\
\text { coastal states } \\
\text { must submit } \\
\text { joint proposal } \\
\text { to IMO }\end{array}$ & $\begin{array}{l}\text { To enforce } \\
\text { against } \\
\text { vessels from } \\
\text { all SOLAS } \\
\text { states, } \\
\text { affected } \\
\text { coastal states } \\
\text { must submit } \\
\text { joint proposal } \\
\text { to IMO }\end{array}$ & $\begin{array}{l}\text { If within } \\
\text { territorial waters, } \\
\text { no IMO approval } \\
\text { needed; but state } \\
\text { should be able to } \\
\text { demonstrate that } \\
\text { service is } \\
\text { warranted by } \\
\text { level of traffic or } \\
\text { risk and } \\
\text { consistent with } \\
\text { international law; } \\
\text { VTS could be } \\
\text { approved by IMO } \\
\text { in international } \\
\text { strait in } \\
\text { connection with } \\
\text { ship reporting/ } \\
\text { routing system }\end{array}$ & $\begin{array}{l}\text { Already } \\
\text { required by } \\
\text { IMO, so state } \\
\text { does not need } \\
\text { IMO approval } \\
\text { to use }\end{array}$ & $\begin{array}{l}\text { Already } \\
\text { required by } \\
\text { IMO, so state } \\
\text { does not need } \\
\text { IMO approval } \\
\text { to use }\end{array}$ \\
\hline
\end{tabular}




\section{APPENDIX 2: OUTLINE OF POSSIBLE SHIP REPORTING SYSTEM FOR BERING STRAIT REGION}

A mandatory reporting system for ships in the Bering Strait Region (BERING) is established.

1. Ships required to take part in the system include all of the following, except sovereign immune vessels which are exempt from reporting by SOLAS regulation $\mathrm{V} / 8-1(\mathrm{c})$ :

1.1. All ships of 50 meters or greater in overall length; ${ }^{539}$

1.2. All ships, regardless of length, carrying in bulk hazardous and/or potentially polluting cargo, including at least 10,000 gallons of fuel or other oil product, in accordance with the definitions at resolution MSC.43(64), paragraph $1.4{ }^{540}$ and

1.3. All ships of 300 gross tonnage or greater. ${ }^{541}$

All other ships are recommended to participate in BERING. ${ }^{542}$

2. Geographical limits of the BERING reporting area. ${ }^{543}$ The reporting area consists of the marine area between North America and Asia from roughly $63^{\circ}$ and $69^{\circ}$ north latitude, including the northern Bering Sea, the Bering Strait, and the southern Chukchi Sea.

3. Format and content of reports, time and geographical position for submitting reports, authority to which they must be sent, and available services.

3.1. Format. The reporting format must be consistent with IMO Resolution A.851(20).

3.2. Content. Ships are required to provide the following

539. See Torres Strait Reporting System, supra note 209, $₫ 1$.

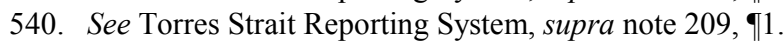

541. See Atlantic Whale Reporting System, supra note 201, $₫ 1$.

542. If BERING is integrated with the Conflict Avoidance Agreement, Paragraph 1 could be expanded to provide for three classes of reporting vessels - (1) those described in the language provided in the current Paragraphs 1.1-1.3; (2) subsistence fishing and whaling boats; and (3) all other vessels. The reporting requirements detailed in this appendix would apply only to vessels in the first category. Subsistence fishing and whaling boats would have unique reporting requirements based on the Conflict Avoidance Agreement. For example, whaling captains would be required to report to a communication center when they launch their boats from shore and again when they return shore. See CAA, supra note 26, § 202(b). They would report their whaling camp location, boat location, general direction of travel, plans for the following day, and any industry vessels not observing the agreement's guidelines. See CAA, supra note 26, § 202(b). For all other vessels, reporting would be voluntary.

543. This language covers the entire Bering Strait Region, as the term is used in this paper. The language could be modified to cover only the strait itself, or just particularly sensitive sea areas, if established. Or it could be possibly expanded to cover the entire Bering Sea, if justified by the volume of traffic. The Galapagos Islands system covers PSSAs, while the Atlantic Whale Reporting System consists of two areas frequented by whales but not established as PSSAs. Atlantic Whale Reporting System, supra note 201. 
information: the name of the ship; call sign or IMO identification number, if applicable; position when entering the system; course; speed; route; and destination. ${ }^{544}$ Ships must also report when they are deviating from a route or port previously reported due to weather conditions, damaged equipment, or other reasons. ${ }^{545}$ Ships are requested to provide information on the geographic coordinates of any bowhead whales sighted, and any potentially hazardous ice or weather conditions. ${ }^{546}$ Commercially sensitive information received in conjunction with the reporting system shall be kept confidential. $^{547}$

3.3. Time and geographical position for submitting reports. At all times during the year, ${ }^{548}$ participating ships are required to report to a shore-based when entering the reporting area. ${ }^{549}$

3.4. Authority receiving report. BERING reports must be sent to

544. E.g., Atlantic Whale Reporting System, supra note 201, $\{3.2$. If one of the stated purposes of BERING is to integrate with the Conflict Avoidance Agreement, it is possible that ships could also be required to report the ships' operator and owner; the oil and gas project the vessel is working on (if any); and plans for vessel movement between the time of the call and the time of the next call. See CAA, supra note 26, § 202(a) (detailing information to be reported).

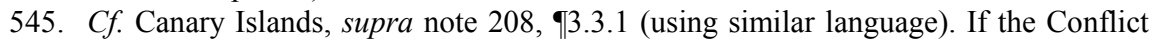
Avoidance Agreement is integrated into BERING, vessels in the area for the purpose of conducting oil and gas operations could also be required to report a change in plans related to drilling or seismic operations. See CAA, supra note $26, \S 202(\mathrm{a})(2)$.

546. The Atlantic Whale Reporting System makes reporting on whales voluntary: it says that "mariners will also be requested to report any whale sightings and dead, injured, or entangled marine mammals to the nearest local Coast Guard station." Atlantic Whale Reporting System, supra note 201, 94.4. It may be easier to make this aspect of reporting voluntary, given the resistance to ship routing systems for whale protection. $C f$. SOLAS Guidelines, supra note 101, $\S 6.2 .2$ ("The report required should be limited to information essential to achieve the objectives of the system."). If the system is integrated with the Conflict Avoidance Agreement, ships could be required or requested to report information on whales by VHF voice call using the same radio channels listed in the Conflict Avoidance Agreement. See CAA, supra note 26, §§ 202(c), 205(a-b).

547. See Atlantic Whale Reporting System, supra note 201, \3.2.

548. Depending on what area is subject to the reporting system, this description could be modified. For example, if only the Bering Strait itself will be covered, reporting could be limited to the periods in spring and fall when bowhead whales are passing through the strait. Reporting could be required throughout the year if the entire Bering Sea is covered.

549. This is similar to language in the Atlantic Whale Reporting System. Atlantic Whale Reporting System, supra note 201, $\{3.3$. Language in the Canary Island Reporting System is more complex, requiring reporting when ships deviate from route and leave from any port in the area. Supra note 208, $\{3.3$.

549. The language here could be adjusted to require reporting to occur a certain time prior to entry, or allow reporting to take place within a certain time after entry. For example, the Torres Strait Reporting System requires reporting six hours prior to entry. Torres Strait Reporting System, supra note 209, $\mid 6$. Ships could also be required to report when within five miles of certain coastal towns. 
the nearest Coast Guard station. ${ }^{550}$ Reporting may take place via InmarsatC, VHF-FM, or other method. ${ }^{551}$ Information received from the ships will be sent electronically to a central location for data storage, handling, and retrieval. ${ }^{552}$

3.5. Language. The language used for reports in the systems is English, using the IMO Standard Marine Communication Phrases where necessary. Standard phrases in a prescribed format will be used in all directprinting telegraphy and radiotelephony communications.

4. Information to be provided to participating ships and procedures to be observed. Mariners shall be informed that they are entering an area of critical importance for the protection of the bowhead whale or other species; that such whales or animals are present; and that ship strikes pose a serious threat to the animals and may cause damage to ships. ${ }^{553}$

4.1. The Coast Guard will provide ships with the following information, using the ship's broadcasting equipment: (a) information vital to weather and navigational safety in the ship's reporting area, including ice conditions, (b) geographic coordinates of recent whale sightings.

4.2. If necessary, any ship may ask for information on its own behalf about specific local conditions.

4.3. Mariners are advised to monitor Coast Guard Broadcast Notice to Mariners, NAVTEX, and NOAA Weather Radio, and to keep a continuous listening watch in the area.

5. Regulations in force in the area covered by the system. The United States has taken appropriate action to implement international conventions to which it is a party, including, where appropriate, adopting domestic legislation and promulgating regulations through domestic law. Relevant laws in force include domestic legislation and regulations to implement the International Convention on Collision Regulations, the Safety of Life at Sea

550. There is currently only one Coast Guard Station that is actually on the Bering Sea: the Unalaska Marine Safety Unit. See Units Located in the 17th District, UnITED STATES COAST GUARD, http://www.uscg.mil/d17/units.asp (last visited Nov. 17, 2013, archived at http://perma.cc/A4C8-LGAQ). If the Coast Guard does not want to set up new communication centers in the area, then it should consider working with the existing AEWC Communication Centers.

551. Other United States reporting systems use Inmarsat-C, although not all reporting systems use this technology and it may not be the best technology for the Bering Sea Region. The Great Belt Reporting System requires reports to be made through VHF voice transmissions, although it allows ships equipped with AIS to fulfill certain basic reporting requirements. Supra note 208, $\uparrow \uparrow \mid 3.1,7.4 .1$. BERING could require voice transmissions for reports on the condition and locations of whales.

552. See Atlantic Whale Reporting System, supra note 201, 97.2.

553. Cf. Atlantic Whale Reporting System, supra note 201, $₫ 4.1$ (comparing the language of the cited text to the language in the paper). If the system is integrated with the Conflict Avoidance Agreement, ships could also be informed of whaling or fishing activity in the area. 
Convention, the International Convention on the Prevention of Pollution from Ships, the International Convention on Oil Pollution Preparedness, Response and Co-operation, the Convention on the International Trade in Endangered Species of Wild Fauna and Flora, the International Convention for the Regulation of Whaling, and other treaties. Relevant domestic legislation includes the Ports and Waterways Safety Act, the Endangered Species Act, the Whaling Convention Act, the Marine Mammal Protection Act, the Marine Protection Resources and Sanctuaries Act, and a variety of other acts. ${ }^{554}$

6. Action to take in the event of a ship's non-compliance with system requirements. All possible means will be deployed to obtain the participation of the ships required to send in reports. Should these fail to materialize and the offending ship can be identified beyond doubt, the competent authorities in the relevant flag State will be informed with a view to their investigating the situation and possibly starting legal proceedings under their national legislation. BERING exists for the exchange of information, and does not confer additional powers to impose change in a ship's operations. The reporting system will be implemented in accordance with the provisions of SOLAS Convention and other relevant international instruments. ${ }^{555}$

554. See generally Atlantic Whale Reporting System, supra note 201, $\uparrow 6$ (showing that if any PSSA, compulsory pilotage rules, traffic separation schemes or other routing measures, actual or recommended speed limits, or Areas to be Avoided are adopted, they would be mentioned here).

555. Adding a disclaimer here such as "the reporting system will not constitute a basis for preventing the passage of a ship in transit through the reporting area" may help obtain approval of the system. As discussed in this paper, the United States would not be able to stop transit passage through an international strait. 


\section{APPENDIX 3: NAVIGATIONAL AIDS IN THE BERING STRAIT REGION}

List of Coast Guard Maintained Aids to Navigation in the Bering Strait and Northward

\begin{tabular}{|c|c|c|}
\hline Aid to Navigation & Structure & Operation \\
\hline Cape Espenberg Light & $\begin{array}{l}\text { Diamond-shaped beacon } \\
\text { on skeleton tower }\end{array}$ & $\begin{array}{l}\text { Maintained from July } 1 \\
\text { to November } 1\end{array}$ \\
\hline $\begin{array}{l}\text { Kotzebue Buoys (about } \\
8 \text {, marking the entrance } \\
\text { to Kotzebue) }\end{array}$ & $\begin{array}{l}\text { Diamond-shaped beacon } \\
\text { on skeleton tower }\end{array}$ & $\begin{array}{l}\text { Maintained from July } 1 \\
\text { to September } 20\end{array}$ \\
\hline Cape Deceit Light & $\begin{array}{l}\text { Diamond-shaped beacon } \\
\text { on skeleton tower }\end{array}$ & $\begin{array}{l}\text { Maintained from July } 1 \\
\text { to November } 1\end{array}$ \\
\hline $\begin{array}{l}\text { Riley Channel Entrance } \\
\text { Light }\end{array}$ & $\begin{array}{l}\text { Diamond-shaped beacon } \\
\text { on skeleton tower }\end{array}$ & $\begin{array}{l}\text { Maintained from July } 1 \\
\text { to November } 1\end{array}$ \\
\hline $\begin{array}{l}\text { Cominco Red Dog Front } \\
\text { Light }\end{array}$ & On pier & Private Aid \\
\hline $\begin{array}{l}\text { Cominco Red Dog Rear } \\
\text { Light }\end{array}$ & On tower & Private Aid \\
\hline Point Hope Light & $\begin{array}{l}\text { Diamond-shaped beacon } \\
\text { on skeleton tower }\end{array}$ & $\begin{array}{l}\text { (no information } \\
\text { provided) }\end{array}$ \\
\hline
\end{tabular}

The above list is taken from the portion of the Coast Guard's Light List that covers Nautical Chart 16005, Cape Prince of Wales to Point Barrow. ${ }^{556}$ As shown in the figure below, Chart 16005 covers the Bering Strait itself and some areas to the north. Chart 16006 covers the area southward, some of which would also be included in the Bering Strait Region.

556. U.S. Coast Guard, Light List Pacific Coast and Pacific Islands VI (2012), archived at $\mathrm{http}: / /$ perma.cc/PCS9-LNKD. 


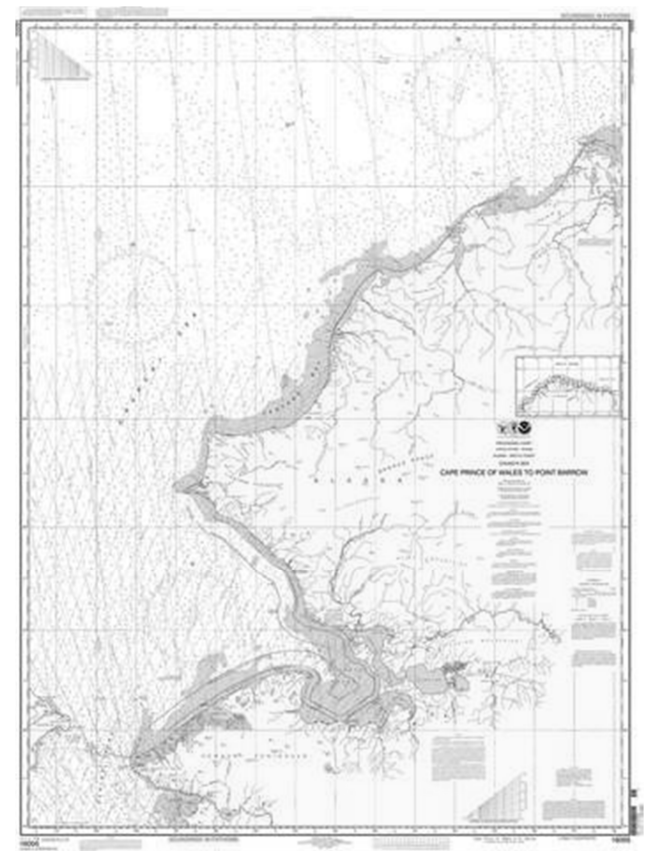

Figure: Chart 16005

Map of Buoys and Towers in and Near the Bering Strait Region Maintained by Other Entities

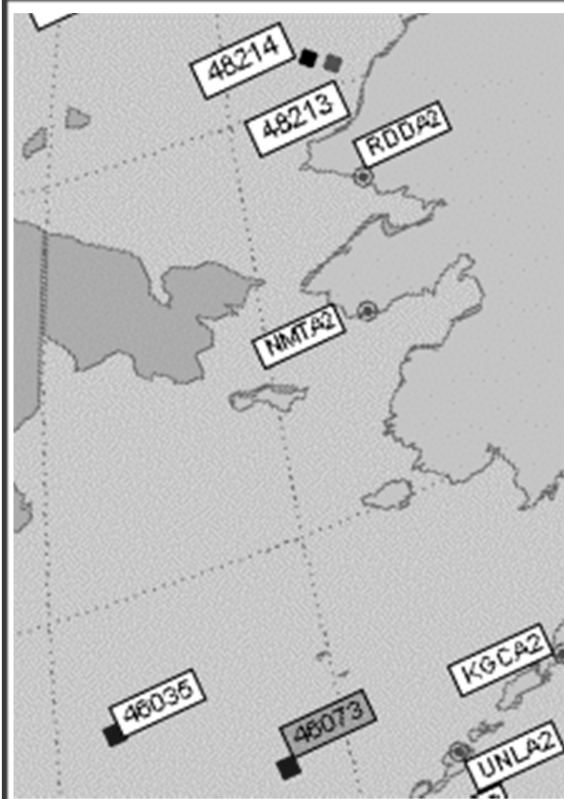

NMTA2 (Nome): Tower, owned and maintained by NOAA

RDDA2 (Red Dog): Tower, owned and maintained by NOAA

46035 (South Bering Sea): 12-meter discus buoy, owned and maintained by NOAA

$\mathbf{4 6 0 7 3}$ (South Bering Sea): 12-meter discus buoy, owned and maintained by NOAA, stopped transmitting Apr. 7, 2011

48213(Burger): Buoy at station owned and operated by Shell, not currently operating

48214 (Klondike): Buoy at station owned and operated by ConocoPhilips, not currently operating

KGCA2 (King Cove):Tower, owned and maintained by NOAA

UNLA2 (Unalaska):Tower, owned and maintained by NOAA

Source: NOAA National Buoy Data Center, www. ndbc.noaa.gov (Last Visited Nov. 15, 2012) 